This is a post-peer-review, pre-copyedit version of an article published in:

Woodward S., Dagorne S. (eds) Modern Organoaluminum Reagents. Topics in Organometallic Chemistry, vol 41. Springer, Berlin, Heidelberg, 2013, pp 59-90.

The final authenticated version is available online at: https://doi.org/10.1007/3418_2012_33

\title{
Organoaluminum complexes with bonds to s- block, p-block, d-block, and f-block metal centers
}

\author{
Stephan Schulz
}

\begin{abstract}
This chapter summarizes recent developments on organoaluminum compounds containing at least one direct bond between aluminum and an s-block, p-block, d-block or f-block metal center. General synthetic pathways to access such species are described along with their structural and bonding properties.
\end{abstract}

Keywords Aluminum, Molecular Intermetallics, Lewis acid, Lewis base, $\sigma$-Donor

$\begin{array}{ll}\text { Content } \\ 1 & \text { Introduction } \\ 2 & \text { Organoaluminum Complexes with s-Block Metals } \\ 3 & \text { Organoaluminum Complexes with p-Block Metals }\end{array}$

3.1 Organoaluminum Complexes with Group 13 Metals (Al, Ga, In, Tl)

3.2 Organoaluminum Complexes with Group 15 Metals (Sb, Bi)

3.3 Organoaluminum Complexes with other p-Block Metals ( $\mathrm{Sn}, \mathrm{Pb}, \mathrm{Te}$ )

4 Organoaluminum Complexes with d-Block Metals

5 Organoaluminum Complexes with f-Block Metals

6. Conclusions and Outlook

7. References

Stephan Schulz

Institute of Inorganic Chemistry, University of Duisburg-Essen, Universitätsstr. 5-7, D-45117

Essen, Germany

stephan.schulz@uni-due.de 


\section{Introduction}

Intermetallic complexes have a long standing history in organometallic chemistry not only due to their fascinating structural diversity but also to their interesting chemical properties. For instance, olefin polymerization reactions using titanium and aluminum complexes as reported by Ziegler and Natta claimed the presence of

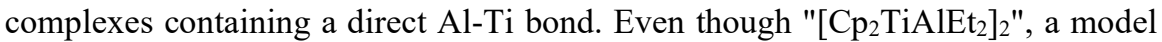
compound in the Ziegler-Natta olefin polymerization process, was later on shown to form no direct metal-metal bond, the interest in such complexes remained. Since these early studies, homo- and hetero-bimetallic complexes not only found technological applications in organic synthesis, polymerization catalysis, and were also shown to be very promising single source precursors for the deposition of thin films via metal organic chemical vapor deposition (MOCVD processes). These intermetallic materials (alloys) are also of technical interest since their electrical properties range from metallic to semiconducting (see, for instance, III/V and III/VI materials).

This chapter summarizes the synthesis and structures of intermetallic organoaluminum complexes exhibiting at least one direct bond between aluminum and either main group metals, transition metals, lanthanides or actinides. Homometallic aluminum complexes in lower oxidation states $\mathrm{I}(\mathrm{AlR})_{\mathrm{x}}$ and $\mathrm{II}\left(\mathrm{Al}_{2} \mathrm{R}_{4}\right)$ containing direct Al-Al bonds as well as metalloid cluster complexes are excluded from the present chapter and will be reviewed in Chapter 3. Likewise, the synthesis, structures and bonding properties of donor-acceptor complexes of alanediyls RAl with group 13 organometallics $\mathrm{R}_{3} \mathrm{M}(\mathrm{M}=\mathrm{A} 1, \mathrm{Ga}, \mathrm{In})$ are not described in the present contribution.

\section{Organoaluminum Complexes with s-Block Metals}

Organoaluminum complexes bound s-group metal centers have been predicted to be stable compounds by computational calculations [1], but alanediyl complexes of alkaline metals and earth alkaline metals remain unknown to date. In contrast, several gallane complexes have been prepared and structurally characterized [2-6]. Interestingly, dpp-BIAN complexes (dpp-BIAN $=1,2$-bis[2,6diisopropylphenyl)imino]-acenaphthene) of aluminum and gallium exhibit different coordination modes to alkali metals. While the Ga derivatives form direct Gametal bonds [2, 3], the aluminum analogues contain an alkaline metal binding to the $\pi$-electronic system of the dpp-BIAN ligand rather than to the Al center [7]. 


\section{Organoaluminum Complexes with p-Block Metals}

Heterobimetallic organoaluminum complexes with p-block metals, i.e. group $13(\mathrm{Ga}, \mathrm{In})$, group 15 ( $\mathrm{Sb}, \mathrm{Bi})$ and group 16 metals (Te), have been prepared to a large extent. The interest of such complexes does not only lie on their fundamental interest, i.e. the possible formation of Al-E ( $\mathrm{E}=\mathrm{p}$-block elements) complexes containing multiple bonds [8], but also on their potential usefullness in material science. Complexes of group 15 and group 16 metals, for instance, were shown to be promising single source precursors for the gas phase deposition of thin films as well as for solution-based synthetic routes to access (nanosized) semiconducting materials such as $\mathrm{AlSb}$ and $\mathrm{Al}_{2} \mathrm{Te}_{3}$.

\subsection{Organoaluminum Complexes with Group 13 Metals (Ga, In,} Tl)

Homo- and heterobimetallic organoaluminum complexes containing a direct $\mathrm{Al}-\mathrm{M}$ bond $(\mathrm{M}=\mathrm{Al}, \mathrm{Ga}, \mathrm{In})$ have attracted considerable attention within the last decade due to their interesting bonding properties. They are typically formed by reaction of strong Lewis acidic group 13 complexes M'R $_{3}$ with subvalent group 13 metal diyls $\mathrm{RM}(\mathrm{R}=\mathrm{Cp}$ *, nacnac, terphenyl), with the metal center $\mathrm{M}$ being in a $+\mathrm{I}$ formal oxidation state. Alanediyls RAl and their heavier congeners RM (M = $\mathrm{Ga}, \mathrm{In})$ exhibit a singlet electronic ground state with the singlet - triplet energy gap increasing with increasing atomic number. Group 13 diyls therefore behave as two-electron $\sigma$-donors, but also exhibit $\pi$-accepting properties as observed in isolobal fragments such as $\mathrm{CO}$, phosphanes $\mathrm{PR}_{3}$ and singlet carbenes $\mathrm{CR}_{2}$. The extent of $\sigma$-donation and $\pi$-acceptance largely depends on the nature of the metal and on the organic group $\mathrm{R}$, even though there is no simple correlation between the nature of the group 13 elements ( $M$ and $M^{\prime}$ ), the substituents $R, R^{\prime}$ and the stability of the complexes $R M-M^{\prime} R_{3}{ }^{\prime}$. However, the Lewis basicity ( $\sigma$-donor capacity) of group 13 diyls was found to be higher with increasing $\pi$-donor strength of the organic substituent $\mathrm{R}[9,10]$. As a consequence, strong $\pi$-donor ligands such as amido $\left(\mathrm{NR}_{2}\right)$ groups and the Cp* substituent enhance the stability of group 13-group 13 donor-acceptor complexes of the type RM-M'R' ${ }_{3}$ [11]. Simultaneously, the $\pi$ acceptor properties of the MR fragment is diminished according to the partial population of the vacant p-orbitals of the group 13 metal center through $\pi$ donation by the $\mathrm{Cp}^{*}$ substituents. Due to the lack of any back-bonding in intermetallic group 13 element complexes with direct bond to a main group metal, only the $\sigma$-donor properties of MR are of interest. In addition, computational calculations demonstrated that the metal-metal bond energies in the corresponding group 13 -transition metal complexes also primarily rely on the $\sigma$-donor properties of the group 13 diyls as well as on electrostatic contributions $[12,13]$. 
Lewis basic group 13 diyls were found to form stable adducts with group 13 Lewis acids. In particular, heteronuclear complexes containing the strong Lewis acid $\mathrm{B}\left(\mathrm{C}_{6} \mathrm{~F}_{5}\right)_{3}$, such as $\mathrm{Cp} * \mathrm{M}-\mathrm{B}\left(\mathrm{C}_{6} \mathrm{~F}_{5}\right)_{3}(\mathrm{M}=\mathrm{Al}[14]$, Ga $[15,16])$, NacnacM$\mathrm{B}\left(\mathrm{C}_{6} \mathrm{~F}_{5}\right)_{3}(\mathrm{Nacnac}=\beta$-diketiminato, $\mathrm{M}=\mathrm{Al}$ [17], $\mathrm{Ga}[16])$ and $\mathrm{R}^{\prime} \mathrm{M}-\mathrm{B}\left(\mathrm{C}_{6} \mathrm{~F}_{5}\right)_{3}(\mathrm{M}$ $=\mathrm{Ga}$, In; $\mathrm{R}^{\prime}=$ terphenyl) $[18,19]$, have been prepared and structurally characterized. The nature of the central $\mathrm{M}-\mathrm{B}$ bond in these complexes was investigated by computational calculations [12, 20, 21]. In addition, the homoleptic complexes $\mathrm{Cp}^{*} \mathrm{Al}-\mathrm{Al}\left(\mathrm{C}_{6} \mathrm{~F}_{5}\right)_{3}$ [22], $\mathrm{Cp} * \mathrm{Al}-\mathrm{Al}(t-\mathrm{Bu})_{3}$ [23], $\mathrm{Cp} * \mathrm{Ga}-\mathrm{Ga}(t-\mathrm{Bu})_{3}[15,23]$, and $\mathrm{Cp}^{*} \mathrm{Ga}-\mathrm{Ga}\left(\mathrm{Cp}^{*}\right) \mathrm{X}_{2}(\mathrm{X}=\mathrm{Cl}, \mathrm{I})[15]$ have also been synthesized. These complexes may alternatively be described as valence isomers of the corresponding divalent compounds $\mathrm{R}_{2} \mathrm{M}-\mathrm{MR}_{2}$. The nature of the supporting ligands subtly, yet clearly, influences the stability of the resulting complexes as demonstrated by computational calculations $[22,24]$.

Heteronuclear group 13 bimetallic complexes were formed either by reaction of alanediyls with group 13 Lewis acids $\left(\mathrm{Cp}^{*} \mathrm{Al}-\mathrm{Ga}(t-\mathrm{Bu})_{3}\right.$ [23]) or that of heavier group 13 diyls congeners with Lewis acidic alanes $\left(\mathrm{Cp}^{*} \mathrm{Ga}-\mathrm{Al}\left(\mathrm{C}_{6} \mathrm{~F}_{5}\right)_{3}\right.$ [25], $\mathrm{Cp}^{*} \mathrm{Ga}-\mathrm{Al}(t-\mathrm{Bu})_{3}[23], \mathrm{Cp} * \mathrm{In}-\mathrm{Al}(t-\mathrm{Bu})_{3}$ [23]) (Fig. 1).

$$
\begin{aligned}
1 / \mathrm{x}\left[\mathrm{Cp} \mathrm{p}^{*} \mathrm{M}\right]_{\mathrm{x}}+\mathrm{M}^{\prime}(t-\mathrm{Bu})_{3} & \longrightarrow \\
{\left[\mathrm{Cp}{ }^{*} \mathrm{M}\right]+\mathrm{Al}\left(\mathrm{C}_{6} \mathrm{~F}_{5}\right)_{3} } & \longrightarrow \mathrm{M}-\mathrm{Al}(t-\mathrm{Bu})_{3} \\
& \mathrm{Cp}^{*} \mathrm{M}-\mathrm{Al}\left(\mathrm{C}_{6} \mathrm{~F}_{5}\right)_{3} \\
& \mathrm{M}=\mathrm{Al}, \mathrm{Ga}, \mathrm{In} ; \mathrm{M}^{\prime}=\mathrm{Al}, \mathrm{Ga}
\end{aligned}
$$

Fig. 1 Synthesis of homo- and heteronuclear group 13-diyl complexes with group 13 Lewis acidic organometallics

\begin{tabular}{|c|c|c|c|c|}
\hline Adduct & Al-M & $\mathrm{M}-\mathrm{Cp}{ }^{*}$ centr. & $\mathrm{Cp}{ }^{*}-\mathrm{Al}-\mathrm{M}$ & Ref \\
\hline $\mathrm{Cp} * \mathrm{Al}$ & - & $2.015^{\mathrm{a}} / 2.063^{\mathrm{b}}$ & - & 26,27 \\
\hline $\mathrm{Cp} * \mathrm{Ga}$ & - & $2.081^{\mathrm{a}} / 2.081^{\mathrm{b}}$ & - & 28,29 \\
\hline $\mathrm{Cp}$ *In & - & $2.302^{\mathrm{a}} / 2.288^{\mathrm{b}}$ & - & 30 \\
\hline $\mathrm{Cp} * \mathrm{Al}-\mathrm{B}\left(\mathrm{C}_{6} \mathrm{~F}_{5}\right)_{3}$ & $2.169(3)$ & $1.802(3)$ & 172.9 & 14 \\
\hline NacnacAl-B $\left(\mathrm{C}_{6} \mathrm{~F}_{5}\right)_{3}$ & $2.183(5)$ & - & - & 17 \\
\hline $\mathrm{Cp} * \mathrm{Al}-\mathrm{B}\left(\mathrm{C}_{6} \mathrm{~F}_{5}\right) \mathrm{C}_{12} \mathrm{~F}_{8}$ & $2.1147(15)$ & 1.782 & 160.95 & 31 \\
\hline $\mathrm{Cp} * \mathrm{Al}-\mathrm{B}(\mathrm{Me}) \mathrm{C}_{12} \mathrm{~F}_{8}$ & $2.149(7)$ & $1.817 / 1.814$ & 162.76 & 31 \\
\hline $\mathrm{Cp} * \mathrm{Al}-\mathrm{B}(\mathrm{Ph}) \mathrm{C}_{12} \mathrm{H}_{8}$ & $2.1347(13)$ & 1.809 & 164.12 & 31 \\
\hline $\mathrm{Cp} * \mathrm{Al}-\mathrm{Al}(t-\mathrm{Bu})_{3}$ & $2.689(2)$ & 1.858 & 175.0 & 23 \\
\hline $\mathrm{Cp} * \mathrm{Ga}-\mathrm{Al}(t-\mathrm{Bu})_{3}$ & $2.629(2)$ & 1.913 & 174.2 & 23 \\
\hline $\mathrm{Cp} * \operatorname{In}-\mathrm{Al}(t-\mathrm{Bu})_{3}$ & $2.843(2)$ & 2.173 & 170.0 & 23 \\
\hline $\mathrm{Cp} * \mathrm{Al}-\mathrm{Ga}(t-\mathrm{Bu})_{3}$ & $2.620(2)$ & 1.861 & 175.5 & 23 \\
\hline $\mathrm{Cp} * \mathrm{Al}-\mathrm{Al}\left(\mathrm{C}_{6} \mathrm{~F}_{5}\right)_{3}$ & $2.591(2)$ & 1.810 & 170.1 & 22 \\
\hline
\end{tabular}

Table 1. Selected bond lengths $[\AA]$ and angles $\left[{ }^{\circ}\right]$ of homo- and heterobimetallic group 13 complexes 
$\begin{array}{ccccc}\mathrm{Cp}^{*} \mathrm{Ga}-\mathrm{Al}\left(\mathrm{C}_{6} \mathrm{~F}_{5}\right)_{3} & 2.515(11) & 1.810 & 170.6 & 25 \\ { }^{\mathrm{a}} \mathrm{As} \text { determined by single crystal X-ray diffraction for }[\mathrm{Cp} * \mathrm{Al}]_{4},[\mathrm{Cp} * \mathrm{Ga}]_{6} \text { and }[\mathrm{Cp} * \mathrm{In}]_{6} ;{ }^{\mathrm{b}} \mathrm{As} \text { de- }\end{array}$ termined by electron diffraction (gas phase) for the monomeric compounds $\mathrm{Cp} * \mathrm{M}$

Solid State Structures. Selected bond distances and angles for the group 13 complexes discussed above are provided in Table 1. In all these derivatives, the Cp* substituent in $\mathrm{Cp} * \mathrm{Al}-\mathrm{MR}_{3}$ and $\mathrm{Cp} * \mathrm{M}-\mathrm{AlR}_{3}\left(\mathrm{M}=\mathrm{Al}, \mathrm{Ga}\right.$, In) adopts a $\eta^{5}$ binding mode to the group 13 metal and the $\mathrm{Cp}^{*}$ centr $-\mathrm{M}-\mathrm{M}$ units slightly deviate from linearity. The $\mathrm{M}-\mathrm{Cp}^{*}{ }^{*}$ centr bond distances of the diyl adducts are significantly shorter than those in the group 13 diyl precursors $\mathrm{Cp} * \mathrm{M}$, as previously observed for heteronuclear complexes of the type $\mathrm{Cp}^{*} \mathrm{Al}-\mathrm{BR}_{3}$ [31]. Such a shortening results from the transformation of the partially antibonding electron lone pair of the diyl $\mathrm{Cp} * \mathrm{M}$ unit into a donor-acceptor bond upon coordination to $\mathrm{MR}_{3}$, along with the development of positive (donor-centered) and negative charges (acceptorcentered) at the group 13 metal centers [9].

The intermetallic $\mathrm{Al}-\mathrm{Al}$ and $\mathrm{Ga}-\mathrm{Al}$ bond lengths in $\mathrm{Cp} * \mathrm{M}-\mathrm{Al}(t-\mathrm{Bu})_{3}$ are shorter than the $\mathrm{In}-\mathrm{Al}$ bond length in $\mathrm{Cp} * \mathrm{In}-\mathrm{Al}(t-\mathrm{Bu})_{3}$ due to the increased atomic radius of In $v s$. those of $\mathrm{Al}$ and $\mathrm{Ga}$, respectively. Moreover, these intermetallic distances are significantly longer than those in $\mathrm{Cp} * \mathrm{M}-\mathrm{Al}\left(\mathrm{C}_{6} \mathrm{~F}_{5}\right)_{3}(\mathrm{M}=\mathrm{Al}, \mathrm{Ga})$, clearly reflecting the different electronic and steric properties of the $\mathrm{R}$ substituents in $\mathrm{AlR}_{3}$. The shortening of the M-M bond distance when going from Cp*Al-AlR to $\mathrm{Cp}^{*} \mathrm{Ga}-\mathrm{AlR}_{3}\left(\mathrm{R}=t\right.$ - $\left.\mathrm{Bu}, \mathrm{C}_{6} \mathrm{~F}_{5}\right)$ presumably results from stronger electrostatic repulsion in the $\mathrm{Al}-\mathrm{Al}$ derivative. Thus, upon complexation, the positive charge at the metal atom $\mathrm{M}(\mathrm{I})$ increases, with the $\mathrm{Al}$ metal donor featuring a larger positive charge compared to the $\mathrm{Ga}$ (metal donor) analogue [9]. Interestingly, structural data for NacnacAl- $-\mathrm{B}\left(\mathrm{C}_{6} \mathrm{~F}_{5}\right)_{3}(\mathrm{Nacnac}=\beta$-diketiminato, $\mathrm{M}=\mathrm{Al})[17]$ agree with the presence of an Al-B donor-acceptor interaction, as expected, along with weak $\mathrm{Al} \cdots \mathrm{F}$ interactions arising from close intramolecular contacts between one orthofluorine atom and the $\mathrm{Al}$ atom. Therefore, in such a complex, the Janus-type electronic properties of the $\mathrm{Al}$ center, a metal center behaving both as a Lewis acid and a Lewis base, is clearly evidenced.

Fig. 1 Solid state structure of $\mathrm{Cp} * \mathrm{Al}-\mathrm{Ga}(t-\mathrm{Bu})_{3}$ 


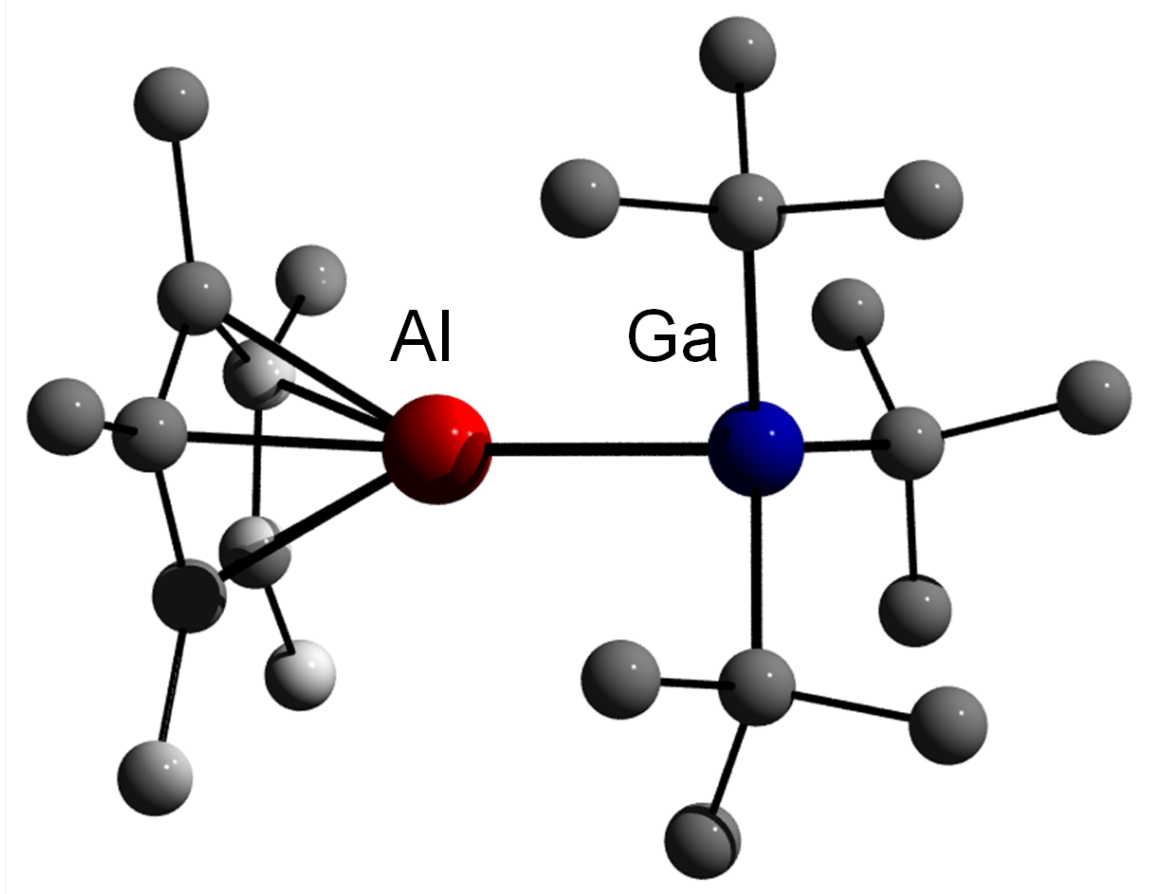

Fig. 3. Solid state structure of Cp*In- $\mathrm{Al}(t-\mathrm{Bu})_{3}$ 


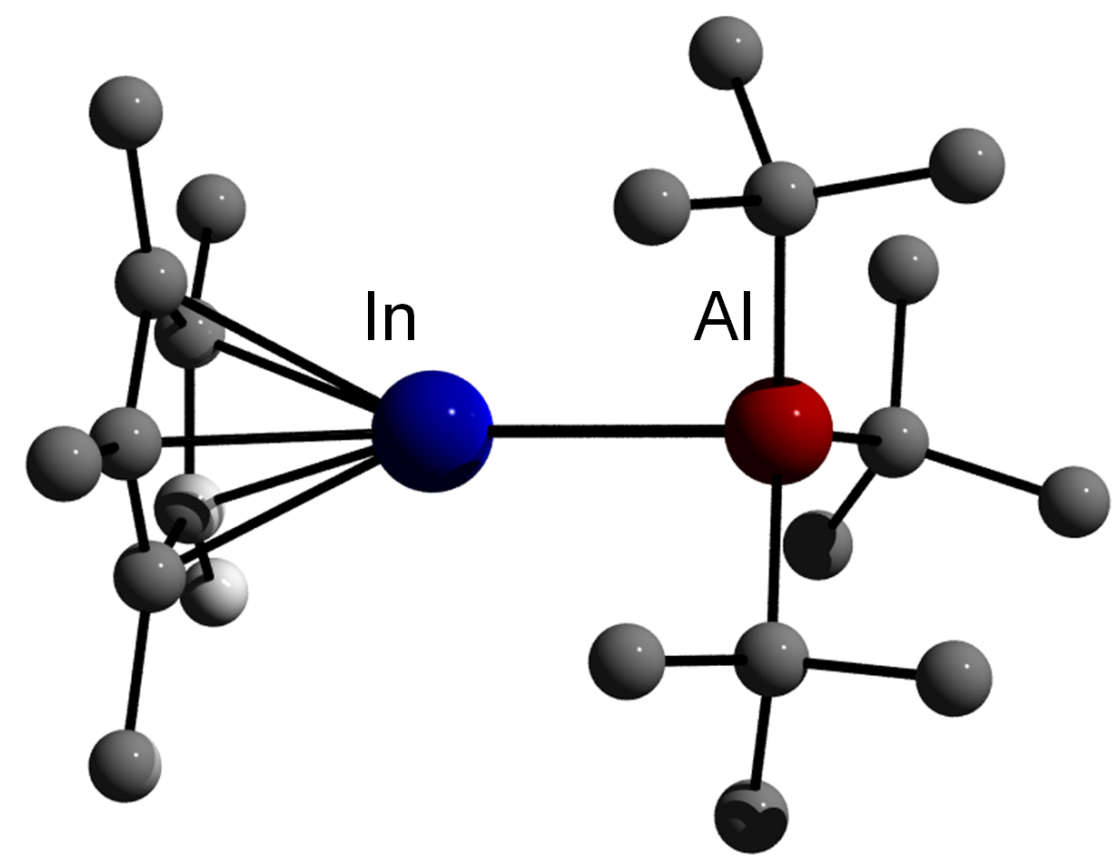

The Lewis basicity of group 13 diyls $\mathrm{Cp} * \mathrm{M}(\mathrm{M}=\mathrm{Al}, \mathrm{Ga})$ were investigated by comparing the deviation from planarity of the $\mathrm{BC}_{3}$ skeleton in $\mathrm{Cp} * \mathrm{M}-\mathrm{B}\left(\mathrm{C}_{6} \mathrm{~F}_{5}\right)_{3}$ complexes following a simple model described by Haaland et al. [32, 33]. According to this structural parameter, $\mathrm{Cp}^{*} \mathrm{Al}$ is slightly more Lewis basic than $\mathrm{Cp}^{*} \mathrm{Ga}$, as may be anticipated. Indeed, the basicity of analogously substituted Lewis bases typically decreases upon going down a given group in the Periodic Table. In fact, $\mathrm{Cp} * \mathrm{Al}$ was found to be nearly as Lewis basic as $\mathrm{PPh}_{3}$. Analogous trends were observed in complexes of the type $\mathrm{Cp} * \mathrm{M}-\mathrm{Al}(t-\mathrm{Bu})_{3}$ and $\mathrm{Cp}^{*} \mathrm{M}-\mathrm{Ga}(t-\mathrm{Bu})_{3}(\mathrm{M}=\mathrm{Al}$, Ga, In) [23].

\subsection{Organoaluminum Complexes with Group 15 Metals (Sb, Bi)}

Compounds containing group $13 / 15$ bonds have a long standing history in main group organometallic chemistry. Apart from their academic interest, such entities are also of interest as novel single source precursors for semiconducting III/V material films and nanoparticles via gas phase deposition (MOCVD process) [34-37].

Known for decades, the general reactivity patterns in group 13/15 chemistry have been studied by Wiberg and May. For instance, the reaction of $\mathrm{AlH}_{3}$ and $\mathrm{NH}_{3}$ initially yields a Lewis acid-base adduct $\mathrm{H}_{3} \mathrm{Al}-\mathrm{NH}_{3}$, which then further reacts at elevated temperatures with elimination of $\mathrm{H}_{2}$ to afford the stepwise and successive 
formation of aminoalane $\left[\mathrm{H}_{2} \mathrm{AlNH}_{2}\right]_{\mathrm{x}}$, iminoalane $[\mathrm{HAlNH}]_{\mathrm{x}}$ and aluminum nitride AlN as the final product [38] (Fig. 4).

Fig. 4. Reaction of $\mathrm{AlH}_{3}$ and $\mathrm{NH}_{3}$ with stepwise elemination of $\mathrm{H}_{2}$.

$$
\begin{aligned}
\mathrm{AlH}_{3}+\mathrm{NH}_{3} \longrightarrow & \mathrm{H}_{3} \mathrm{Al} \longrightarrow \mathrm{NH}_{3} \underset{-\mathrm{H}_{2}}{\longrightarrow}\left[\mathrm{H}_{2} \mathrm{AlNH}_{2}\right]_{x} \\
& \underset{-\mathrm{H}_{2}}{\longrightarrow}[\mathrm{HAINH}]_{x} \underset{-\mathrm{H}_{2}}{\longrightarrow} \text { AIN }
\end{aligned}
$$

Since these early studies, numerous compounds of the desired types have been prepared. However, the reaction pathway depicted in Fig. 4 only applies to the synthesis of organoaluminum complexes containing the lighter group 15 elements ( $\mathrm{N}, \mathrm{P}$, and As). In contrast, access to organoaluminum species of the heavier elements of group 15 , such as $\mathrm{Sb}$ and $\mathrm{Bi}$, was nearly unknown up to ten years ago. Nevertheless, ready access to such derivatives has been achieved over the past decade through the exploration and development of novel synthetic strategies.

\subsubsection{Lewis Acid-Base Adducts.}

The reaction between a Lewis acid group 13 species of the type $\mathrm{R}_{3} \mathrm{M}$ and a group 15 Lewis base of the type $\mathrm{ER}_{3}$ typically yields the corresponding Lewis acid-base adduct $\mathrm{R}_{3} \mathrm{M}-\mathrm{ER}_{3}$. This reaction, of fundamental interest in main group chemistry, has recently received an increased attention due to the potential use of amine-borane adducts as a hydrogen storage material [39] and to the unusual reactivity of so-called "Frustrated Lewis pairs" [40-42].

In contrast to well known alane-amine and alane-phosphine adducts, for which several general coordination geometries have been identified and whose stability, usually expressed by their dissociation enthalpies $\Delta H_{\text {Diss, }}$, has been determined experimentally in solution, in gas phase as well as by computational calculations [43], the corresponding stibine and bismuthine adducts have only been thoroughly investigated over the past few years [44]. Prior to these studies, the alane-stibine adduct, $\mathrm{Br}_{3} \mathrm{Al}-\mathrm{SbBr}_{3}$, a molecular adduct in the gas phase [45] but ionic in the solid state $\left(\left[\mathrm{SbBr}_{2}\right]\left[\mathrm{AlBr}_{4}\right]\right)[46]$, had been synthesized and structurally characterized. Yet, with an enthalpy of formation of $4.3 \pm 0.6 \mathrm{~kJ} \mathrm{~mol}^{-1}[47], \mathrm{Br}_{3} \mathrm{Al}-\mathrm{SbBr}_{3}$ is considered as a weakly bound Lewis acid-base adduct.

The low stability of the alane-stibine and -bismuthine adducts results from the reduced Lewis basicity of stibines and bismuthines due to the increasing scharacter of the electron lone pair on the group 15 element [48]. However, the Lewis basicity of $E^{\prime}{ }_{3}$ can be increased via the use of alkyl substituents with a strong electron-donor inductive effect. In addition, sterically demanding substituents, such as $i$-Pr and $t$-Bu, directly affect the Lewis basicity of stibines and bismuthines. Indeed, steric hindrance results in larger C-E-C bond angles thereby decreasing the $s$-character of the electron lone pair and increasing its $p$-character. 
Stable stibine-alane adducts are available by reaction of trialkylstibines $\mathrm{SbR}_{3}$ with dialkylchloroalanes $\mathrm{R}_{2} \mathrm{AlCl}$ [49] and trialkylalanes $\mathrm{AlR}_{3}$ [49-53], respectively. In addition, the first bismuthine-alane [54, 55], distibine-alane [53, 55-57], and dibismuthine-alane adducts [58] were prepared by reaction of $\mathrm{AlR}_{3}$ with $\mathrm{BiR}_{3}$, $\mathrm{Sb}_{2} \mathrm{R}_{4}^{\prime}$ and $\mathrm{Bi}_{2} \mathrm{Et}_{4}$, respectively, and subsequently structurally characterized. In most of these adducts the acid-base interaction in the gas phase and in solution is rather weak. Dissociation enthalpies of $t-\mathrm{Bu}_{3} \mathrm{Al}-\mathrm{E}(i-\mathrm{Pr})_{3}$ adducts $(\mathrm{E}=\mathrm{P} 12.2$ $\mathrm{kcal} / \mathrm{mol}$, As $9.9 \mathrm{kcal} / \mathrm{mol}$, Sb $7.8 \mathrm{kcal} / \mathrm{mol}$, Bi $6.9 \mathrm{kcal} / \mathrm{mol}$ ) [59], as determined by NMR in solution, steadily decrease, as expected, when going to heavier group 15 elements. Such a decrease in bond strength clearly reflects a lower Lewis basicity for heavier group 15 elements.

Fig. 5. Coordination modes observed for alane-stibine, distibine, -bismuthine and dibismuthine adducts<smiles>[R][Si]([R])([R])[Si]([R])([R])[R]</smiles><smiles>[R][Si]([R])([R])[Si]([R])([R])[R]</smiles>

$\mathrm{R}=\mathrm{alkyl}, \mathrm{R}^{\prime}=$ alkyl, $\mathrm{SiMe}_{3}$<smiles>[R][Si]([R])([R])[Si]([R])([R])[R]</smiles><smiles>[R][N+]([R])([R])[Sn]([R])([R])[Si]([R])([R])[R]</smiles><smiles>[R][N+]([R])([R])[Si]([R])([R])[Si]([R])([R])[R]</smiles>

$\mathrm{R}=t-\mathrm{Bu}, \mathrm{R}^{\prime}=$ alkyl

Table 2 summarizes important structural parameters for alane-stibine and bismuthine adducts $\mathrm{R}_{3} \mathrm{Al}-\mathrm{ER}_{3}{ }_{3}$ while Table 3 features those for distibines and dibismuthines precursors $\mathrm{R}_{2} \mathrm{E}-\mathrm{ER}_{2}{ }_{2}(\mathrm{E}=\mathrm{Sb}, \mathrm{Bi})$ and the corresponding alane adducts.

Table 2. Selected bond lengths $[\AA]$ and angles $\left[^{\circ}\right]$ of alane-stibine and alane-bismuthine adducts

\begin{tabular}{llllll}
\hline Adduct & M-E & Al-R (av) & $\Sigma$ X-E-X & $\Sigma \mathrm{R}-\mathrm{Al}-\mathrm{R}$ & Ref \\
\hline $\mathrm{R}_{3} \mathrm{Al}-\mathrm{Sb}\left(\mathrm{SiMe}_{3}\right)_{3}$ & & & & & \\
$\mathrm{R}=\mathrm{Et}$ & $2.841(1)$ & 1.984 & 310.8 & 347.3 & 49 \\
$\mathrm{R}=i-\mathrm{Bu}$ & $2.848(1)$ & 1.995 & 312.2 & 350.5 & 50
\end{tabular}

\section{$\mathrm{R}_{2} \mathrm{AlCl}-\mathrm{Sb}\left(\mathrm{SiMe}_{3}\right)_{3}$}




\begin{tabular}{llllll}
\hline $\mathrm{R}=t-\mathrm{Bu}^{*}$ & $2.821(1) ; 2.798(1)$ & $1.991 ; 1.994$ & $3.126 ; 3.091$ & $3.396 ; 3.415$ & 49 \\
$\mathrm{R}_{3} \mathrm{Al}-\mathrm{SbR}_{3}$ & & & & & \\
$\mathrm{R}=\mathrm{Me} ; \mathrm{R}^{\prime}=t-\mathrm{Bu}$ & $2.834(1)$ & 1.967 & 319.1 & 347.2 & 51 \\
$\mathrm{R}=\mathrm{Et} ; \mathrm{R}^{\prime}=t-\mathrm{Bu}$ & $2.873(1)$ & 1.981 & 317.8 & 343.7 & 51 \\
$\mathrm{R}=t-\mathrm{Bu} ; \mathrm{R}^{\prime}=\mathrm{Me}$ & $2.843(1)$ & 2.020 & 295.6 & 349.9 & 52 \\
$\mathrm{R}=t-\mathrm{Bu} ; \mathrm{R}^{\prime}=\mathrm{Et}$ & $2.845(1)$ & 2.027 & 301.5 & 346.9 & 51 \\
$\mathrm{R}=t-\mathrm{Bu} ; \mathrm{R}^{\prime}=i-\mathrm{Pr}$ & $2.927(1)$ & 2.030 & 294.1 & 348.7 & 51 \\
$\mathrm{R}=t-\mathrm{Bu} ; \mathrm{R}^{\prime}=i-\mathrm{Bu}$ & $2.903(2)$ & 2.019 & 302.4 & 347.2 & 53 \\
$\mathrm{R} 3 \mathrm{Al}-\mathrm{Bi}\left(\mathrm{SiMe}_{3}\right)_{3}$ & & & & & \\
$\mathrm{R}=\mathrm{Et}$ & $2.921(2)$ & 1.978 & 305.7 & 350.8 & 54 \\
$\mathrm{R}{ }_{3} \mathrm{Al}-\mathrm{BiR}{ }_{3}$ & & & & & \\
$\mathrm{R}=t-\mathrm{Bu} ; \mathrm{R}^{\prime}=\mathrm{Et}$ & $2.940(1)$ & 2.011 & 288.3 & 351.5 & 55 \\
$\mathrm{R}=t-\mathrm{Bu} ; \mathrm{R}^{\prime}=i-\mathrm{Pr}$ & $3.088(1)$ & 2.018 & 286.5 & 350.4 & 54 \\
\hline
\end{tabular}

* two molecules within the asymmetric unit

Table 3. Selected bond lengths $[\AA]$ and angles $\left[{ }^{\circ}\right]$ of alane-distibine and alane-dibismuthine adducts

\begin{tabular}{|c|c|c|c|c|c|c|c|}
\hline Adduct & E-E & Al-E & Al-C (av.) & E-C (av.) & $\Sigma Y-E-X^{a}$ & $\Sigma \mathrm{C}-\mathrm{Al}-\mathrm{C}$ & Ref \\
\hline \multicolumn{8}{|l|}{$\mathrm{E}_{2} \mathrm{R}_{4}$} \\
\hline $\mathrm{E}=\mathrm{Sb}, \mathrm{R}=\mathrm{Me}$ & $\begin{array}{l}2.862 \\
2.830(1) \\
2.838(1)\end{array}$ & - & - & $\begin{array}{l}2.15(2) \\
2.156\end{array}$ & \multicolumn{2}{|c|}{$285.4 ; 289.4$ - } & 60,61 \\
\hline $\mathrm{E}=\mathrm{Sb}, \mathrm{R}=\mathrm{Et}$ & $2.8381(5)$ & - & - & 2.170 & \multicolumn{2}{|c|}{$288.4 ; 287.6-$} & 56 \\
\hline $\begin{array}{l}\mathrm{E}=\mathrm{Bi}, \mathrm{R}=\mathrm{Et} \\
{\left[t-\mathrm{Bu}_{3} \mathrm{Al}\right]\left[\mathrm{E}_{2} \mathrm{R}_{4}\right]}\end{array}$ & $2.9827(7)$ & & & 2.291 & \multicolumn{2}{|l|}{281.8} & 56 \\
\hline $\begin{array}{l}\mathrm{E}=\mathrm{Sb}, \mathrm{R}=i-\mathrm{Pr} \\
{\left[t-\mathrm{Bu}_{3} \mathrm{Al}_{2}\left[\mathrm{E}_{2} \mathrm{R}_{4}\right]\right.}\end{array}$ & $2.855(1)$ & $3.003(2)$ & 2.029 & 2.196 & \multicolumn{2}{|c|}{$300.9 ; 288.2347 .4$} & 55 \\
\hline $\mathrm{E}=\mathrm{Sb}, \mathrm{R}=\mathrm{Me}$ & $2.811(1)$ & $2.919(1)$ & 2.020 & 2.146 & 295.1 & 351.1 & 57 \\
\hline $\mathrm{E}=\mathrm{Sb}, \mathrm{R}=\mathrm{Et}$ & $2.838(1)$ & $3.001(1)$ & 2.024 & 2.167 & 292.9 & 350.2 & 57 \\
\hline $\mathrm{E}=\mathrm{Sb}, \mathrm{R}=n-\mathrm{Pr}$ & $2.839(1)$ & $2.964(1)$ & 2.022 & 2.156 & 292.2 & 350.1 & 53 \\
\hline $\mathrm{E}=\mathrm{Bi}, \mathrm{R}=\mathrm{Et}$ & $2.983(1)$ & $3.084(2)$ & 2.016 & 2.283 & 287.7 & 352.7 & 58 \\
\hline
\end{tabular}

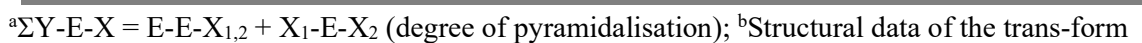

In alane-stibine and alane-bismuthine adducts $\mathrm{R}_{3} \mathrm{Al}-\mathrm{ER}_{3}$, both metal centers generally adopt a distorted tetrahedral coordination geometry with the organic substituents $\mathrm{R}$ and $\mathrm{R}^{\prime}$ oriented in a staggered conformation relative to one another.

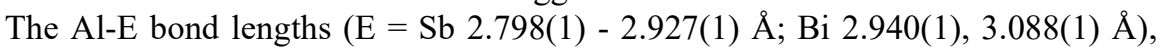
strongly dependent on the steric bulk of the organic substituents, are significantly elongated compared to the calculated single bond covalent radii ( $\sum r_{\operatorname{cov}}(\mathrm{AlSb}): 2.66$ $\AA$; $\Sigma r_{\text {cov }}(\mathrm{AlBi}): 2.77 \AA$ ) [62]. In contrast, $\mathrm{Br}_{3} \mathrm{Al}-\mathrm{SbBr}_{3}$ exhibits a significantly 
shorter Al-Sb bond length (2.522 $\AA$ ), less than the sum of the Al and Sb covalent radii.

The longest Al-E bond lengths have been observed for the severely crowded $t$ $\mathrm{Bu}_{3} \mathrm{Al}-\mathrm{E}(i-\mathrm{Pr})_{3}$ adducts. The Al-Bi bond lengths are much longer when compared to the Al-Sb bond lengths, a result of the larger atomic radius of $\mathrm{Bi}$. However, the observed difference in $t$ - $\mathrm{Bu} 3 \mathrm{Al}-\mathrm{E}(i-\mathrm{Pr})_{3}(\mathrm{E}=\mathrm{Sb} 2.927(1)$; Bi 3.088(1) $\AA$ ) exceeds that of their covalent radii ( $\mathrm{Sb}: 1.40, \mathrm{Bi}: 1.51 \AA)$.

Fig. 6. Solid state structure of $t-\mathrm{Bu}_{3} \mathrm{Al}-\mathrm{Sb}(i-\mathrm{Pr})_{3}$

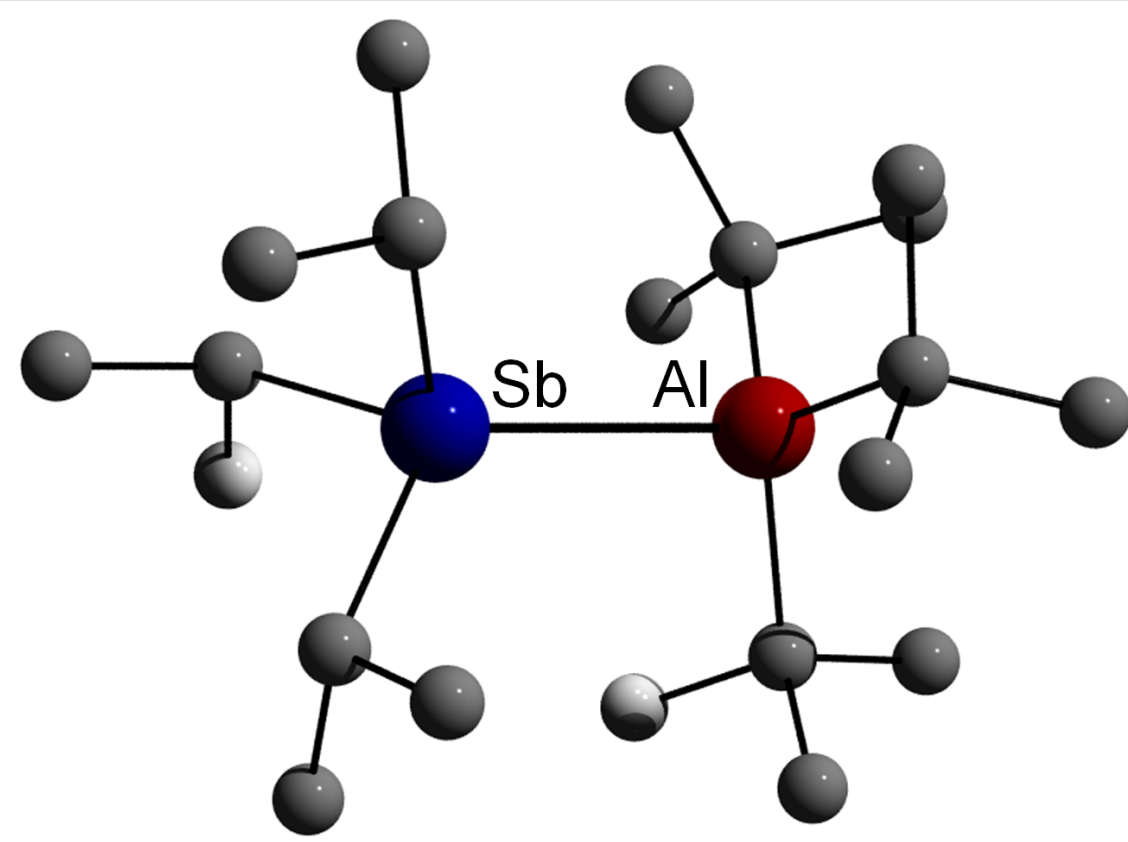

Fig. 7. Solid state structure of $t-\mathrm{Bu} \mathrm{u}_{3} \mathrm{Al}-\mathrm{Bi}(i-\mathrm{Pr})_{3}$ 


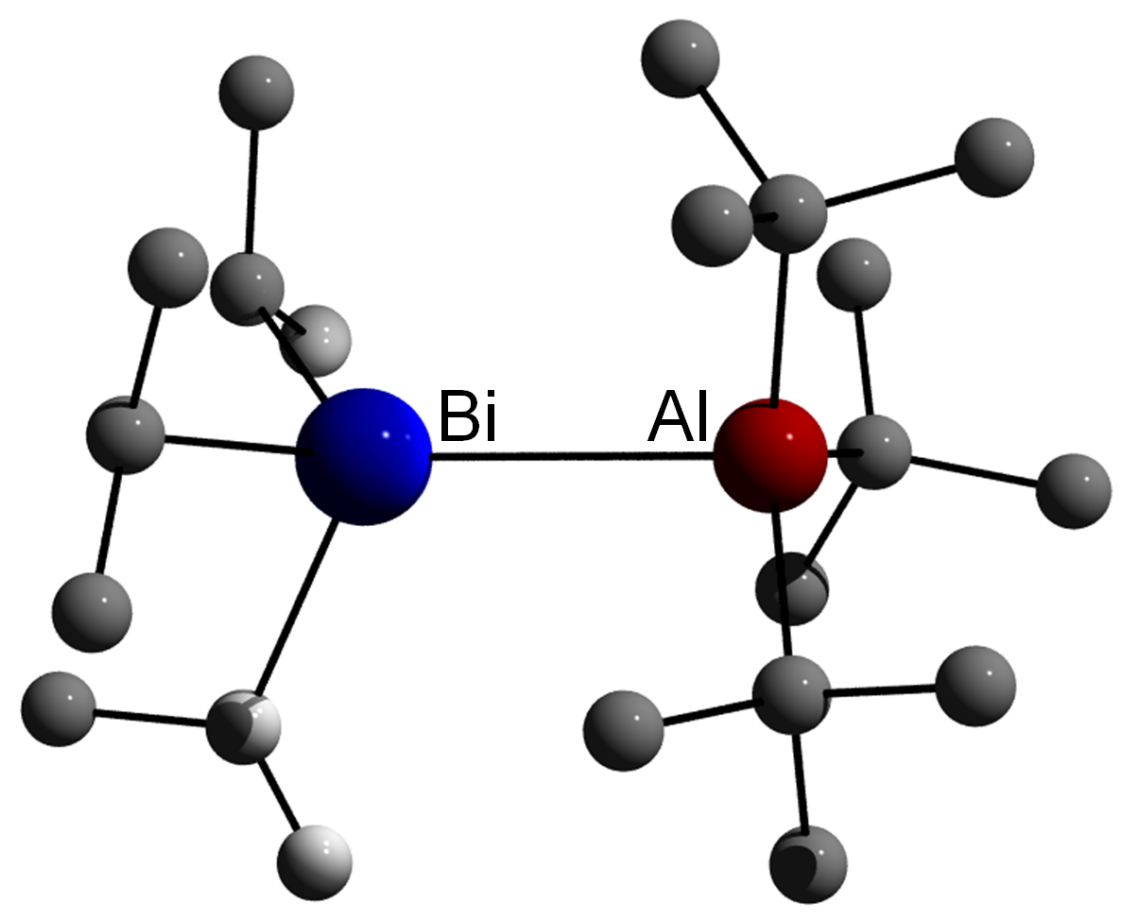

Tetraalkyldistibines and -dibismuthines typically bind in a bidentated fashion when reacted with $A l R_{3}$ Lewis acids, yielding adducts of the type $\left[\mathrm{R}_{3} \mathrm{Al}\right]_{2}\left[\mathrm{E}_{2} \mathrm{R}_{4}\right]$ $\left(\mathrm{E}=\mathrm{Sb}[53,55,57]\right.$, Bi [58], Fig. 9). Only the sterically crowded $i-\mathrm{Pr}_{4} \mathrm{Sb}_{2}$ was found to afford the monodentated complex [t-Bu $3 \mathrm{Al}]\left[\mathrm{Sb}_{2}(i-\mathrm{Pr})_{4}\right]$ (Fig. 8) [55]. These complexes represent the only distibine and dibismuthine complexes of main group metals. These results are strongly related to the already discussed weak Lewis basicity of $\mathrm{ER}_{3}$ derivatives, and reflect the expressed tendency of tetraalkyldistibines and -dibismuthines to undergo disproportionation reactions with subsequent formation of the respective metal $(\mathrm{Sb}, \mathrm{Bi})$ and the corresponding trialkylstibine and -bismuthine $\mathrm{R}_{3} \mathrm{E}$, respectively [63].

Fig. 8. Solid state structure of $\left[t-\mathrm{Bu}_{3} \mathrm{Al}\right]\left[\mathrm{Sb}_{2}(i-\mathrm{Pr})_{4}\right]$ 


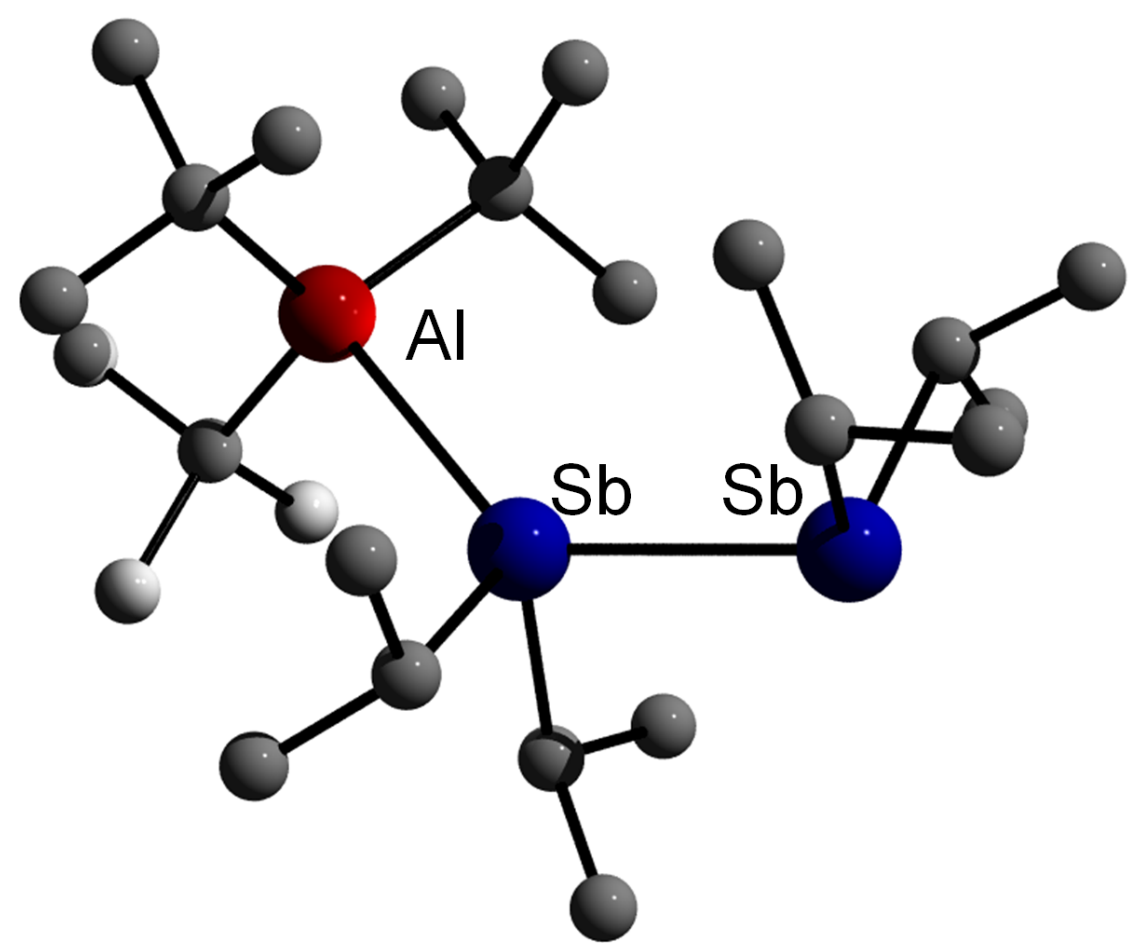

Fig. 9. Solid state structure of $\left[t-\mathrm{Bu}_{3} \mathrm{Al}_{2}\right]_{2}\left[\mathrm{Bi}_{2} \mathrm{Et}_{4}\right]$

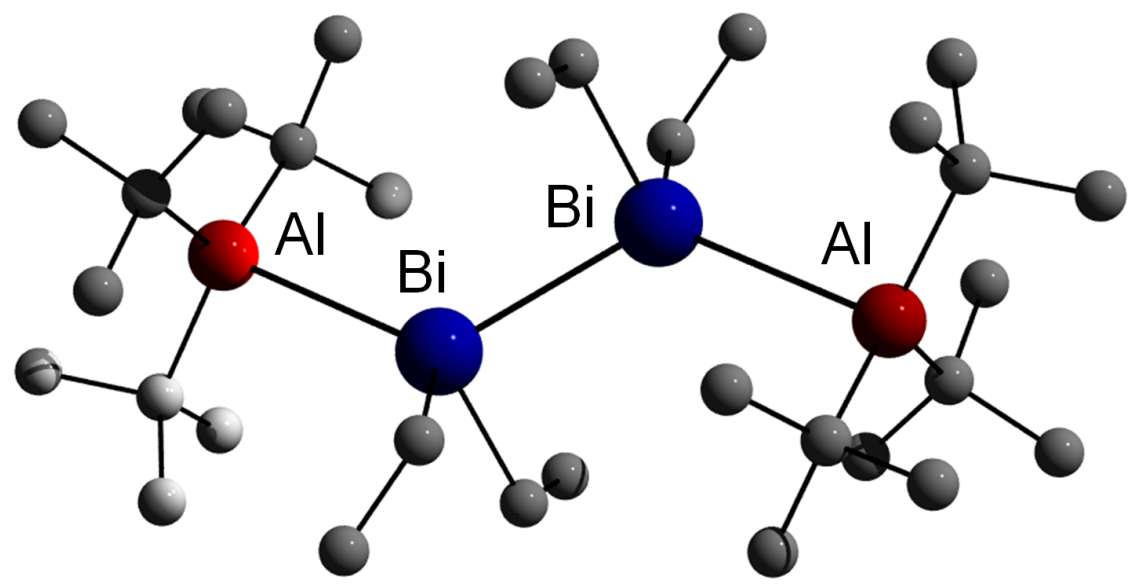

The bulky $t$ - $\mathrm{Bu}_{3} \mathrm{Al}$ groups in the bidentate complexes $\left[\mathrm{R}_{3} \mathrm{Al}_{2}\left[\mathrm{E}_{2} \mathrm{R}_{4}\right]\right.$ are, as expected, trans to one another for steric reasons. The Al-E bond lengths are comparable to those observed in simple trialkylstibine and -bismuthine adducts $\mathrm{R}_{3} \mathrm{Al}-$ 
$\mathrm{ER}_{3}$ and the central $\mathrm{Sb}-\mathrm{Sb}$ and $\mathrm{Bi}-\mathrm{Bi}$ bond distances are nearly identical to those in distibines and dibismuthines. These structural parameters agree with no E-E bond weakening upon adduct formation, which is consistent with rather weak Lewis acid-base interactions. The sum of C-Al-C bond angles in $t-\mathrm{Bu}_{3} \mathrm{Al}$, as estimated from gas phase (electron diffraction, 355.37 ${ }^{\circ}$ [64] and solid state structural data $\left(355.1,355.9^{\circ} ; 355.5^{\circ}\right)[65,66]$ is comparable to that in $\left[t-\mathrm{Bu}_{3} \mathrm{Al}_{2}\left[\mathrm{E}_{2} \mathrm{R}_{4}\right]\right.$ $\left(352.7^{\circ}\right.$ for the dibismuthine adduct $\left.\left[t-\mathrm{Bu}_{3} \mathrm{Al}\right]_{2}\left[\mathrm{Bi}_{2} \mathrm{Et}_{4}\right]\right)$, further substantiating weak Lewis acid-base bonding. Moreover, the sum of $\mathrm{C}-\mathrm{Sb}-\mathrm{C}$ and $\mathrm{C}-\mathrm{Sb}-\mathrm{Sb}$ bond angles is larger in the distibine adducts $\left[t-\mathrm{Bu}_{3} \mathrm{Al}_{2}\left[\mathrm{Sb}_{2} \mathrm{R}_{4}\right]\right.$ vs. those in $\mathrm{R}_{4} \mathrm{Sb}_{2}$, which points out a partial rehybridisation of the $\mathrm{Sb}$ centers as expected upon complexation [67]. In addition, the $\mathrm{C}-\mathrm{Bi}-\mathrm{X}(\mathrm{X}=\mathrm{C}, \mathrm{Bi})$ bond angular sum in dibismuthine adducts $\left[t-\mathrm{Bu}_{3} \mathrm{M}\right]_{2}\left[\mathrm{Bi}_{2} \mathrm{Et}_{4}\right]$ lies a bit above that observed in analogously substituted distibine adducts $\left[t-\mathrm{Bu}_{3} \mathrm{M}\right]_{2}\left[\mathrm{Sb}_{2} \mathrm{Et}_{4}\right]$. This may be rationalized by a slightly higher $p$-character for the $\mathrm{Bi}-\mathrm{C}$ and $\mathrm{Bi}-\mathrm{Bi}$ bonding electron pairs and an increased $s$-character for the dative Bi-M bonding electron pairs. Therefore, $\mathrm{Bi}_{2} \mathrm{Et}_{4}$ has to be considered as a weaker Lewis base than $\mathrm{Sb}_{2} \mathrm{Et}_{4}$.

\subsubsection{Heterocyclic Complexes $\left[\mathbf{R}_{2} \mathrm{AlER}_{2}\right]_{\mathrm{x}}$}

Numerous amido-, phosphido- and arsenide-alanes of the general type $\left[\mathrm{R}_{2} \mathrm{AlER}_{2}\right]_{\mathrm{x}}(\mathrm{x}=1,2,3)$ have been prepared following general and wellestablished synthetic routes via hydrogen elimination, alkane elimination, salt metathesis or dehalosilylation reactions (Fig. 10).

Fig. 10. Hydrogen elimination, alkane elimination, salt metathesis and dehalosilylation reactions

$$
\begin{aligned}
& \left.\mathrm{R}_{2} \mathrm{AlH}+\mathrm{HER}_{2} \longrightarrow \mathrm{R}_{2} \mathrm{AlER}_{2}^{\prime}\right]_{\mathrm{x}} \\
& \mathrm{E}=\mathrm{N}, \mathrm{P},(\mathrm{As}) ; \mathrm{R}, \mathrm{R}^{\prime}=\mathrm{H} \text {, alkyl, aryl } \\
& \mathrm{R}_{3} \mathrm{Al}+\mathrm{HER}_{2} \longrightarrow \underset{-\mathrm{RH}}{[}\left[\mathrm{R}_{2} \mathrm{AlER}_{2}\right]_{\mathrm{x}} \\
& \mathrm{E}=\mathrm{N}, \mathrm{P},(\mathrm{As}) ; \mathrm{R}, \mathrm{R}^{\prime}=\mathrm{H} \text {, alkyl, aryl } \\
& \begin{array}{ll}
\mathrm{R}_{2} \mathrm{AlCl}+\mathrm{M}^{\prime} \mathrm{ER}_{2} \longrightarrow \mathrm{M}_{2} \mathrm{Cl} \longrightarrow & {\left[\mathrm{R}_{2} \mathrm{AlER}_{2}\right]_{\mathrm{x}}} \\
& \mathrm{M} \mathbf{\prime}^{\prime}=\mathrm{Li},(\mathrm{Na}) ; ; \mathrm{E}=\mathrm{N}, \mathrm{P}, \mathrm{As} \\
\mathrm{R}, \mathrm{R}^{\prime}=\text { alkyl, aryl } &
\end{array} \\
& \mathrm{R}_{2} \mathrm{AICl}+\mathrm{R}_{2} \mathrm{ESiMe}_{3} \underset{-\mathrm{Me}_{3} \mathrm{SiCl}}{\longrightarrow}\left[\mathrm{R}_{2} \mathrm{AlER}_{2}\right]_{\mathrm{x}} \\
& \mathrm{E}=\mathrm{P}, \mathrm{As} ; \mathrm{R} \text {, alkyl, aryl; } \\
& \mathrm{R}^{\prime}=\text { alkyl, aryl, } \mathrm{SiMe}_{3}
\end{aligned}
$$

The synthetic routes highlighted in Fig. 10, successfully applied to the synthesis of the corresponding Al-P and Al-As heterocycles as well as Ga-Sb and $\mathrm{In}-\mathrm{Sb}$ heterocycles [68-76], were nevertheless shown to inappropriate for the synthesis of aluminum heterocycles of the heavier group 15 homologues ( $\mathrm{Sb}$ and $\mathrm{Bi}$ ). This most likely results from the less acidic properties of the $\mathrm{E}-\mathrm{H}$ group $(\mathrm{E}=\mathrm{Sb}, \mathrm{Bi})$ 
along with the well-documented propensity of stibides and bismuthides toward reduction and subsequent formation of elemental $\mathrm{Sb}$ and $\mathrm{Bi}$, respectively. Moreover, $\mathrm{R}_{2} \mathrm{AlCl}$ and $\mathrm{Sb}\left(\mathrm{SiMe}_{3}\right)_{3}(\mathrm{R}=\mathrm{Et}, t$ - $\mathrm{Bu})$ were observed not to undergo dehalosilylation as might be anticipated. Instead, the formation of the corresponding Lewis acid-base adducts was observed. In contrast, the reaction of $\mathrm{Me}_{2} \mathrm{AlCl}$ with $\mathrm{Sb}\left(\mathrm{SiMe}_{3}\right)_{3}$ yielded $\left[\mathrm{Me}(\mathrm{Cl}) \mathrm{AlSb}\left(\mathrm{SiMe}_{3}\right)_{2}\right]_{3}$, resulting from the elimination of $\mathrm{Me}_{4} \mathrm{Si}$ rather than $\mathrm{Me}_{3} \mathrm{SiCl}$. The different reactivity pattern observed for chloroalanes vs. chlorogallanes and -indanes primarily arise from two key characteristics:

1) the $\mathrm{Al}-\mathrm{Cl}$ bond is stronger than the $\mathrm{Ga}-\mathrm{Cl}$ and $\mathrm{In}-\mathrm{Cl}$ bonds $(\mathrm{Al}-\mathrm{Cl}$ bond $\left(\mathrm{D}^{\circ}{ }_{298}\left[\mathrm{kJmol}^{-1}\right]\right.$ : $\left.\mathrm{Al}-\mathrm{Cl} 511 \pm 1 ; \mathrm{Ga}-\mathrm{Cl} 481 \pm 13 ; \mathrm{In}-\mathrm{Cl} 439 \pm 8\right)$ )[77], disfavoring the elimination of $\mathrm{Me}_{3} \mathrm{SiCl}$, and

2) chloroalanes are stronger Lewis acids than their respectives chlorogallanes and -indanes, which favors the formation of Lewis acid-base adducts.

Therefore, novel reaction types had to be developed for their synthesis. On that matter, the dehydrosilylation reaction revealed to be an extremely powerful tool $[49,78-82]$. Thus, dehydrosilylation reactions $\left(\mathrm{Me}_{3} \mathrm{SiH}\right.$ elimination) can be performed at low temperatures $\left(0-50^{\circ} \mathrm{C}\right)$, allowing the isolation of the as-described heterocycles (frequently very temperature-labile) in very high yields (Fig. 11a and $11 \mathrm{~b}$ ). It is noteworthy that these syntheses can be performed in the absence of any organic solvent, facilitating the isolation of the resulting heterocycles.

Albeit not structurally characterized, $\left(\mathrm{Cp}^{*} \mathrm{Al}\right)_{3} \mathrm{Sb}_{2}$ was prepared by reaction of $[\mathrm{Cp} * \mathrm{Al}]_{4}$ with $[t-\mathrm{BuSb}]_{4}[83]$. Also, heterocyclic aluminum-, gallium- and indiumstibides $\left[\mathrm{R}_{2} \mathrm{MSbR}_{2}\right]_{\mathrm{x}}$ were produced via a novel distibine cleavage reaction [53, 55, 57, 84, 89] (Fig. 11c). On the other hand, a specific metathesis reaction using base-stabilized monomeric Al-pentelides of the type dmap- $\mathrm{AlMe}_{2} \mathrm{E}\left(\mathrm{SiMe}_{3}\right)_{2}(\mathrm{E}=$ $\mathrm{P}, \mathrm{As}, \mathrm{Sb}, \mathrm{Bi}$; dmap = 4-dimethylaminopyridine) allowed access to the corresponding heterocyclic gallium-, indium- and thallium-pentelides of the general type $\left[\mathrm{Me}_{2} \mathrm{MER}_{2}^{\prime}\right]_{\mathrm{x}}(\mathrm{M}=\mathrm{Ga}, \mathrm{In}, \mathrm{Tl} ; \mathrm{E}=\mathrm{P}, \mathrm{As}, \mathrm{Sb}, \mathrm{Bi})$ [85-88] (Fig. 11d).

Fig. 11. Dehydrosilylation reaction, distibine cleavage reaction and metathesis reactions 


$$
\begin{aligned}
& \begin{array}{lll}
\mathrm{R}_{2} \mathrm{AlH}+\mathrm{E}\left(\mathrm{SiMe}_{3}\right)_{3} \underset{-\mathrm{Me}_{3} \mathrm{SiH}}{\longrightarrow} & 1 / x\left[\mathrm{R}_{2} \mathrm{AlE}\left(\mathrm{SiMe}_{3}\right)_{2}\right]_{x} \\
\mathrm{E}=\mathrm{Sb}, \mathrm{Bi} ; \mathrm{R}=\text { alkyl }
\end{array} \\
& \begin{array}{lll}
\mathrm{R}_{2} \mathrm{AlH}+t-\mathrm{Bu}_{2} \mathrm{SbSiMe}_{3} \longrightarrow \begin{array}{l}
1 / x\left[\mathrm{R}_{2} \mathrm{AlSb}(t-\mathrm{Bu})_{2}\right]_{\mathrm{x}} \\
\mathrm{R}=\mathrm{Me}, \mathrm{Et}
\end{array} & \begin{array}{ll}
\mathrm{Me}_{3} \mathrm{SiH} \\
\mathrm{R}
\end{array}
\end{array} \\
& \left.\mathrm{R}_{3} \mathrm{M}+\mathrm{R}_{2} \mathrm{Sb}-\mathrm{SbR}_{2} \longrightarrow \mathrm{R}_{2} \mathrm{Sb} \mathrm{SbR}_{2} \longrightarrow \mathrm{Sb}_{2} \longrightarrow \mathrm{RSbR}_{2}\right]_{\mathrm{x}}+\mathrm{R}^{\prime} \mathrm{SbR}_{2} \\
& 1 / 3\left[\mathrm{Me}_{2} \mathrm{AlE}\left(\mathrm{SiMe}_{3}\right)_{2}\right]_{3}+\mathrm{Me}_{3} \mathrm{M}-\mathrm{dmap} \longrightarrow 1 / 3\left[\mathrm{Me}_{2} \mathrm{ME}\left(\mathrm{SiMe}_{3}\right)_{2}\right]_{3}
\end{aligned}
$$

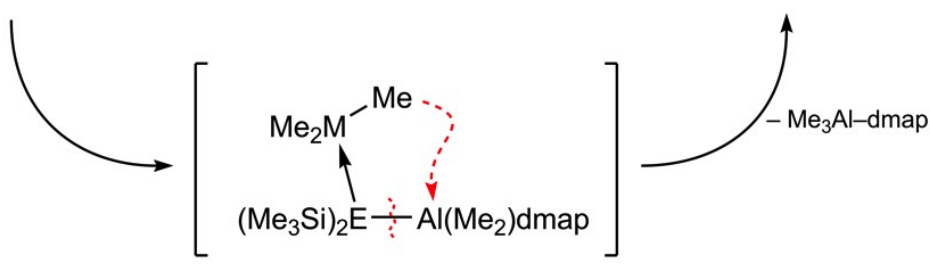

$$
\begin{aligned}
& M=G a, \operatorname{In}, T l ; E=P, A s, S b, B i
\end{aligned}
$$

Table 4. Selected bond lengths $(\AA)$ and angles $\left({ }^{\circ}\right)$ of heterocyclic stibidoalanes and bismuthidoalanes of the general type $\left[\mathrm{R}_{2} \mathrm{AlER}_{2}\right]_{x}$

\begin{tabular}{lllll}
\hline Heterocycle & M-E & Al-E-Al & E-Al-E & Ref \\
\hline$\left[\mathrm{Me}_{2} \mathrm{AlSb}\left(\mathrm{SiMe}_{3}\right)_{2}\right]_{3}$ & $2.703(1)-2.736(1)$ & $118.5(1)-128.2(1)$ & $103.5(1)-106.5(1)$ & 49 \\
{$\left[\mathrm{Et}_{2} \mathrm{AlSb}\left(\mathrm{SiMe}_{3}\right)_{2}\right]_{2}$} & $2.723(1), 2.729(1)$ & $91.7(1)$ & $88.3(1)$ & 78 \\
{$\left[i-\mathrm{Bu}{ }_{2} \mathrm{AlSb}\left(\mathrm{SiMe}_{3}\right)_{2}\right]_{2}$} & $2.743(1), 2.746(1)$ & $93.7(1)$ & $86.3(1)$ & 78 \\
{$\left[t-\mathrm{Bu}_{2} \mathrm{AlSb}\left(\mathrm{SiMe}_{3}\right)_{2}\right]_{2}$} & $2.748(1), 2.748(1)$ & $96.1(1)$ & $83.9(1)$ & 82 \\
$\left(\mathrm{Me}_{2} \mathrm{Al}\right)_{3}\left(\mathrm{Sbt}_{-}\right.$ & $2.719(2)-2.780(2)$ & $115.4(1)-128.4(1)$ & $103.1(1)-106.9(1)$ & 79 \\
$\left.\mathrm{Bu}_{2}\right)_{2} \mathrm{Sb}(\mathrm{SiMe})_{2}$ & & & & \\
{$\left[\mathrm{Me}_{2} \mathrm{AlSb}(t-\mathrm{Bu})_{2}\right]_{3}$} & $2.719(1)-2.784(1)$ & $115.3(1)-128.9(1)$ & $102.8(1)-108.2(1)$ & 79 \\
{$\left[t-\mathrm{Bu}{ }_{2} \mathrm{AlSbEt}\right.$} & \\
{$\left[\mathrm{Me}_{2} \mathrm{AlBi}\left(\mathrm{SiMe}_{3}\right)_{2}\right]_{3}$} & $2.781(1), 2.786(1)$ & $94.1(1), 94.3(1)$ & $85.8(1)$ & 89 \\
{$\left[t-\mathrm{Bu}{ }_{2} \mathrm{AlBi}\left(\mathrm{SiMe}_{3}\right)_{2}\right]_{2}$} & $2.755(3)-2.793(3)$ & $121.7(1)-130.5(1)$ & $101.0(1)-104.1(1)$ & 80 \\
\hline
\end{tabular}

Stibidoalanes $\left[\mathrm{R}_{2} \mathrm{AlSbR}_{2}\right]_{\mathrm{x}}\left(\mathrm{R}=\right.$ alkyl, $\mathrm{R}^{\prime}=$ alkyl, $\left.\mathrm{SiMe}_{3}\right)$ and bismuthidoalanes $\left[\mathrm{R}_{2} \mathrm{AlBi}\left(\mathrm{SiMe}_{3}\right)_{2}\right]_{x}(\mathrm{R}=$ alkyl $)$ adopt either dimeric or trimeric structures in the solid state, depending on the steric bulk of the organic substituents. Analogous findings were previously observed for the lighter group 15 homologues. Sterically demanding substituents favor the formation of four-membered heterocycles, whereas smaller organic substituents yield six-membered heterocycles. Obviously, the nature of the formed heterocycle depends on ring strain and entrpty effects. Thus, the formation of six-membered rings relate to the larger Al-E-Al and E-Al-E 
bond angles that results while entropy effects favor the formation of fourmembered rings. Large substituents tend to increase the $\mathrm{C}-\mathrm{Al}-\mathrm{C}$ and $\mathrm{C} / \mathrm{Si}-\mathrm{E}-\mathrm{C} / \mathrm{Si}$ bond angles; hence the E-Al-E and Al-E-Al angles should be rather small. As a consequence, four-membered rings are more stable than their six-membered ring analogues [90]. In addition, the central group 13 and group 15 elements of analogously substituted heterocycles also clearly influence the ring size. The influence of the group 15 element can be seen when comparing Me-substituted heterocycles $\left[\mathrm{Me}_{2} \mathrm{AlE}\left(\mathrm{SiMe}_{3}\right)_{2}\right]_{\mathrm{x}}$. The phosphido- and arsenidoalanes form four-membered heterocycles, whereas the stibido- and bismuthidoalanes adopt six-membered ring structures. The influence of the group 13 elements is observable in Et-substituted heterocycles $\left[\mathrm{Et}_{2} \mathrm{MSb}\left(\mathrm{SiMe}_{3}\right)_{2}\right]_{\mathrm{x}}$. Thus, compounds $\left[\mathrm{Et}_{2} \mathrm{AlSb}\left(\mathrm{SiMe}_{3}\right)_{2}\right]_{2}$ and $\left[\mathrm{Et}_{2} \mathrm{GaSb}\left(\mathrm{SiMe}_{3}\right)_{2}\right]_{2}$ form four-membered rings, whereas $\left[\mathrm{Et}_{2} \mathrm{InSb}\left(\mathrm{SiMe}_{3}\right)_{2}\right]_{3}$ adopts a six-membered ring structure.

Fig. 12. Solid state structure of $\left[t-\mathrm{Bu}_{2} \mathrm{AlBi}\left(\mathrm{SiMe}_{3}\right)_{2}\right]_{2}$

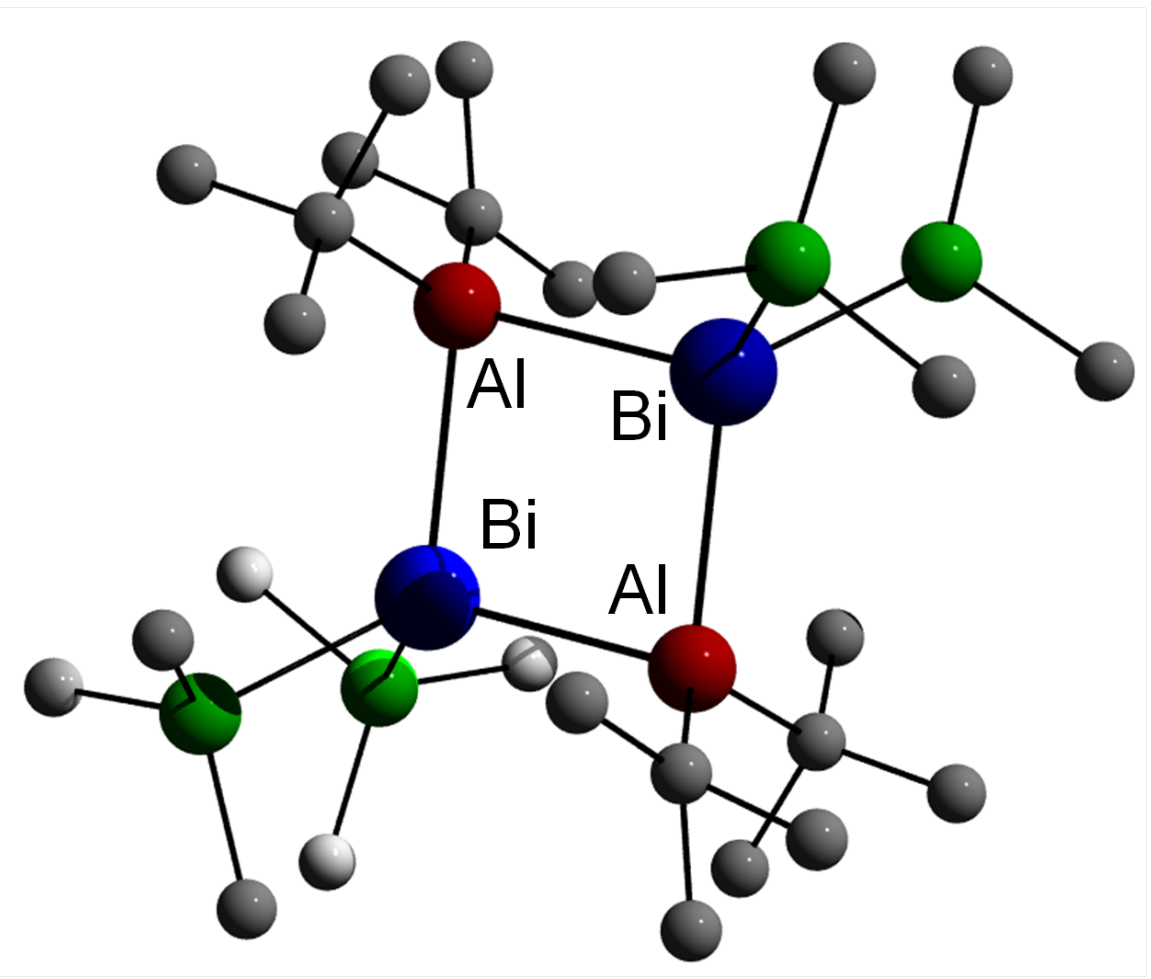

Fig. 13. Solid state structure of $\left[\mathrm{Me}_{2} \mathrm{AlBi}\left(\mathrm{SiMe}_{3}\right)_{2}\right]_{3}$ 


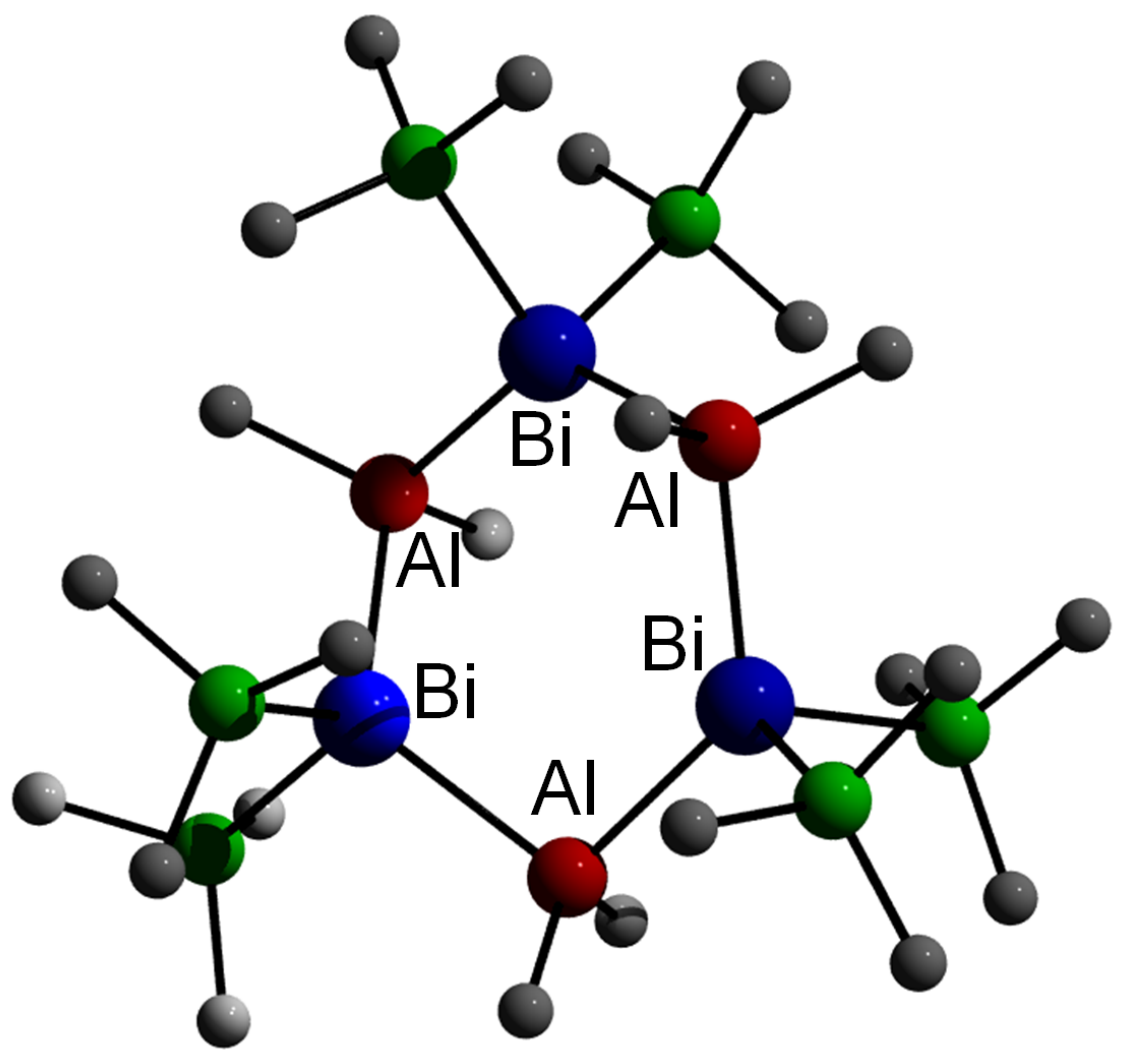

Table 5. Average bond lengths $(\AA)$ and angles $\left(^{\circ}\right)$ of analogously-substituted M-E heterocycles of the general type $\left[\mathrm{R}_{2} \mathrm{ME}\left(\mathrm{SiMe}_{3}\right)_{2}\right]_{\mathrm{x}}$

\begin{tabular}{|c|c|c|c|c|c|c|c|c|}
\hline M & $\mathrm{E}$ & $\mathrm{x}$ & M-E & E-M-E & M-E-M & $\mathrm{C}-\mathrm{M}-\mathrm{C}$ & Si-E-Si & Ref \\
\hline \multicolumn{9}{|c|}{$\left[\mathrm{Me}_{2} \mathrm{ME}\left(\mathrm{SiMe}_{3}\right)_{2}\right]_{\mathrm{x}}$} \\
\hline \multirow[t]{4}{*}{$\mathrm{Al}$} & $\mathrm{P}$ & 2 & 2.457 & 89.4 & 90.6 & 113.4 & 108.3 & 88 \\
\hline & As & 2 & 2.536 & 88.3 & 91.7 & 115.0 & 108.1 & 88 \\
\hline & $\mathrm{Sb}$ & 3 & 2.718 & 104.9 & 124.0 & 117.9 & 101.7 & 88 \\
\hline & $\mathrm{Bi}$ & 3 & 2.774 & 102.3 & 126.8 & 119.2 & 100.5 & 88 \\
\hline \multirow[t]{4}{*}{$\mathrm{Ga}$} & $\mathrm{P}$ & 2 & 2.450 & 88.2 & 91.8 & 114.4 & 108.0 & 88 \\
\hline & As & 2 & 2.530 & 87.0 & 93.0 & 116.8 & 107.7 & 88 \\
\hline & $\mathrm{Sb}$ & 3 & 2.691 & 105.2 & 123.6 & 118.1 & 101.6 & 88 \\
\hline & $\mathrm{Bi}$ & 3 & 2.762 & 102.0 & 127.0 & 120.1 & 100.3 & 81 \\
\hline \multirow[t]{3}{*}{ In } & $\mathrm{P}$ & 2 & 2.630 & 86.7 & 93.3 & 116.9 & 109.8 & 88 \\
\hline & As & 2 & 2.701 & 85.5 & 94.5 & 118.8 & 109.4 & 88 \\
\hline & $\mathrm{Sb}$ & 3 & 2.853 & 104.1 & 124.3 & 120.5 & 103.0 & 88 \\
\hline
\end{tabular}




\begin{tabular}{lllllllll}
\hline & $\mathrm{Bi}$ & 3 & 2.915 & 101.1 & 127.1 & 123.0 & 101.3 & 86 \\
$\mathrm{Tl}$ & $\mathrm{P}$ & 2 & 2.692 & 84.5 & 95.5 & 122.3 & 109.0 & 86 \\
& $\mathrm{As}$ & 2 & 2.762 & 93.3 & 96.7 & 124.6 & 108.5 & 86 \\
& $\mathrm{Sb}$ & 3 & 2.906 & 101.7 & 126.3 & 127.2 & 102.3 & 87 \\
{$\left[\mathrm{Et}_{2} \mathrm{ME}\left(\mathrm{SiMe}_{3}\right)_{2}\right]_{\mathrm{x}}$} & & & & & & & & \\
$\mathrm{Al}$ & $\mathrm{P}$ & 2 & 2.457 & 90.2 & 89.8 & 114.6 & 108.0 & 88 \\
& $\mathrm{As}$ & 2 & 2.565 & 89.6 & 90.4 & 115.1 & 109.3 & 88 \\
& $\mathrm{Sb}$ & 2 & 2.726 & 91.7 & 88.3 & 114.5 & 107.3 & 88 \\
$\mathrm{Ga}$ & $\mathrm{P}$ & 2 & 2.458 & 91.4 & 88.6 & 113.9 & 107.8 & 88 \\
& $\mathrm{As}$ & 2 & 2.544 & 92.2 & 87.8 & 114.2 & 107.5 & 88 \\
& $\mathrm{Sb}$ & 2 & 2.723 & 92.7 & 87.3 & 114.2 & 106.9 & 88 \\
$\mathrm{In}$ & $\mathrm{P}$ & 2 & 2.646 & 92.5 & 87.5 & 114.2 & 109.1 & 88 \\
& $\mathrm{As}$ & 2 & 2.712 & 93.6 & 86.4 & 114.6 & 108.5 & 88 \\
& $\mathrm{Sb}$ & 3 & 2.873 & 125.1 & 104.4 & 116.8 & 101.2 & 88 \\
\hline
\end{tabular}

The six-membered heterocycles typically form non-planar rings in the solid state with distorted twist-boat conformations, in which the $\mathrm{Al}$ and $\mathrm{Sb} / \mathrm{Bi}$ atoms are arranged in distorted tetrahedral environments. The Al-E bond lengths $(\mathrm{E}=\mathrm{Sb}$ $2.70-2.78 \AA$, Bi $2.75-2.84 \AA$ ) are significantly shorter than those observed in the Lewis acid-base adducts $\mathrm{R}_{3} \mathrm{Al}-\mathrm{ER}_{3}$ and $\left[t-\mathrm{Bu}_{3} \mathrm{Al}\right]_{\times}\left[\mathrm{E}_{2} \mathrm{R}_{4}\right]$, respectively, but agree with the calculated single bond covalent radii $\left(\sum r_{\text {cov }}(\mathrm{AlSb}): 2.66 \AA\right.$; $\Sigma r_{\text {cov }}(\mathrm{AlBi}): 2.77 \AA$ ) [62]. As may be expected, the exocyclic C-Al-C bond angles strongly depend upon the steric hindrance of the $t$-Bu groups. Sterically demanding substituents thus lead to an opening of the C-Al-C bond angle, in turn decreasing the endocyclic E-Al-E bond angles and increasing the Al-E-Al bond angles.

\subsubsection{Monomeric Complexes dmap- $\mathrm{Al}\left(\mathrm{R}_{2}\right) \mathrm{ER}_{2}{ }_{2}$ and intermetallic complexes dmap-Al( $\left.\mathbf{R}_{2}\right) \mathbf{E R}^{\prime}{ }_{2}-\mathbf{M}^{\prime} \mathbf{R}^{\prime \prime}{ }_{\mathrm{n}}$}

While several heterocyclic stibidoalanes or bismuthidoalanes have been prepared and structurally characterized (vide supra), monomeric derivatives $\mathrm{R}_{2} \mathrm{Al}$ $\mathrm{ER}_{2}$ are unknown. In contrast, base-stabilized complexes of the general type dmap- $\mathrm{Al}\left(\mathrm{R}_{2}\right) \mathrm{ER}_{2}{ }_{2}$ were prepared by reaction of the heterocycles $\left[\mathrm{R}_{2} \mathrm{AlE}\left(\mathrm{SiMe}_{3}\right)_{2}\right]_{\mathrm{x}}$ with strong Lewis bases such as 4-dimethylaminopyridine (dmap) (Fig. 14c) [9194]. In addition, base-stabilized phosphanyl- and arsanylalanes $\mathrm{Me}_{3} \mathrm{~N}-\mathrm{Al}\left(\mathrm{H}_{2}\right) \mathrm{ER}_{2}$ $(\mathrm{E}=\mathrm{P}, \mathrm{As})$ are available by a metathetical reaction between the base-stabilized alane $\mathrm{Me}_{3} \mathrm{~N}-\mathrm{Al}\left(\mathrm{H}_{2}\right) \mathrm{Cl}$ and $\mathrm{LiER}_{2}\left(\mathrm{E}=\mathrm{P}, \mathrm{As} ; \mathrm{R}=\mathrm{Mes}=2,4,6-\mathrm{Me}_{3} \mathrm{C}_{6} \mathrm{H}_{2}\right)(\mathrm{Fig}$. 14b) [95] and by a dehalosilylation reaction between $\mathrm{H}_{3} \mathrm{Al} \cdot \mathrm{NMe}_{3}$ and $\mathrm{E}\left(\mathrm{SiMe}_{3}\right)_{3}$ $(\mathrm{E}=\mathrm{P}$, As) (Fig. 14a) [96].

Fig. 14. Synthesis of base-stabilized monomers 


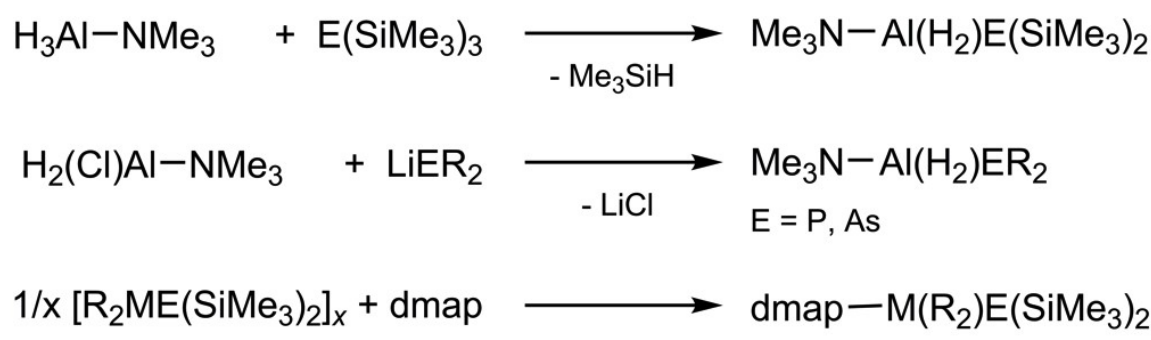

$\mathrm{M}=\mathrm{Al}, \mathrm{Ga} ; \mathrm{E}=\mathrm{P}, \mathrm{As}, \mathrm{Sb}, \mathrm{Bi}$

Base-stabilized monomeric compounds feature the shortest Al-E bond lengths observed to date, a likely consequence of the lower coordination number of the group 15 metal center. Following an analogous trend earlier mentioned, the degree of pyramidalization of substituted alanes dmap- $\mathrm{Al}\left(\mathrm{R}_{2}\right) \mathrm{E}\left(\mathrm{SiME}_{3}\right)_{2}(\mathrm{E}=\mathrm{P}$ to $\mathrm{Bi} ; \mathrm{R}$ $=\mathrm{Me}, \mathrm{Et})$ steadily decreases when going to heavier group 15 elements. Analogous structural trends were observed for group 15 triorganyls such as $\mathrm{EH}_{3}, \mathrm{EPh}_{3}$ and $\mathrm{EMe}_{3}$. The decreasing bond angles mainly result from an increased $s$-character of the electron lone pair on the group 15 element.

Table 6. Selected bond lengths $(\AA)$ and angles $\left({ }^{\circ}\right)$ of dmap-stabilized monomers dmap$\mathrm{Al}\left(\mathrm{Me}_{2}\right) \mathrm{E}\left(\mathrm{SiMe}_{3}\right)_{2}$

\begin{tabular}{|c|c|c|c|c|c|}
\hline Monomer & M-E & $\mathrm{M}-\mathrm{N}$ & M-R (av.) & $\Sigma \mathrm{X}-\mathrm{E}-\mathrm{X}$ & Ref \\
\hline dmap- $\mathrm{Al}\left(\mathrm{Me}_{2}\right) \mathrm{P}\left(\mathrm{SiMe}_{3}\right)_{2}$ & $2.379(1)$ & $1.984(2)$ & 1.975 & 309.1 & 88 \\
\hline dmap-Al( $\left(\mathrm{Me}_{2}\right) \mathrm{As}\left(\mathrm{SiMe}_{3}\right)_{2}$ & $2.472(2)$ & $1.975(4)$ & 1.968 & 304.1 & 88 \\
\hline dmap- $\mathrm{Al}\left(\mathrm{Et}_{2}\right) \mathrm{As}\left(\mathrm{SiMe}_{3}\right)_{2}$ & $2.473(1)$ & $1.988(3)$ & 1.977 & 306.6 & 88 \\
\hline dmap- $\mathrm{Al}\left(\mathrm{Me}_{2}\right) \mathrm{Sb}\left(\mathrm{SiMe}_{3}\right)_{2}$ & $2.691(1)$ & $1.978(2)$ & 1.970 & 302.4 & 88 \\
\hline dmap- $\mathrm{Al}\left(\mathrm{Et}_{2}\right) \mathrm{Sb}\left(\mathrm{SiMe}_{3}\right)_{2}$ & $2.680(1)$ & $1.980(2)$ & 1.980 & 298.9 & 88 \\
\hline $\mathrm{dmap}-\mathrm{Al}\left(\mathrm{Et}_{2}\right) \mathrm{Sb}(t-\mathrm{Bu})_{2}$ & $2.708(4)$ & $1.989(2)$ & 1.989 & 306.8 & 94 \\
\hline dmap- $\mathrm{Al}\left(\mathrm{Me}_{2}\right) \mathrm{Bi}\left(\mathrm{SiMe}_{3}\right)_{2}$ & $2.755(2)$ & $1.972(4)$ & 1.972 & 296.8 & 88 \\
\hline dmap- $\mathrm{Al}\left(\mathrm{Et}_{2}\right) \mathrm{Bi}\left(\mathrm{SiMe}_{3}\right)_{2}$ & $2.750(2)$ & $1.978(5)$ & 1.988 & 293.4 & 88 \\
\hline dmap- $\mathrm{Ga}\left(\mathrm{Me}_{2}\right) \mathrm{P}\left(\mathrm{SiMe}_{3}\right)_{2}$ & $2.372(1)$ & $2.080(2)$ & 1.985 & 305.3 & 88 \\
\hline dmap- $\mathrm{Ga}\left(\mathrm{Me}_{2}\right) \mathrm{As}\left(\mathrm{SiMe}_{3}\right)_{2}$ & $2.455(1)$ & $2.082(2)$ & 1.982 & 300.2 & 88 \\
\hline dmap- $\mathrm{Ga}\left(\mathrm{Et}_{2}\right) \mathrm{Sb}\left(\mathrm{SiMe}_{3}\right)_{2}$ & $2.648(1)$ & $2.066(2)$ & 1.994 & 298.0 & 88 \\
\hline
\end{tabular}

The use of strong $\sigma$-donor ligands (Lewis bases) has recently been demonstrated to be extremely profitable for the stabilization of unprecedented main group element compounds. Based on the work of Robinson et al, who reported on the synthesis and structure of the carbene-stabilized disilicon complex $\mathrm{L}-\mathrm{Si}=\mathrm{Si}-\mathrm{L}(\mathrm{L}=$ $\left.\mathrm{C}\left[\mathrm{N}\left(2,6-i-\mathrm{Pr}_{2}-\mathrm{C}_{6} \mathrm{H}_{3}\right) \mathrm{CH}\right]_{2}\right)$ [97], several elusive compounds including the parent complexes $\mathrm{L}-\mathrm{HB}=\mathrm{BH}-\mathrm{L}, \mathrm{L}-\mathrm{P}-\mathrm{P}-\mathrm{L}$ and others [98-100], long considered not to be isolable, have been structurally characterized. Moreover, Scheer et al. demonstrated that the coordination of both a Lewis base and a transition metal complex stabilizes highly unstable compounds such as monomeric phosphanylalanes and - 
gallanes. Thus, compounds $\mathrm{Me}_{3} \mathrm{~N}-\mathrm{M}\left(\mathrm{H}_{2}\right) \mathrm{PH}_{2}-\mathrm{W}(\mathrm{CO})_{5}(\mathrm{M}=\mathrm{Al}, \mathrm{Ga})$ were produced by a $\mathrm{H}_{2}$ elimination reaction between $\mathrm{W}(\mathrm{CO})_{5} \mathrm{PH}_{3}$ and $\mathrm{Me}_{3} \mathrm{~N}-\mathrm{MH}_{3}$ [101] According to theoretical calculations, coordination of $\mathrm{NMe}_{3}(108 \mathrm{~kJ} / \mathrm{mol})$ and $\mathrm{W}(\mathrm{CO})_{5}(154 \mathrm{~kJ} / \mathrm{mol})$ to $\mathrm{H}_{2} \mathrm{AlPH}_{2}$ stabilizes the monomeric unit by $262 \mathrm{~kJ} / \mathrm{mol}$, while the dimerization of phosphanylalane $\mathrm{H}_{2} \mathrm{AlPH}_{2}$ would only provide an energy stabilization of $74 \mathrm{~kJ} / \mathrm{mol}$.

Fig. 15. Solid state structure of dmap- $\mathrm{Al}\left(\mathrm{Me}_{2}\right) \mathrm{Bi}\left(\mathrm{SiMe}_{3}\right)_{2}$

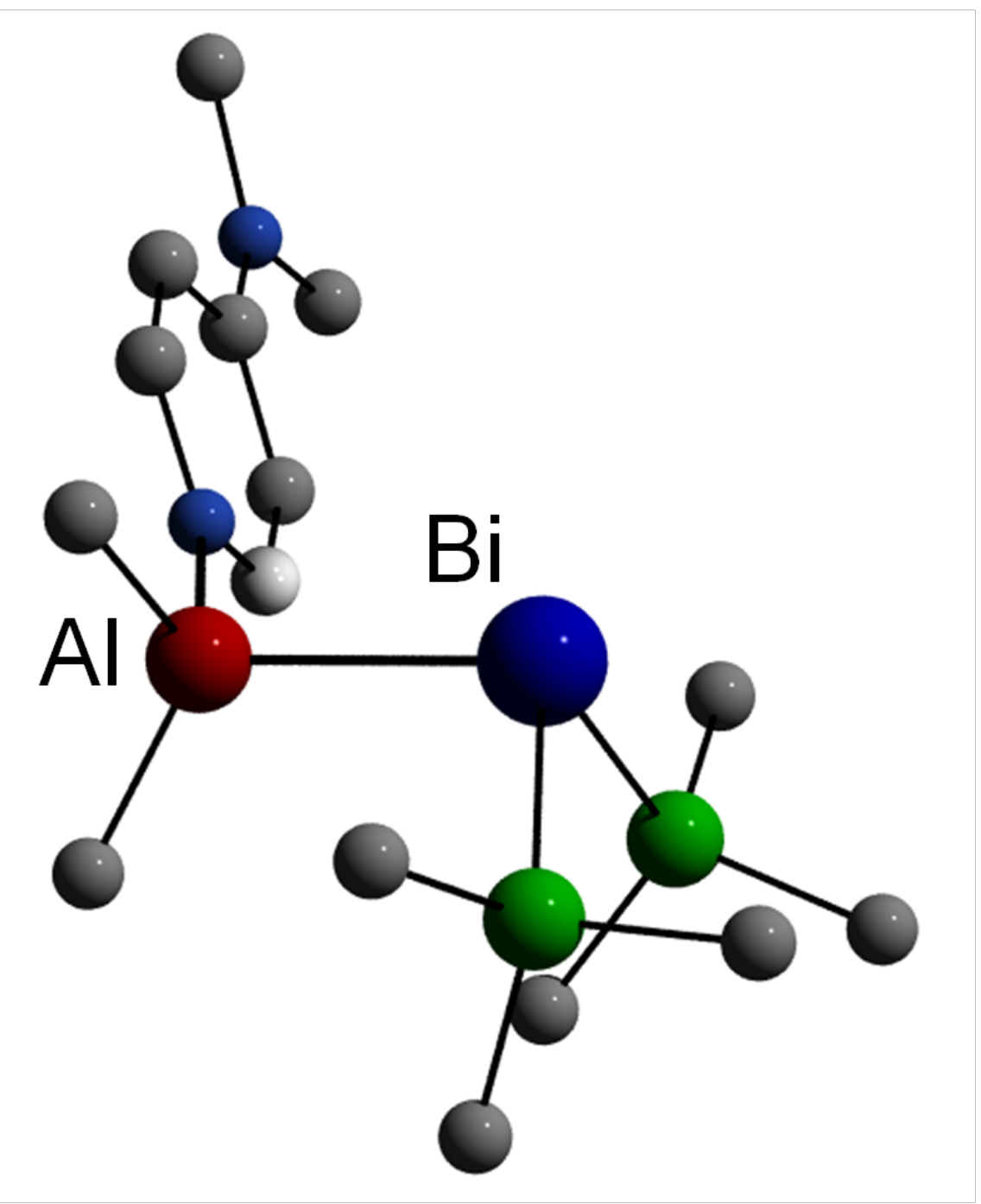

Fig. 16. Solid state structure of dmap- $\mathrm{Al}\left(\mathrm{Me}_{2}\right) \mathrm{Sb}\left(\mathrm{SiMe}_{3}\right)_{2}-\mathrm{Ga}(t-\mathrm{Bu})_{3}$ 


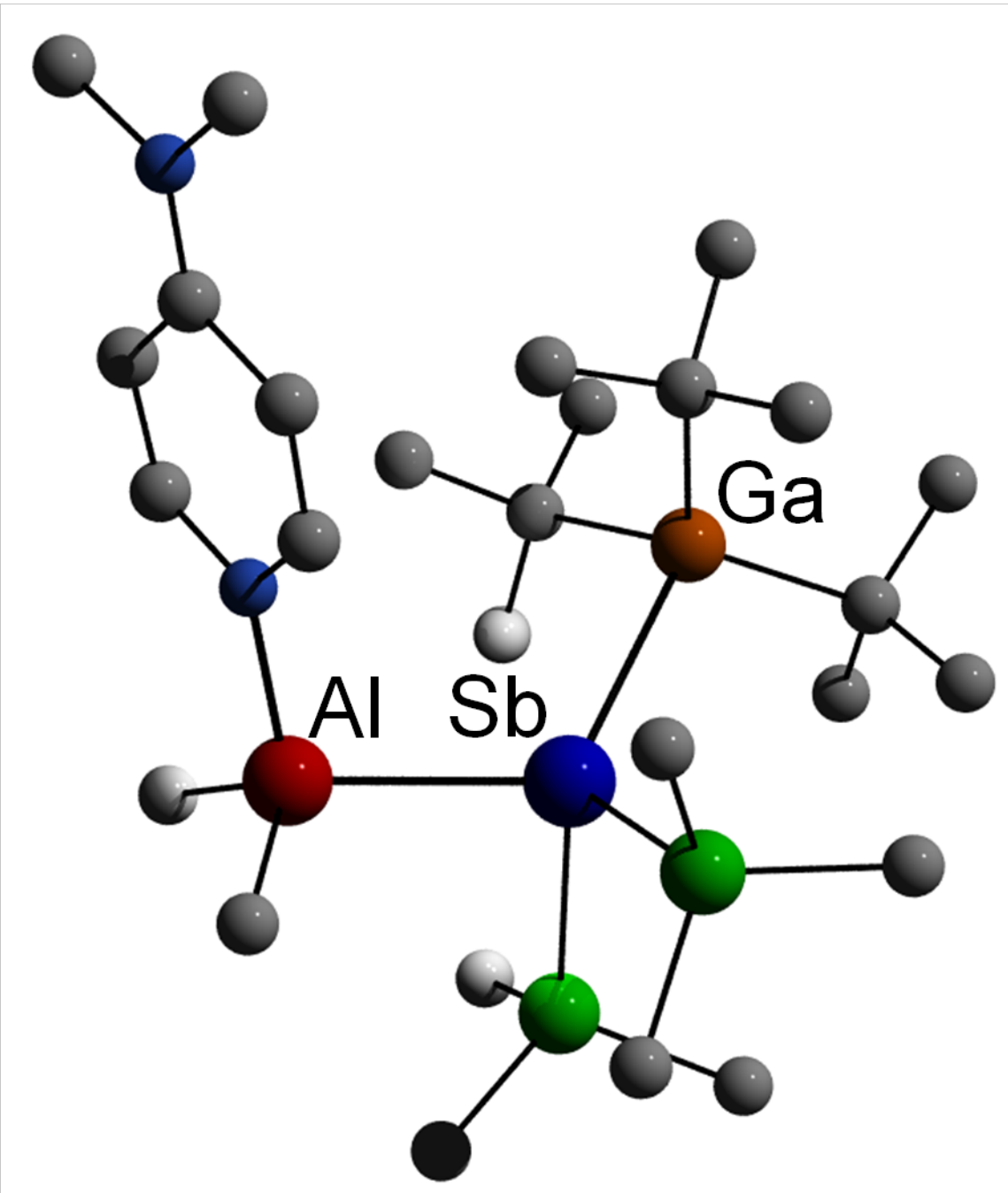

Comparable compounds of the type dmap-M( $\left(\mathrm{Me}_{2}\right) \mathrm{E}\left(\mathrm{SiMe}_{3}\right)_{2}-\mathrm{M}^{\prime}(\mathrm{CO})_{\mathrm{n}}(\mathrm{M}=$ $\left.\mathrm{Al}, \mathrm{Ga} ; \mathrm{E}=\mathrm{P}, \mathrm{As}, \mathrm{Sb} ; \mathrm{M}^{\prime}=\mathrm{Ni}, \mathrm{Fe}, \mathrm{Cr}\right)$ are generally accessible by reaction of the base-stabilized monomer dmap- $\mathrm{M}\left(\mathrm{Me}_{2}\right) \mathrm{E}\left(\mathrm{SiMe}_{3}\right)_{2}$ with transition metal carbonyls such as $\mathrm{Ni}(\mathrm{CO})_{4}, \mathrm{Fe}_{2}(\mathrm{CO})_{9}$ and $\left(\mathrm{Me}_{3} \mathrm{~N}\right) \mathrm{Cr}(\mathrm{CO})_{5}$, respectively $[102,103]$.

The carbonyl resonances in the ${ }^{13} \mathrm{C}$-NMR spectra agree with the dmap$\mathrm{M}\left(\mathrm{Me}_{2}\right) \mathrm{E}\left(\mathrm{SiMe}_{3}\right)_{2}$ moiety being only a weak $\pi$-acceptor; hence the phosphorustransition metal interaction is essentially a $\mathrm{P}-\mathrm{M}$ ' $\sigma$-dative bond. According to the synergistic $\sigma$-donor $/ \pi$-acceptor bonding concept, these findings point toward a slightly higher $\sigma$-donor/ $\pi$-acceptor ratio when going down to heavier group 15 elements, as reported by Bodner et al. for over 100 transition metal complexes of the general type $\mathrm{R}_{3} \mathrm{E}-\mathrm{M}^{\prime} \mathrm{L}_{n}(\mathrm{E}=\mathrm{P}, \mathrm{As}, \mathrm{Sb})$ [104]. The observed trends were confirmed 
by single crystal $\mathrm{X}$-ray diffraction studies, showing an increase of the $\mathrm{Ni}-\mathrm{C}$ bond order and a decrease of the $\mathrm{C}-\mathrm{O}$ bond order in $\mathrm{Ni}(\mathrm{CO})_{3}$-containing complexes $v s$. $\mathrm{Ni}(\mathrm{CO})_{4}$. As reported for the simple Lewis acid-base adducts, the coordination to either a main group metal or a transition metal typically increases the $\mathrm{Si}-\mathrm{E}-\mathrm{Si}$ and Al-E-Si bond angles, a result of the enhanced p-character of the electron lone pair. Analogous trends were observed with trialkylalanes and -gallanes analogues dmap- $\mathrm{Al}\left(\mathrm{R}_{2}\right) \mathrm{E}\left(\mathrm{SiMe}_{3}\right)_{2}-\mathrm{MR}_{3}(\mathrm{E}=\mathrm{P}, \mathrm{Sb} ; \mathrm{M}=\mathrm{Al}, \mathrm{Ga})$ [85].

Table 7. Selected bond lengths $(\AA)$ and angles $\left(^{\circ}\right)$ of main group metal and transition metal complexes of the type base- $-M\left(R_{2}\right) E_{2}{ }_{2}-M^{\prime}{ }^{\prime}{ }_{n}$

\begin{tabular}{|c|c|c|c|c|c|}
\hline Complex & M-E & E-M' & $\mathrm{M}-\mathrm{N}$ & $\Sigma X-E-Y$ & Ref \\
\hline dmap- $\mathrm{Al}\left(\mathrm{Me}_{2}\right) \mathrm{P}\left(\mathrm{SiMe}_{3}\right)_{2}-\mathrm{GaMe}_{3}$ & $2.428(1)$ & $2.528(1)$ & $1.963(2)$ & 313.5 & 85 \\
\hline map- $\mathrm{Al}\left(\mathrm{Me}_{2}\right) \mathrm{Sb}\left(\mathrm{SiMe}_{3}\right)_{2}-\mathrm{Al}(\mathrm{t}-\mathrm{Bu})_{3}$ & 2 & 2.86 & $1.968(3)$ & 298.3 & 85 \\
\hline $\mathrm{Imap}-\mathrm{Al}\left(\mathrm{Me}_{2}\right) \mathrm{Sb}\left(\mathrm{SiMe}_{3}\right)_{2}-\mathrm{Ga}(\mathrm{t}-\mathrm{Bu})_{3}$ & $2.726(3)$ & $2.889(1)$ & $1.961(7)$ & 298.2 & 85 \\
\hline $\mathrm{le}_{3} \mathrm{~N}-$ & 2. & 2. & 2. & 3 & 105 \\
\hline $\mathrm{Me}_{3} \mathrm{~N}-\mathrm{Al}\left(\mathrm{H}_{2}\right) \mathrm{PH}_{2}-\mathrm{W}(\mathrm{CO})_{5}$ & $2.367(1)$ & $2.549(1)$ & $2.036(3)$ & - & 101 \\
\hline $\mathrm{Me}_{3} \mathrm{~N}-\mathrm{Ga}\left(\mathrm{H}_{2}\right) \mathrm{PH}_{2}-\mathrm{W}(\mathrm{CO})_{5}$ & $2.349(2)$ & $2.537(2)$ & $2.039(7)$ & - & 101 \\
\hline $\mathrm{P}\left(\mathrm{SiMe}_{3}\right)_{2}-\mathrm{Ni}(\mathrm{CO})_{3}$ & $2.400(2)$ & $2.319(2)$ & $1.961(5)$ & 326.0 & 102 \\
\hline dmap-Al(M & 1) & 1) & 1.96 & 318 & 102 \\
\hline $\operatorname{lmap}-\mathrm{Al}\left(\mathrm{Me}_{2}\right) \mathrm{P}(\mathrm{S}$ & 2.42 & 2.52 & 1.96 & 313 & 102 \\
\hline map- $\mathrm{Al}\left(\mathrm{Me}_{2}\right) \mathrm{As}\left(\mathrm{SiMe}_{3}\right)_{2}-\mathrm{Ni}(\mathrm{CO})_{3}$ & 2.479 & 1) & $1.966(2)$ & 3 & 103 \\
\hline Imap- $\mathrm{Al}\left(\mathrm{Me}_{2}\right) \mathrm{As}\left(\mathrm{SiMe}_{3}\right)_{2}-\mathrm{Cr}(\mathrm{CO})_{5}$ & $2.512(1)$ & 2.60 & $1.955(2)$ & 3 & 102 \\
\hline dmap- $\mathrm{Al}\left(\mathrm{Me}_{2}\right) \mathrm{Sb}\left(\mathrm{SiMe}_{3}\right)_{2}-\mathrm{Ni}(\mathrm{CO})_{3}$ & $2.680(2)$ & 2.556 & $1.965(4)$ & 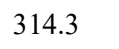 & 103 \\
\hline dmap- $\mathrm{Ga}\left(\mathrm{Me}_{2}\right) \mathrm{As}\left(\mathrm{SiMe}_{3}\right)_{2}-\mathrm{Ni}(\mathrm{CO})_{3}$ & 2.4 & 1) & $2.045(2)$ & 3 & 02 \\
\hline $\left.\mathrm{iMe}_{3}\right)_{2}-\mathrm{Ni}(\mathrm{CO})_{3}$ & $2.647(1)$ & $2.554(1)$ & $2.046(2)$ & 312.8 & 102 \\
\hline
\end{tabular}

\subsection{Organoaluminum Complexes with other p-Block Metals (Sn, $\mathrm{Pb}, \mathrm{Te})$}

In sharp contrast with intermolecular complexes with direct $\mathrm{Al} /$ group 15 bonds, analogous molecular organoaluminum complexes but with bonds to group 14 (Sn, $\mathrm{Pb})$ and group 16 metals $(\mathrm{Te})$ are rather rare. To date, compound $[t-$ $\mathrm{BuNSn}]_{4}\left[\mathrm{AlCl}_{3}\right]_{2}$, prepared by reaction of $[t-\mathrm{BuNSn}]_{4}$ with two equivalents of $\left[\mathrm{AlCl}_{3}\right]$, constitutes the only structurally characterized complex containing a dative $\mathrm{Sn}-\mathrm{Al}$ bond [106]. In addition, the synthesis of $\mathrm{Cp}_{2} \mathrm{Sn}_{-} \mathrm{AlX}_{3}(\mathrm{X}=\mathrm{Cl}, \mathrm{Br})$ was reported [107]. In these complexes, the $\mathrm{Sn}(\mathrm{II})$ atom coordinates through its electron lone pair to the Lewis acidic aluminum trihalides.

There are several examples of structurally characterized organoaluminum complexes containing at least one direct Al-Te. Such entities are typically prepared by 
an insertion reaction of elemental Te and an alane derivative containing either an Al-C [108, 109] or an Al-H bond [110-115] (Fig. 17a). Also, the reaction of the subvalent organoaluminum complex $\left[\mathrm{Cp}^{*} \mathrm{Al}\right]_{4}$ with elemental $\mathrm{Te}$ was found to proceed via the insertion of Te into the Al-Al bond and formation of the corresponding heterocubane $\left[\mathrm{Cp}^{*} \mathrm{AlTe}\right]_{4}[116]$ (Fig. 17b). In an analogous manner, the reaction of $\left[\left(\mathrm{Me}_{3} \mathrm{Si}\right)_{2} \mathrm{CH}\right]_{2} \mathrm{Al}-\mathrm{Al}\left[\mathrm{CH}\left(\mathrm{SiMe}_{3}\right)_{2}\right]_{2}$ with elemental tellurium afforded monomeric $\left[\left(\mathrm{Me}_{3} \mathrm{Si}\right)_{2} \mathrm{CH}\right]_{2} \mathrm{Al}-\mathrm{Te}-\mathrm{Al}\left[\mathrm{CH}\left(\mathrm{SiMe}_{3}\right)_{2}\right]_{2}$ ( Fig. 17c) [117].

Fig. 17. General reaction pathways for the synthesis of organoaluminum telluride complexes

$$
\begin{aligned}
& \mathrm{R}_{2} \mathrm{Al}-\mathrm{R}+\mathrm{Te} \longrightarrow \mathrm{R}_{2} \mathrm{Al}-\mathrm{Te}-\mathrm{R} \\
& \mathrm{R}=\mathrm{H} \text {, alkyl } \\
& {\left[\mathrm{Cp}^{*} \mathrm{Al}\right]_{4}+4 \mathrm{Te} \longrightarrow\left[\mathrm{Cp}^{*} \mathrm{AlTe}\right]_{4}} \\
& \mathrm{R}_{2} \mathrm{Al}^{-\mathrm{AlR}_{2}}+\mathrm{Te} \longrightarrow \mathrm{R}_{2} \mathrm{Al}-\mathrm{Te}-\mathrm{AlR}_{2} \\
& \mathrm{R}=\mathrm{CH}\left(\mathrm{SiMe}_{3}\right)_{2}
\end{aligned}
$$

The solid state molecular structures of these complexes essentially depend on the sterics of the R organic groups. Typically, heterocubane-like structures [RAl$\mathrm{Te}]_{4}\left(\mathrm{R}=\mathrm{Cp}^{*}\right.$ [116], $\mathrm{Me}_{2}(\mathrm{Et}) \mathrm{C}$ [109], $t$-Bu [108], $\mathrm{C}\left(\mathrm{SiMe}_{3}\right)_{3}$ [112]) were observed. Geometries and thermodynamics of these group 13/16 hetero-cubanes $[\mathrm{RME}]_{4}(\mathrm{M}=\mathrm{Al}, \mathrm{Ga}, \mathrm{In} ; \mathrm{E}=\mathrm{O}, \mathrm{S}, \mathrm{Se}, \mathrm{Te})$ have also been estimated via DFT studies, suggesting their thermodynamic stability toward fragmentation reactions [118]. Interestingly, treatment of neat $t-\mathrm{Bu}_{3} \mathrm{Al}$ with two equivalents of elemental tellurium yielded the dimeric complex $\left[t-\mathrm{Bu}_{2} \mathrm{AlTe}(t-\mathrm{Bu})\right]_{2}$, formally resulting from the insertion of Te into an Al-C bond. Prolonged heating of the latter (toluene, 100 ${ }^{\circ} \mathrm{C}, 48 \mathrm{~h}$ ) afforded the heterocubane $[t \text {-BuAlTe }]_{4}$. Alternatively, $[t-\mathrm{BuAlTe}]_{4}$ may be formed via a controlled pyrolysis of $[t-\operatorname{Bu} 2 \mathrm{AlTe}(t-\mathrm{Bu})]_{2}\left(300^{\circ} \mathrm{C}, 1 \mathrm{~atm}\right)[108]$.

Fig. 18. Solid state structure of $[\mathrm{Cp} * \mathrm{AlTe}]_{4}$ 


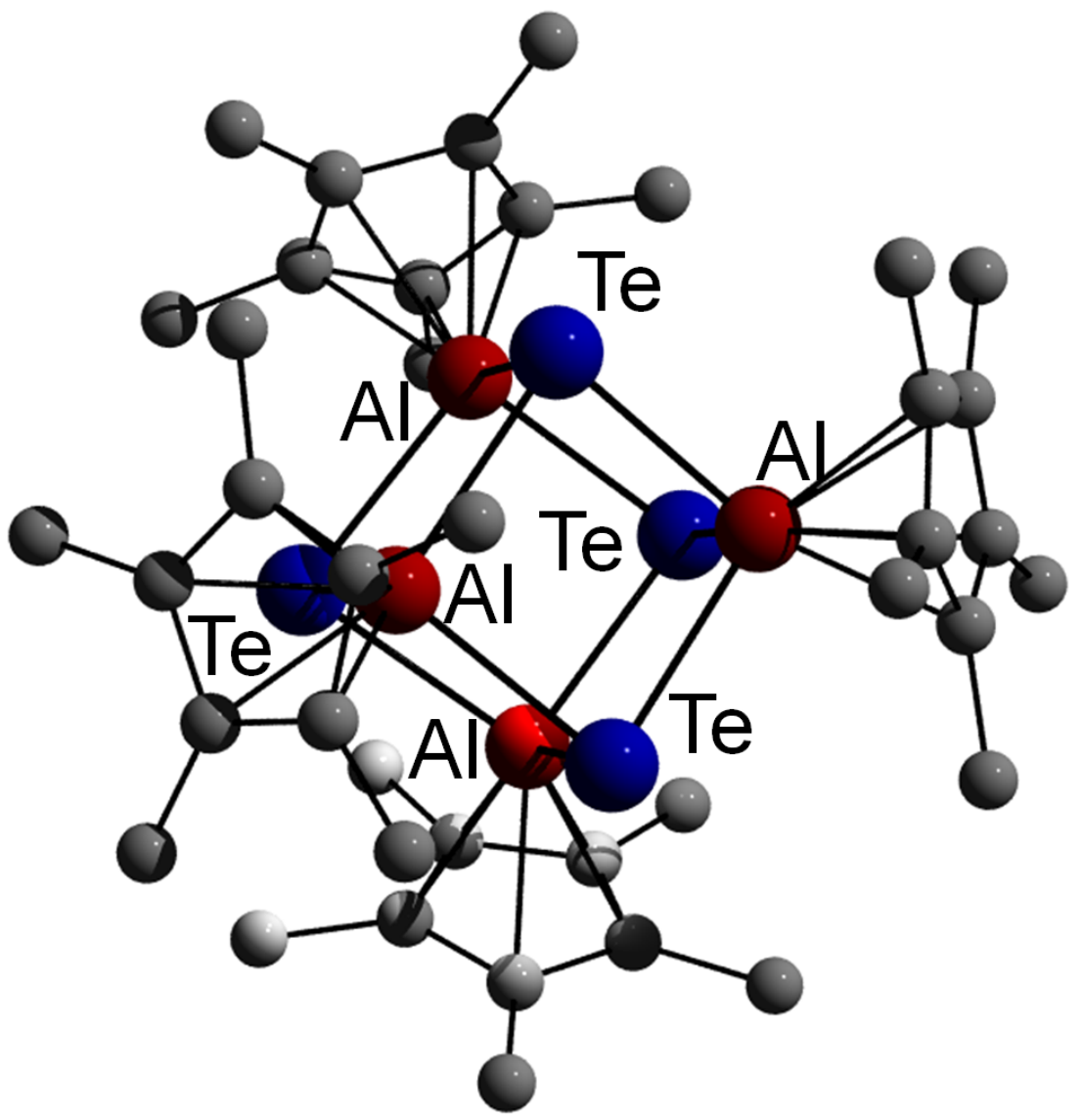

Fig. 19. Solid state structure of $\left[\mathrm{Me}_{3} \mathrm{NAl}(\mathrm{H})(\mu-\mathrm{Te})\right]_{2}$ 


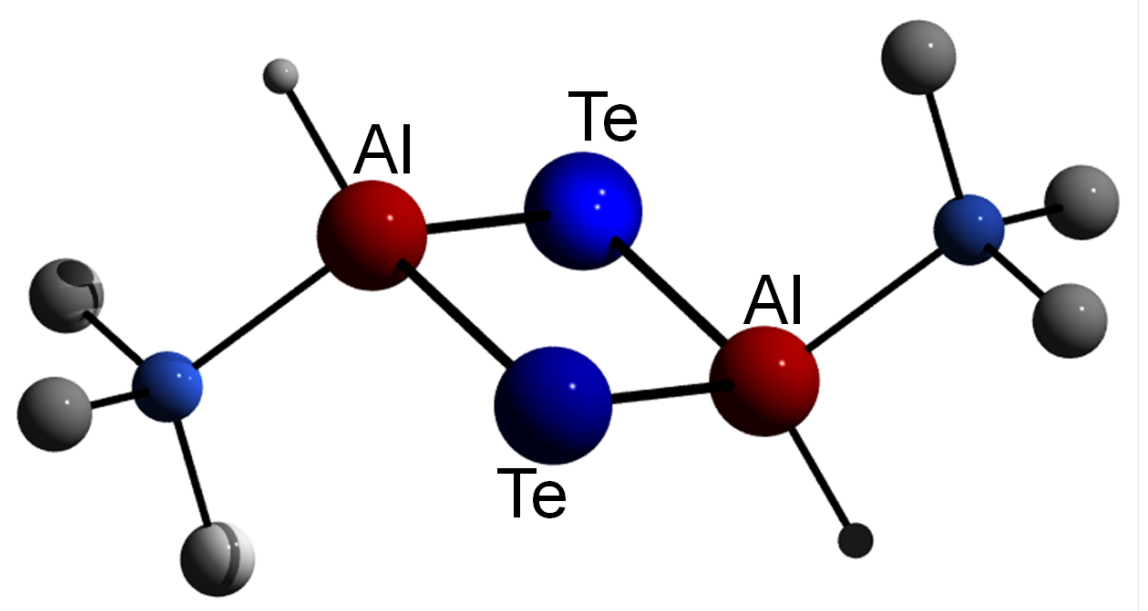

Dimeric complexes of the type [RAlTe $]_{2}$ bearing either a sterically demanding substituent with a side-arm donor [111] or a chelating organic ligand [110, 114] have been prepared. Moreover, the mixed chalcogenide complex trans$\left[\left\{\mathrm{Me}_{3} \mathrm{~N}(\mathrm{PhTe}) \mathrm{Al}(\mu-\mathrm{Se})\right\}_{2}\right]$, featuring a terminal Al-Te single bond, was synthesized by reaction of trans-[ $\left.\left\{\mathrm{Me}_{3} \mathrm{~N}(\mathrm{H}) \mathrm{Al}(\mu-\mathrm{Se})\right\}_{2}\right]$ with diphenylditelluride $\mathrm{Ph}_{2} \mathrm{Te}_{2}$ [119]. The reaction of $\mathrm{Me}_{3} \mathrm{~N}-\mathrm{AlH}_{3}$ with $\mathrm{Ph}_{2} \mathrm{Te}_{2}$ occurred with triple insertion of Te into the Al-H bonds and subsequent formation of $\mathrm{Me}_{3} \mathrm{~N}-\mathrm{Al}(\mathrm{TePh})_{3}$ [120].

Unlike their heavier group 13 counterparts ( $\mathrm{Ga}$ and $\mathrm{In}$ ), which have been prepared and structurally characterized [121], examples of monomeric organoaluminum tellurides RAlTe and containing an $\mathrm{Al}=\mathrm{Te}$ double bond have yet to be reported.

Apart from being structural curiosities, such $\mathrm{Al} / \mathrm{Te}$ intermetallic compounds may reveal of interest as single source precursors for the deposition of $\mathrm{Al}_{2} \mathrm{Te}_{3}$ thin films (via MOCVD), as demonstrated for the Ga and In analogues [122, 123].

Table 8. Selected bond lengths $(\AA)$ and angles $\left(^{\circ}\right)$ of organoaluminum tellurides.

\begin{tabular}{lllll}
\hline Complex & Al-Te & Te-Al-Te & Al-Te-Al & Ref \\
\hline$[\mathrm{t}-\mathrm{Bu} 2 \mathrm{AlTe}(\mathrm{t}-\mathrm{Bu})]_{2}$ & $2.732(3)$ & $93.9(4)$ & $86.1(4)$ & 108 \\
{$[\mathrm{Cp} * \mathrm{AlTe}]_{4}$} & $2.7500(9)$, & $94.84(2)$, & $84.86(2)$, & 116 \\
& $2.6883(9)$, & $96.29(2)$, & $83.68(2)$, & \\
& $2.6917(9)$ & $94.06(2)$ & $85.51(2)$ & \\
{$\left[2-\left(\mathrm{NEt}_{2} \mathrm{CH}_{2}\right)-6-\mathrm{MeC}_{6} \mathrm{H}_{3} \mathrm{AlTe}\right]_{2}$} & $2.581(8)$, & $103.70(3)$ & $76.30(3)$ & 111 \\
& $2.588(7)$ & & & \\
{$\left[\mathrm{N}\left(\mathrm{SiMe}_{3}\right) \mathrm{C}(\mathrm{Ph}) \mathrm{C}\left(\mathrm{SiMe}_{3}\right)_{2} \mathrm{AlTe}\right]_{2}$} & $2.5619(12)$, & $103.12(4)$, & $76.88(4)$, & 110 \\
& $2.5765(14)$, & $102.79(4)$ & $77.21(4)$ & \\
& $2.5768(14)$, & & & \\
& $2.5753(12)$ & & & \\
$\left\{\left[\mathrm{HC}\left\{\mathrm{C}(\mathrm{Me}) \mathrm{N}\left(2,6-\mathrm{i}-\mathrm{Pr}_{2} \mathrm{C}_{6} \mathrm{H}_{3}\right)\right\}_{2}\right] \mathrm{Al}(\mu-\mathrm{E})\right\}_{2}$ & $2.575(3)$, & $97.9(1)$ & $82.1(1)$ & 114 \\
& $2.581(2)$ & & & \\
\hline
\end{tabular}




\begin{tabular}{lllll}
\hline$\left[\mathrm{Me}_{3} \mathrm{~N}(\mathrm{PhTe}) \mathrm{Al}(\mu-\mathrm{Se})\right]_{2}$ & $2.610(2)$ & - & - & 119 \\
{$\left[\mathrm{Me}_{3} \mathrm{~N}(\mathrm{H}) \mathrm{Al}(\mu-\mathrm{Te})\right]_{2}$} & $2.586(4)$, & $103.6(1)$ & $76.4(1)$ & 115 \\
& $2.580(4)$ & & & \\
{$\left[\left(\eta^{1}-3,5-\mathrm{t}-\mathrm{Bu}{ }_{2} \mathrm{pz}(\mu-\mathrm{Al}) \mathrm{H}\right)_{2} \mathrm{Te}_{2}\right.$} & $2.5621(12)$, & - & $69.41(3)$ & 113 \\
& $2.5763(11)$ & & & \\
{$\left[\left(\mathrm{Me}_{3} \mathrm{Si}\right)_{2} \mathrm{CH}\right]_{2} \mathrm{Al}-\mathrm{Te}-\mathrm{Al}\left[\mathrm{CH}\left(\mathrm{SiMe}_{3}\right)_{2}\right]_{2}$} & $2.549(1)$ & - & $110.4(1)$ & 117 \\
& $2.589(2)$, & $111.21(7)$, & - & 120 \\
$\mathrm{Me}_{3} \mathrm{~N}-\mathrm{Al}(\mathrm{TePh})_{3}$ & $2.585(2)$, & $110.47(8)$, & & \\
& $2.581(2)$ & $110.11(7)$ & & \\
&
\end{tabular}

\section{Organoaluminum Complexes with d-Block Metals}

Intermetallic complexes of group 13 metals and transition metals were first investigated by Ziegler and Natta as potentially active complexes in olefin polymerization. The first report on the structural characterization of "[C $\left.\mathrm{Cp}_{2} \mathrm{TiAlEt}_{2}\right]_{2}$ ", a model compound in the Ziegler-Natta catalytic system, claimed that such a complex contains direct Ti-Al bonds [124]. The latter complex along with others, including $\left[\left\{\mathrm{Co}_{3}(\mathrm{CO})_{9}\right\}\left(\mu^{3}-\mathrm{Al}\right)\right][125]$ and $\left[\mathrm{Cp}(\mathrm{CO})_{3} \mathrm{M}-\mathrm{AlMe}_{2}\right](\mathrm{M}=\mathrm{Mo}, \mathrm{W})[126$, 127], were later unambiguously identified to be an hydride-bridged compound $\left.\left[\mathrm{C}_{5} \mathrm{H}_{5}\right)\left(\mathrm{C}_{5} \mathrm{H}_{4}\right) \mathrm{Ti}(\mu-\mathrm{H}) \mathrm{AlEt}_{2}\right]_{2}[128]$ and isocarbonyl-bridged M-CO-Al species, respectively [129-131]. Nevertheless, the interest in this type of intermetallic complexes has remained high since then. Additional impulses came with the development of monovalent group 13 diyles of the type RAl(I), susceptible to act as coordinating Lewis bases toward transition metal complexes. In this area, the report by Robinson et al of a "ferrogallyne" 2,6-Mes* ${ }_{2}-\mathrm{C}_{6} \mathrm{H}_{3} \mathrm{Ga}-\mathrm{Fe}(\mathrm{CO})_{4}(\mathrm{Mes} *=$ 2,4,6-i- $\left.\mathrm{Pr}_{3}-\mathrm{C}_{6} \mathrm{H}_{2}\right)$ containing a very short Fe-Ga bond (2.2248 $\AA$ ) [132] thought to be a $\mathrm{Fe} \equiv \mathrm{Ga}$ triple bond, promoted a very intense debate, yet sometimes regrettably personal, on the nature of bonding in the latter Fe-Ga complex [133,134]. These discussions certainly stimulated the general interest in this class of complexes and several group 13-transition metal complexes were synthesized, structurally characterized in the following years and their bonding properties studied by computational calculations.

The unusual coordination properties of the ligands $\mathrm{ECp}^{*}(\mathrm{E}=\mathrm{Al}, \mathrm{Ga}, \mathrm{In})$ go beyond their isolobal $\mathrm{CO}$ or phosphine analogues. Species of the type $\mathrm{ECp}^{*}$ not only stabilize unprecedented cluster structures, but may significantly influence the chemical reactivity of the resulting cluster complexes. By generating very electron rich and thus unusually reactive transition metal centers, unexpected $\mathrm{C}-\mathrm{H}, \mathrm{Si}-\mathrm{H}$ and even $\mathrm{C}-\mathrm{C}$ bond activation reactions were observed with, for instance, $\left[\mathrm{Ni}\left(\mathrm{AlCp}^{*}\right)_{4}\right] \quad[135], \quad\left[\mathrm{Fe}(\mathrm{AlCp} *)_{5}\right], \quad\left[\mathrm{Ru}(\mathrm{AlCp} *)_{5}\right] \quad[136] \quad$ and $\left[\mathrm{RhCp} *\left(\mathrm{CH}_{3}\right)_{2}\left(\mathrm{GaCp}^{*}\right)\right][137]$. 
Besides their fascinating bonding properties and unusual reactivity, these intermetallic complexes are of potential interest as single source precursors for the thin film deposition (MOCVD process) of alloys such as $\beta$-CoGa [138], $\mathrm{CuAl}_{2}$ and $\alpha / \beta-\mathrm{CuAl}[139], \theta-\mathrm{CuE}_{2}(\mathrm{E}=\mathrm{Al}, \mathrm{Ga})$ and $\mathrm{Cu}_{1-x} \mathrm{Al}_{x}$ phases [140]. Also, such molecular entities may be useful molecular precursors for nanoparticles synthesis in solution, as reported for $\alpha-/ \beta$-NiAl Nanoparticles [141].

The following section summarizes the synthesis, structures and bonding properties of complexes containing at least one direct transition metal-aluminum bond. The metal derivatives incorporating $\mathrm{M}-\mathrm{X}-\mathrm{M}$ bridging organic groups $(\mathrm{X}=$ alkyl, hydride, alkoxides, amides, ...) are excluded.

Synthesis. Numbers of group 13 diyl-transition metal complexes, mostly with gallanediyls $(\mathrm{GaR})$ derivatives, have been prepared and structurally characterized in the last decade, as reviewed by Fischer and others [142-146]. Several general reaction protocols have been established over the past years for the synthesis of such species. In this domain, early studies mainly dealt with reactions of electronrich, often anionic, transition metal complexes with triorganylalanes $\mathrm{AlR}_{3}$, yielding the corresponding adducts of the type $\mathrm{L}_{n} \mathrm{M}-\mathrm{AlR}_{3}$, in which the Lewis basic transition metal complex $\mathrm{L}_{n} \mathrm{M}$ coordinates to the Lewis-acidic alane $\mathrm{AlR}_{3}$ [147150] (Fig. 20a). In addition, salt metathesis reactions between carbonyl metallates and $\mathrm{RAlX}_{2}(\mathrm{X}=\mathrm{Cl}, \mathrm{I})$ [151-154] (Fig. 20b), as well as alkane elimination reactions between transition metal hydrides (containing an acidic $\mathrm{M}-\mathrm{H}$ function) and alanes [148, 155] (Fig. 20c), have been thoroughly studied.

As initially reported by Schnöckel, substitution reactions between monovalent alanediyl RAl species and transition metal carbonyl olefin complexes certainly constitute the most attractive synthetic approach to access M-Al intermetallic complexes [136, 156-163] (Fig. 20d) [26]. Since then, variously substituted RE species $(\mathrm{E}=\mathrm{Al}, \mathrm{Ga}, \mathrm{In})$ have been studied, going from sterically bulky alkyl and aryl groups such as terphenyl ligands $\left(2,4,6-\mathrm{R}_{3} \mathrm{C}_{6} \mathrm{H}_{2} ; 2,4-\mathrm{R}_{2} \mathrm{C}_{6} \mathrm{H}_{3}\right)$ or $\mathrm{C}\left(\mathrm{SiMe}_{3}\right)_{3}$, which are anionic 2-electron substituents, to chelating 4-electron donors such as guanidinato and $\beta$-diketiminato-based ligands. The extent of $\sigma$-donating and $\pi$ accepting properties of these group 13 diyls depends on the nature of the metal center (Al, Ga, In) and the supporting ligand. As a consequence, the structures and chemical properties of the resulting aluminum-transition metal complexes may greatly differ.

In addition to the aforementioned general reaction pathways, complexes containing transition metal-Al bonds have been prepared by rather unusual reactions such as that between $\left[\mathrm{Cp}^{*} \mathrm{Co}\left(\mathrm{C}_{2} \mathrm{H}_{4}\right)_{2}\right]$ and $\left[\mathrm{Et}_{2} \mathrm{AIH}\right]$, resulting in the formation of the bimetallic complex $\left[\left\{\mathrm{Cp}^{*}\left(\eta^{2}-\mathrm{C}_{2} \mathrm{H}_{4}\right)-\mathrm{Co}-\mathrm{Al}\left(\mathrm{C}_{2} \mathrm{H}_{5}\right)\right\}_{2}\right][164]$.

Very recently, a $\mathrm{Cr}(\mathrm{I})$ aminopyridinate species containing a $\mathrm{Cr}-\mathrm{Cr}$ quintuple bond was reported to react with $\mathrm{AlMe}_{3}$ via insertion of the $\mathrm{Cr}-\mathrm{Cr}$ quintuple bond into the Al-Me bond (carbalumination) to form the trimetallic compound $\operatorname{LCr}(\mu-$ $\left.\left.\mathrm{CH}_{3}\right)\left(\mu-\mathrm{AlMe}_{2}\right)\right] \mathrm{CrL} \quad(\mathrm{L}=$ (2,6-diisopropylphenyl)-[6-(2,6-dimethylphenyl)pyridin-2-yl]-amine)[165]. This novel type of complex incorporates a formal Cr- 
$\mathrm{Cr}$ quadruple bond along with formally anionic $\mathrm{Me}$ and $\mathrm{AlMe}_{2}$ groups and features elongated Cr-Al bonds (2.8945(14), 2.9076(14) $\AA$ ).

Fig. 20. Synthesis of aluminum-transition metal complexes

$$
\begin{aligned}
& \mathrm{L}_{\mathrm{n}} \mathrm{M}+\mathrm{AIR}_{3} \longrightarrow \mathrm{ML}_{\mathrm{n}}-\mathrm{AIR}_{3} \\
& {\left[\mathrm{~L}_{n} \mathrm{M}\right] \mathrm{M}^{\prime}+\mathrm{CIAIR}_{2} \underset{-\mathrm{M}^{\prime} \mathrm{Cl}}{\longrightarrow} \mathrm{ML}_{n}-\mathrm{AIR}_{2}} \\
& \begin{array}{ll}
\mathrm{L}_{n} \mathrm{M}-\mathrm{H}+\mathrm{R}^{\prime} \mathrm{AlR} \mathrm{R}_{2} \underset{-\mathrm{R}^{\prime} \mathrm{H}}{\longrightarrow} & \mathrm{ML}_{\mathrm{n}} \longrightarrow \mathrm{R}^{\prime}=\mathrm{H} \text {, alkyl }
\end{array} \\
& {\left[L_{n} M\right] R^{\prime}+A I R \longrightarrow M L_{n}-A^{\prime} R_{2}} \\
& \text { - R' } \quad \mathrm{R}=\mathrm{Cp}^{*}, \text { Nacnac } \\
& \mathrm{R}^{\prime}=\mathrm{CO} \text {, olefin }
\end{aligned}
$$

\begin{tabular}{|c|c|c|}
\hline Complex & $\mathrm{Al}-\mathrm{M}(\AA)$ & Ref \\
\hline \multicolumn{3}{|c|}{ Alane $\left(\mathrm{AlR}_{3}\right)$ complexes } \\
\hline$\left[\mathrm{Cp} *\left(\mathrm{PMe}_{3}\right)\left(\mathrm{H}_{2}\right) \mathrm{Ir}-\mathrm{AlPh}_{3}\right]$ & $2.684(2)$ & 148 \\
\hline$\left[\mathrm{Cp}(\mathrm{CO})_{2} \mathrm{Fe}-\mathrm{AlPh}_{3}\right]\left[\mathrm{NEt}_{4}\right]$ & $2.510(2)$ & 147 \\
\hline$\left[\left(\mathrm{Cy}_{3} \mathrm{P}\right)_{2} \mathrm{Pt}-\mathrm{AlCl}_{3}\right]$ & $2.3857(7)$ & 149 \\
\hline \multicolumn{3}{|c|}{ Alanyle complexes with terminal $A_{1} R_{2}$ groups } \\
\hline$\left[\mathrm{Cp}(\mathrm{CO})_{2} \mathrm{Fe}-\mathrm{Al}(\mathrm{tmp})_{2}\right]$ & $2.450(1)$ & 154 \\
\hline$\left.\left[\mathrm{Cp}(\mathrm{CO})_{2} \mathrm{Fe}-\mathrm{Al}\left(\mathrm{CH}_{2}\right)_{3} \mathrm{NMe}_{2}\right) i-\mathrm{Bu}\right]$ & $2.456(1)$ & 167 \\
\hline \multicolumn{3}{|c|}{ Alanyle complexes with bridging $\mathrm{AlR}_{2}$ groups } \\
\hline$\left.\left[\left\{\left(\mathrm{C}_{5} \mathrm{H}_{4}\right)_{2} \mathrm{MoAl}_{2} \mathrm{Me}_{3}\right]_{2}\right\}\right]$ & $2.685(3), 2.656(3)$ & 168 \\
\hline$\left.\left[\left(\mathrm{C}_{5} \mathrm{H}_{5}\right)\left(\mathrm{C}_{5} \mathrm{H}_{4}\right)\right]_{2}(\mathrm{H}) \mathrm{MoAl}_{3} \mathrm{Me}_{5}\right]$ & 2.650(5), 2.657(4), 2.951(4), 2.996(5) & 168 \\
\hline$\left.\left[\left(\mathrm{C}_{5} \mathrm{H}_{5}\right)\left(\mathrm{C}_{5} \mathrm{H}_{4}\right)\right]_{2}(\mathrm{H}) \mathrm{MoAl}_{3} \mathrm{Me}_{5}\right]$ & 2.662(6), 2.655(5), 2.944(6), 3.003(6) & 169 \\
\hline $\begin{array}{l}{\left[\left\{\left(\mathrm{C}_{5} \mathrm{H}_{4} \mathrm{Me}\right)\left(\mu-\eta^{1}: \eta^{5}-\mathrm{C}_{5} \mathrm{H}_{3} \mathrm{Me}\right) \mathrm{Mo}(\mu-\right.\right.} \\
\mathrm{Al}(\mathrm{H}) i-\mathrm{Bu})\end{array}$ & $2.636(2), 2.944(2)$ & 155 \\
\hline$\left[\mathrm{L}_{2} \mathrm{Cr}_{2}\left(\mu-\mathrm{CH}_{3}\right)\left(\mu-\mathrm{AlMe}_{2}\right)\right]$ & $2.8945(14), 2.9076(14)$ & 165 \\
\hline \multicolumn{3}{|c|}{ Homoleptic alylene complexes with terminal alanediyls (AlR) } \\
\hline$\left[\mathrm{Pd}\left(\mathrm{AlCp}^{*}\right)_{4}\right]$ & $2.2950(9)$ & 161 \\
\hline$\left[\mathrm{Ni}(\mathrm{AlCp} *)_{4}\right]$ & $2.1727(8)$ & 161 \\
\hline
\end{tabular}

Structure and Bonding. A large variety of intermetallic complexes containing terminal alanes $\mathrm{AlR}_{3}$, terminal and bridging alanyls $\mathrm{AlR}_{2}$ as well as terminal and bridging alanediyls AlR has been structurally characterized (see table 9).

Table 9. M-Al bond lengths $(\AA)$ in organoaluminum complexes with d-block metals. 


\begin{tabular}{|c|c|c|}
\hline$\left[\mathrm{Fe}(\mathrm{AlCp} *)_{5}\right]^{\mathrm{a}}$ & $\begin{array}{l}2.2124(15), 2.2419(15), 2.2404(15) \\
2.3686(15), 2.3272(14)\end{array}$ & 136 \\
\hline$\left[\mathrm{Fe}(\mathrm{AlCp} *)_{5}\right]^{\mathrm{a}}$ & $2.223,2.378,2.405, \mathrm{Fe} 1-\mathrm{A} 14$ 2.444, 2.263 & 136 \\
\hline$\left[\mathrm{Ru}(\mathrm{AlCp} *)_{5}\right]^{\mathrm{b}}$ & $2.294(2), 2.331(2), 2.337(2), 2.49(3), 2.434(2)$ & 136 \\
\hline \multicolumn{3}{|c|}{ Heteroleptic alylene complexes with terminal alanediyls (AlR) } \\
\hline$\left[(\mathrm{CO})_{4} \mathrm{Fe}\left(\mathrm{AlCp}^{*}\right)\right]$ & $2.231(3)$ & 152 \\
\hline$\left[(\mathrm{CO})_{5} \mathrm{Cr}\left(\mathrm{AlCp}^{*}\right)\right]$ & $2.3761(6)$ & 158 \\
\hline$\left[(\mathrm{dcpe}) \operatorname{Pt}(\mathrm{AlCp} *)_{2}\right]$ & $2.327(2), 2.335(2)$ & 159 \\
\hline$[(\mathrm{dvds}) \operatorname{Pd}\{\mathrm{Al}(\mathrm{ddp})\}]$ & $2.3702(10)$ & 163 \\
\hline$\left[\left(\mathrm{Cp}^{*} \mathrm{Al}\right)_{3} \mathrm{Ni}\left(\mu^{2}-\mathrm{H}\right) \mathrm{Al}(\mathrm{Ph}) \mathrm{Cp}^{*}\right]$ & $\begin{array}{l}2.2105(11), 2.2062(10), 2.1688(11), \\
2.2912(11)\end{array}$ & 135 \\
\hline$\left[\left(\mathrm{Cp}^{*} \mathrm{Al}\right)_{3} \mathrm{Ni}(\mathrm{H}) \mathrm{SiEt}_{3}\right]$ & $2.203(8), 2.208(10), 2.180(7)$ & 135 \\
\hline$\left[(\right.$ DippNanacAl $) \mathrm{Pd}_{2}\left(\mu^{2}-\mathrm{GaCp}^{*}\right)_{2}\left(\mathrm{GaCp}^{*}\right.$ & $2.456(3), 2.559(3)$ & 162 \\
\hline \multicolumn{3}{|c|}{ Base-stabilized heteroleptic alylene complexes with terminal alanediyls (AlR) } \\
\hline$\left[(\mathrm{CO})_{5} \mathrm{~W}-\mathrm{Al}(t-\mathrm{Bu})(\mathrm{tmpda})\right]$ & $2.741(4)$ & 153 \\
\hline$\left[(\mathrm{CO})_{5} \mathrm{Cr}-\mathrm{Al}(\mathrm{Cl})(\mathrm{tmpda})\right]$ & $2.482(1)$ & 153 \\
\hline$\left[(\mathrm{CO})_{5} \mathrm{~W}-\mathrm{Al}(\mathrm{Et})(\mathrm{tmeda})\right]$ & $2.670(1)$ & 166 \\
\hline$[\mathrm{CO})_{5} \mathrm{~W}-\mathrm{Al}[(\mathrm{Cl})(\mathrm{tmpda})]$ & $2.645(2)$ & 166 \\
\hline \multicolumn{3}{|c|}{ Alylene complexes with bridging alanediyls (AlR) } \\
\hline$\left[(\mathrm{CpNi})_{2}\left(\mu^{2}-\mathrm{AlCp}^{*}\right)_{2}\right]$ & $2.274(2), 2.283(2)$ & 156 \\
\hline$\left[(\mathrm{CO})_{6} \mathrm{Co}_{2}\left(\mu^{2}-\mathrm{AlCp}^{*}\right)_{2}\right]$ & $2.384(3), 2.369(3) / 2.377$ & 157 \\
\hline$\left[\mathrm{Pt}_{2}\left(\mathrm{GaCp}^{*}\right)_{2}\left(\mu^{2}-\mathrm{AlCp}^{*}\right)_{3}\right]$ & $2.3310(7), 2.4259(16), 2.4237(17)$ & 160 \\
\hline$\left[\{\operatorname{Pd}(\mathrm{dvds})\}_{2}\left\{\mu^{2}\right.\right.$-AlDippNacnac $\left.\}\right]$ & $2.4234(18), 2.4419(18)$ & 162 \\
\hline$\left[\left\{\mathrm{Cp} * \operatorname{Ir}\left(\mathrm{PMe}_{3}\right)\left(\mu^{2}-\mathrm{AlEt}\right)\right\}_{2}\right]$ & $2.456(1), 2.459(1)$ & 148 \\
\hline$\left[\left\{\mathrm{Cp}^{*}\left(\eta^{2}-\mathrm{C}_{2} \mathrm{H}_{4}\right) \mathrm{Co}(\mu-\mathrm{AlEt})\right\}_{2}\right]$ & $2.336(2), 2.333(1)$ & 164 \\
\hline$\left.\left[\mathrm{CpFe}(\mathrm{CO})_{2}\right]_{2} \mathrm{Al}\left(2-\mathrm{Me}_{2} \mathrm{NCH}_{2} \mathrm{C}_{6} \mathrm{H}_{4}\right)\right]$ & $2.468(1), 2.496(1)$ & 151 \\
\hline \multicolumn{3}{|c|}{ Alylene complexes with terminal and bridging alanediyls (AlR) } \\
\hline$\left[\mathrm{Pd}_{3}\left(\mathrm{AlCp}^{*}\right)_{2}\left(\mu^{2}-\mathrm{AlCp}^{*}\right)_{2}\left(\mu^{3}-\mathrm{AlCp}^{*}\right)_{2}\right]$ & $\begin{array}{l}2.592(5), 2.498(5), 2.563(5), 2.488(5) \\
2.401(5), 2.369(5)\end{array}$ & 160 \\
\hline$\left[\mathrm{Pd}_{2}\left(\mathrm{AlCp}^{*}\right)_{2}\left(\mu^{2}-\mathrm{AlCp}^{*}\right)_{3}\right]$ & $2.3230(18), 2.4559(18), 2.4559(18)$ & 160 \\
\hline
\end{tabular}

${ }^{\text {a }}$ Two $\mathrm{C}-\mathrm{H}$ activated isomers containg a $\mu^{2}$-bridging $\mathrm{Fe}-\mathrm{H}-\mathrm{Al}$ unit.

${ }^{\mathrm{b}} \mathrm{C}-\mathrm{H}$ activated isomer containg a $\mu^{2}$-bridging $\mathrm{Ru}-\mathrm{H}-\mathrm{Al}$ unit.

As stated above, alane complexes of the type $\mathrm{L}_{n} \mathrm{M}-\mathrm{AlR}_{3}$ have typically been prepared via reaction between Lewis basic, often anionic, transition metal carbonyl complexes and $\mathrm{AlR}_{3}$. The formation of a direct M-Al bond or an isocyanatebridge $\mathrm{M}-\mathrm{CO}-\mathrm{Al}$ strongly depends on the Lewis basicity of the transition metal complex, and thus on the nature of the metal center and on the electronic properties of its supporting ligands [147]. Comparisons of the structural parameters of complexes containing the same metal centers lack from the limited number of structurally characterized complexes. However, the M-Al bond lengths of alane 
complexes $\mathrm{L}_{\mathrm{n}} \mathrm{M}-\mathrm{AlR}_{3}$ such as anionic $\left[\mathrm{Cp}(\mathrm{CO})_{2} \mathrm{Fe}-\mathrm{AlPh}_{3}\right]^{-}(2.510(2) \AA)$ are typically slightly longer than those of alanyle complexes $\mathrm{L}_{\mathrm{n}} \mathrm{M}-\mathrm{AlR}_{2}$ containing terminal bonded alanyl moieties (e.g. $\left[\mathrm{Cp}(\mathrm{CO})_{2} \mathrm{Fe}-\mathrm{Al}(\mathrm{tmp})_{2}\right] 2.450(1) \AA,\left[\left(\eta^{5}-\right.\right.$ $\left.\left.\left.\left.\mathrm{C}_{5} \mathrm{H}_{5}\right)(\mathrm{CO})_{2} \mathrm{Fe}-\mathrm{Al}\left(\mathrm{CH}_{2}\right)_{3} \mathrm{NMe}_{2}\right) i-\mathrm{Bu}\right] 2.456(1) \AA\right)$ as well as alylene complexes with bridging alanediyl groups $\left[\mathrm{L}_{n} \mathrm{M}\right]_{2} \mu^{2}-\mathrm{AlR}$ (e.g. $\left[\mathrm{CpFe}(\mathrm{CO})_{2}\right]_{2} \mathrm{Al}(2-$ $\left.\left.\mathrm{Me}_{2} \mathrm{NCH}_{2} \mathrm{C}_{6} \mathrm{H}_{4}\right)\right]$ 2.468(1), 2.496(1) $\AA$ ). Homoleptic $\mathrm{M}(\mathrm{AlR})_{\mathrm{x}}$ and heteroleptic alylene complexes $\mathrm{L}_{\mathrm{n}} \mathrm{M}-\mathrm{AlR}$ with terminal alanediyl groups such as $\left[\mathrm{Fe}(\mathrm{AlCp} *)_{5}\right]$ and $\left[(\mathrm{CO})_{4} \mathrm{Fe}(\mathrm{AlCp} *)\right]$ typically show significantly shorter intermetallic bonds. The only exception was observed in the alane complex $\left(\mathrm{Cy}_{3} \mathrm{P}\right)_{2} \mathrm{Pt}-\mathrm{AlCl}_{3}$ (2.3857(7) $\AA$ ), whose $\mathrm{Pt}-\mathrm{Al}$ bond lengths is comparable to that observed in the alylene complexes with terminal alanediyl moiety $\left[(\mathrm{dcpe}) \mathrm{Pt}\left(\mathrm{AlCp}^{*}\right)_{2}\right](\mathrm{dcpe}=1,2-$ bis(dicyclohexylphosphanyl)ethane), 2.327(2), 2.335(2) Å).

Fig. 21. Solid state structure of $\left(\mathrm{Cy}_{3} \mathrm{P}\right)_{2} \mathrm{Pt}-\mathrm{AlCl}_{3}$ 


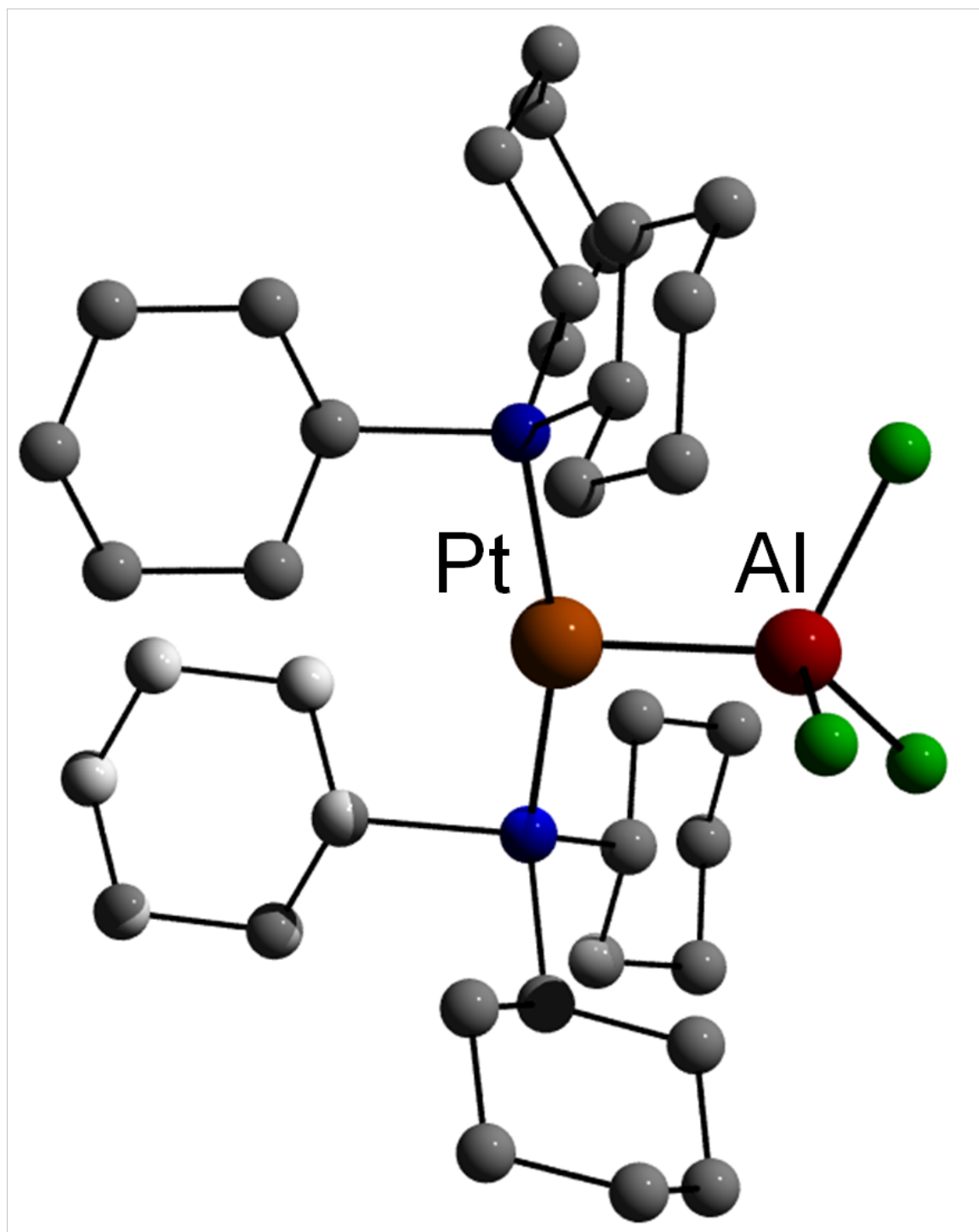

The bonding situation in $\mathrm{L}_{n} \mathrm{M}-\mathrm{AlR}_{3}$ is best described as that of a simple adduct between the Lewis-basic transition metal complexes coordinated to the Lewisacidic alane, as shown by computational calculations [170]. For instance, the geometry of compound $\mathrm{Cp}^{*}\left(\mathrm{PMe}_{3}\right) \operatorname{Ir}(\mathrm{H})_{2} \mathrm{AlPh}_{3}$ indicates that the $\mathrm{Ir}$ center in $\mathrm{Cp} *\left(\mathrm{PMe}_{3}\right) \mathrm{Ir}$ is Lewis basic, forming a dative two-electron bond to the aluminum center. This finding strongly contrasts with the bonding situation observed in alylene complexes such as $\left[(\mathrm{CO})_{4} \mathrm{Fe}(\mathrm{AlCp} *)\right]$, where the electron transfer goes from the Lewis basic, two-electron donor alanediyl $\mathrm{Cp}^{*} \mathrm{Al}$ to the electron deficient $\mathrm{Fe}(\mathrm{CO})_{4}$ fragment [148]. 
Terminally-bound alanyle complexes of the type $\mathrm{L}_{n} \mathrm{M}-\mathrm{AlR}_{2}$ contain an electron-deficient $\mathrm{Al}$ center that, in principle, may act as a Lewis acid moiety. Such complexes therefore tend to form intra- or intermolecularly coordinated structures as observed in base-stabilized complexes such as $\left[\left(\eta^{5}-\mathrm{C}_{5} \mathrm{H}_{5}\right)(\mathrm{CO})_{2} \mathrm{Fe}-\right.$ $\left.\left.\mathrm{Al}\left(\mathrm{CH}_{2}\right)_{3} \mathrm{NMe}_{2}\right) i-\mathrm{Bu}\right]$ and in dimeric complexes such as $\left[\left\{\left(\mathrm{C}_{5} \mathrm{H}_{4} \mathrm{Me}\right)\left(\mu-\eta^{1}: \eta^{5}-\right.\right.\right.$ $\left.\mathrm{C}_{5} \mathrm{H}_{3} \mathrm{Me}\right) \mathrm{Mo}(\mu-\mathrm{Al}(\mathrm{H}) i-\mathrm{Bu})$. Compound $\left[\mathrm{Cp}(\mathrm{CO})_{2} \mathrm{Fe}-\mathrm{Al}(\mathrm{tmp})_{2}\right]$ is the only structurally characterized alanyle complex containing a planar and three-coordinate $\mathrm{Al}$ center.

Fig. 22. Solid state structure of $\left[\mathrm{Cp}(\mathrm{CO})_{2} \mathrm{Fe}-\mathrm{Al}(\mathrm{tmp})_{2}\right]$

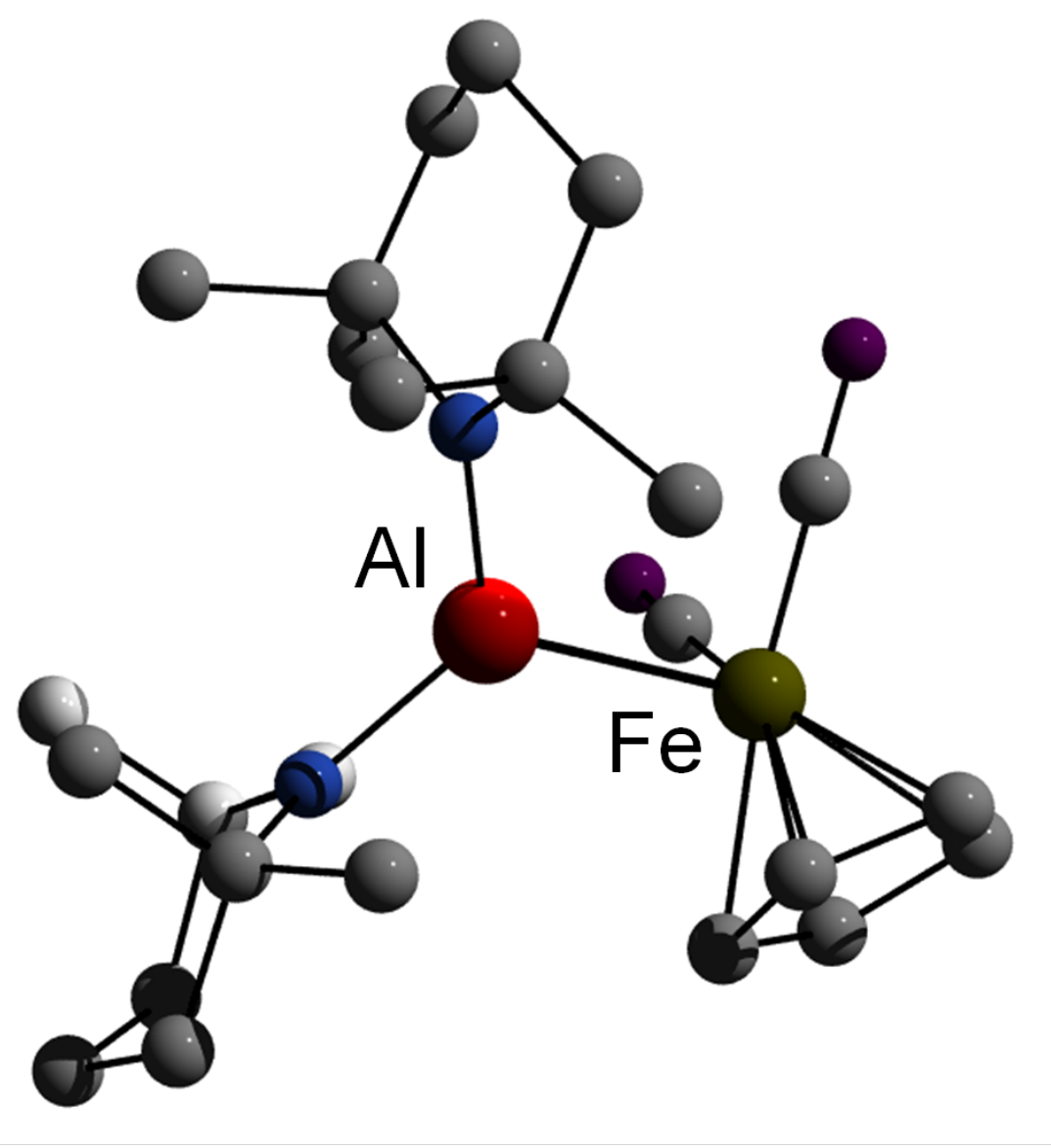

Thus far reported homoleptic transition metal alylene complexes of the type $\left[\mathrm{M}(\mathrm{AlCp})_{\mathrm{x}}\right]$, which contain terminal alanediyls $\mathrm{Cp} * \mathrm{Al}$, incorporate up to four $\mathrm{Cp} * \mathrm{Al}$ moieties acting as ligands toward transition metal centers. This has been observed with $\mathrm{d}^{10}$ metal complexes through the synthesis of $\left[\mathrm{Ni}(\mathrm{AlCp} *)_{4}\right]$ and 
$\left[\mathrm{Pd}(\mathrm{AlCp})_{4}\right]$. For the $\mathrm{d}^{8}$ metal complexes, attempted preparations of the $\left[\mathrm{Fe}(\mathrm{AlCp})_{5}\right]$ and $\left[\mathrm{Ru}(\mathrm{AlCp})_{5}\right]$ derivatives, for which a trigonal bipyramidal structure was predicted [13], only yielded undesired $\mathrm{C}-\mathrm{H}$ activation products. The hypothetic structure $\left[\mathrm{Fe}(\mathrm{AlCp})_{5}\right]$ containing five $\mathrm{Fe}-\mathrm{Al}$ bonds and bearing unactivated and terminal $\mathrm{Cp}^{*}$ ligands appears unrealistic [136].

In contrast, compound $\left[\left(\mathrm{Ph}_{3} \mathrm{P}\right)_{4} \mathrm{RuCl}_{2}\right]$ reacts with six equivalents $\mathrm{GaCp} *$ to afford $\left[\mathrm{Ru}\left(\mathrm{GaCp}^{*}\right)_{6} \mathrm{Cl}_{2}\right]$, in which the $\mathrm{Ru}(\mathrm{II})$ center is surrounded by six $\mathrm{GaCp}$ * moieties and two bridging chloride ligands connect the two Ga centers to one another, hence blocking any $\mathrm{C}-\mathrm{H}$ activation reactions [171]. The formation of $\left[\mathrm{Ru}(\mathrm{AlCp} *)_{5}\right]$ from $\left[\left(\mathrm{Ph}_{3} \mathrm{P}\right)_{4} \mathrm{RuCl}_{2}\right]$ results from the substitution of four phosphine ligands by four $\mathrm{Cp}^{*} \mathrm{Ga}$ ligands, while two $\mathrm{Cp}^{*} \mathrm{Ga}$ groups insert into the $\mathrm{Ru}-\mathrm{Cl}$ bonds.

Fig. 23. Solid state structure of $\left[\mathrm{Pd}(\mathrm{AlCp} *)_{4}\right]$

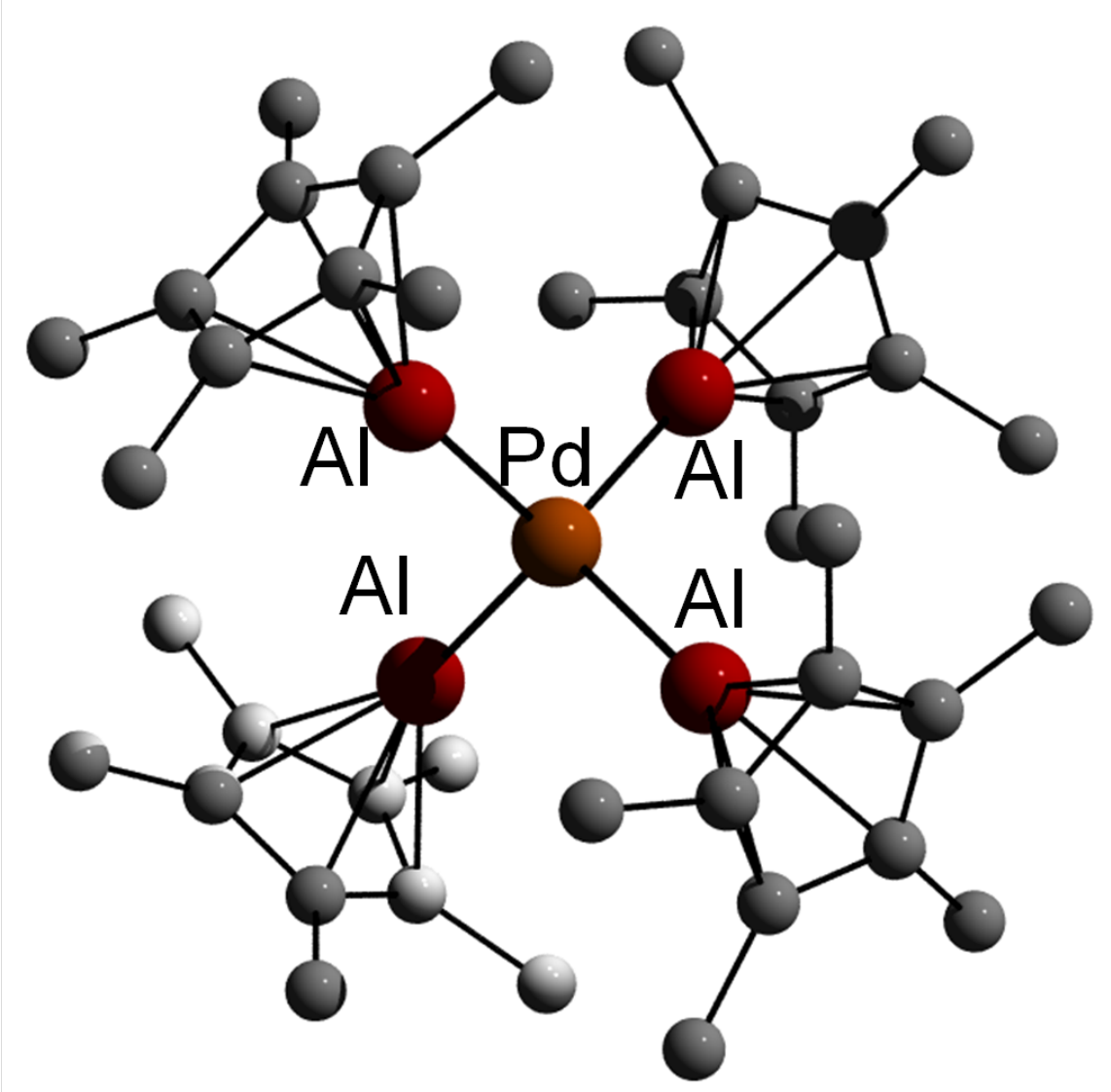

In addition to homoleptic complexes, a large number of heteroleptic alylene complexes of the type $\mathrm{L}_{\mathrm{n}} \mathrm{M}(\mathrm{AlR})_{\mathrm{x}}$ have been structurally characterized, with the 
aluminum center bearing a $\mathrm{Cp}^{*}$, a $\beta$-diketiminate or an alkyl ligand. Lewis-base stabilized heteroleptic complexes of the type $\mathrm{L}_{n} \mathrm{M}-\mathrm{ECl}$ (base) have also been reported. Unlike $\mathrm{Cp}^{*} \mathrm{Al}$ complexes, where the $\mathrm{M}-\mathrm{Al}-\mathrm{Cp}^{*}$ moiety is almost linear, the $\mathrm{M}-\mathrm{Al}-\mathrm{X}$ angle significantly deviates from linearity moiety in base stabilized complexes such as $\left[(\mathrm{CO})_{5} \mathrm{~W}-\mathrm{Al}(\mathrm{Et})(\mathrm{tmeda})\right] \quad\left(121.4(2)^{\circ}\right)$ and $[\mathrm{CO})_{5} \mathrm{~W}-$ $\mathrm{Al}[(\mathrm{Cl})(\mathrm{tmpda})]\left(124.2(1)^{\circ}\right)$. According to theoretical calculations, the dissociation energies $\left(\mathrm{D}_{\mathrm{e}}\right)$ of the $\mathrm{W}-\mathrm{Al}$ bond in species of the type $\left[(\mathrm{OC})_{5} \mathrm{~W}-\mathrm{AlX}\left(\mathrm{NH}_{3}\right)_{2}\right]$ $(\mathrm{X}=\mathrm{H} 100.9 \mathrm{kcal} / \mathrm{mol}, \mathrm{Cl} 93.1 \mathrm{kcal} / \mathrm{mol}$ ) essentially depend on the nature of the $\mathrm{Al}-X$ substituent. Replacement of a hydride by a chloride increases the s-character of the Al-based electron lone pair, which decreases donor-acceptor interactions. This goes along with a weakening of the Al-W bond strength because the Albased donor orbital is more compact. Yet, the W-Al bond in $\left[(\mathrm{OC})_{5} \mathrm{~W}-\right.$ $\left.\mathrm{AlCl}\left(\mathrm{NH}_{3}\right)_{2}\right]$ is shorter than that in $\left[(\mathrm{OC})_{5} \mathrm{~W}-\mathrm{AlH}\left(\mathrm{NH}_{3}\right)_{2}\right]$. Comparable trends were experimentally observed for $[\mathrm{CO})_{5} \mathrm{~W}-\mathrm{Al}[(\mathrm{Cl})(\mathrm{tmpda})](2.645(2) \AA)$ and $\left[(\mathrm{CO})_{5} \mathrm{~W}-\mathrm{Al}(\mathrm{Et})(\mathrm{tmeda})\right](2.670(1) \AA)$ [166].

The bonding properties of the presently discussed alylene complexes have been exhaustively studied via quantum chemical calculations. Monovalent group 13 diyls $\mathrm{RE}$ are formally isolobal with carbon monoxide $\mathrm{CO}$, phosphanes $\mathrm{PR}_{3}$ and singlet carbenes $\mathrm{CR}_{2}$. Since the $\mathrm{HOMO}$ of $\mathrm{Cp} * \mathrm{E}$ predominantly consists of a large lobe on $\mathrm{E}$ pointing away from the $\mathrm{Cp} *$ ligand, $\mathrm{Cp}{ }^{*} \mathrm{E}$-type species exhibit $\sigma$-donor properties as already mentioned. Moreover, the presence of two orthogonal and degenerate LUMOs, which are $\pi$-antibonding with respect to the $\mathrm{Cp}^{*}-\mathrm{E}$ bond, should in principle allow for $\pi$-acceptor properties. However, numerous theoretical calculations both on neutral and cationic transition metal complexes of group 13 diyls $\mathrm{ER}(\mathrm{E}=\mathrm{B}-\mathrm{Tl} ; \mathrm{R}=\mathrm{H}$, alkyl, aryl, $\mathrm{Cp}$, silyl, amide, halide) clearly demonstrated that the diyls ER are strong $\sigma$-donating Lewis bases with rather weak $\pi$-accepting properties. As expected, the nature of the supporting ligand directly influences the donating/accepting abilities of the metal center. For instance, $\beta$-diketiminato-substituted diyls were found to be more Lewis basic than $\mathrm{Cp}^{*}$ substituted diyls, which is most likely due to the increased negative charge at the gallium atom on the latter $[9,12,13,159,166,172-176]$. However, an in-depth analysis of the bonding situation in these complexes revealed that ionic contributions may also play an important role in the stability of these bimetallic entities. For instance, while the $\mathrm{Al}-\mathrm{Fe}$ bond in $\left[(\mathrm{CO})_{4} \mathrm{Fe}(\mathrm{AlCp} *)\right][152]$ was initially described as a simple donor-acceptor single bond between the $\mathrm{Al}(\mathrm{I})$ center and the $\mathrm{Fe}(0)$ atom, subsequent DFT calculations were consistent with a more polar Fe-Al bond $\left(\mathrm{RAl}^{2+} \mathrm{Fe}(\mathrm{CO}){ }_{4}{ }^{2-}\right)$ arising from a significant electron transfer from the $\mathrm{Al}$ atom to the transition metal center [157]. 


\section{Organoaluminum Complexes with f-Block Metals}

Unlike their well-established p- and d-block analogues, f-block metal complexes with direct f-element-Al metal bonds remain extremely rare. However, interest in such derivatives has been growing in recent years and initial results on that matter have been recently reviewed [177,178].

The first complexes containing group 13 metal-f-element bonds were reported in 2006 [179]. Lewis acid-base adducts of the type $\left[\mathrm{Cp}^{*}{ }_{2} \operatorname{Ln}(\mathrm{AlCp} *)\right](\mathrm{Ln}=\mathrm{Eu}$ or $\mathrm{Yb}$ ) with direct aluminum(I)-lanthanide(II) bonds were prepared via a solvent-free route involving the reaction of $\left[\mathrm{Cp}^{*} \mathrm{Al}\right]_{4}$ with a divalent lanthanocene $\mathrm{Cp}^{*}{ }_{2} \mathrm{Ln}(\mathrm{Ln}$ $=\mathrm{Eu}, \mathrm{Yb})$ in an evacuated glass ampule at $120{ }^{\circ} \mathrm{C}$. Both lanthanide products dissociate in solution, indicating rather weak donor-acceptor interactions. The oxidation states of the metal centers are consistent with those of the starting cmplexes. DFT studies showed that the aluminum- $4 \mathrm{f}$-element bond in these adducts (about $30 \mathrm{~kJ} / \mathrm{mol}$ ) is essentially electrostatic with little charge transfer and covalent contributions.

Fig. 24. Synthesis of complexes containing group 13/4-f metal bonds

$$
\begin{aligned}
& \mathrm{Cp}^{*}{ }_{2} \mathrm{M}+\mathrm{Cp}^{*} \mathrm{Al} \longrightarrow \mathrm{Cp}^{*}{ }_{2} \mathrm{M}\left(\mathrm{AlCp}^{*}\right) \\
& \mathrm{M}=\mathrm{Yb}, \mathrm{Eu} \\
& \mathrm{Cp}^{*}{ }_{2} \mathrm{M}+\mathrm{Cp}^{*} \mathrm{Ga} \longrightarrow \mathrm{Cp}^{*}{ }_{2} \mathrm{M}\left(\mathrm{GaCp}^{*}\right)_{\mathrm{x}} \\
& M=Y b, x=1 ; E u, x=2
\end{aligned}
$$

Fig. 25. Solid state structure of $\left[\mathrm{Cp} *{ }_{2} \mathrm{Eu}(\mathrm{AlCp} *)\right]$ 


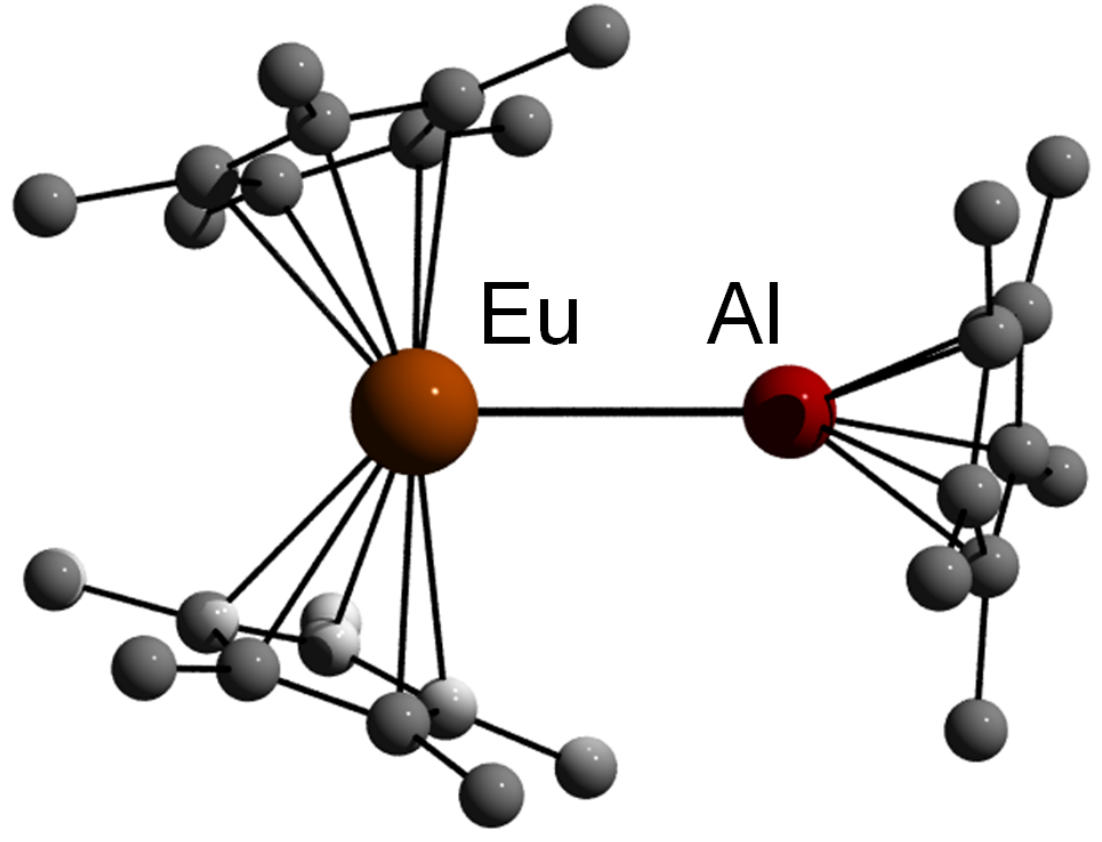

Fig. 26. Solid state structure of $\left[\mathrm{Cp} *{ }_{2} \mathrm{Eu}(\mathrm{GaCp} *)_{2}\right]$ 


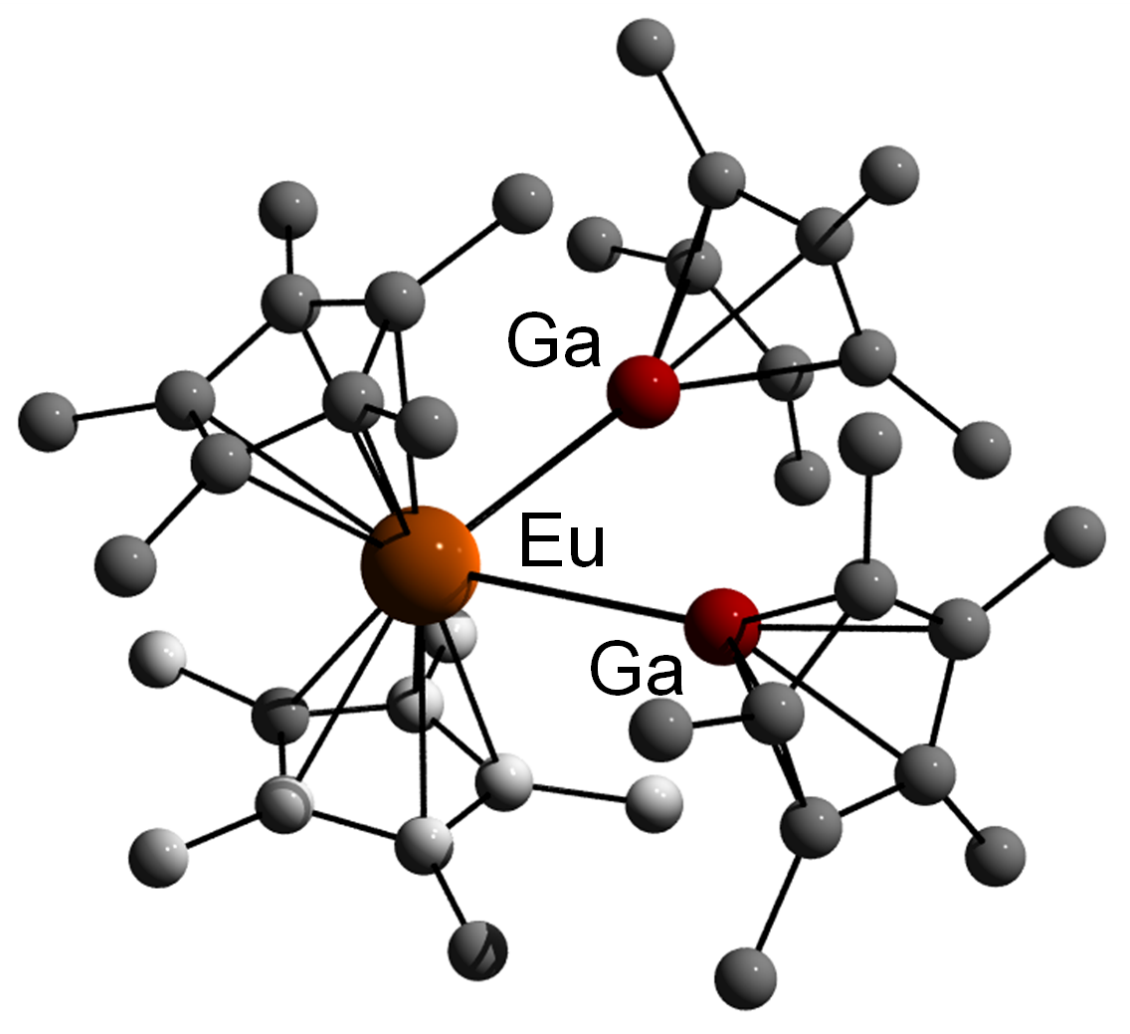

In addition, the formation of adduct complexes upon reaction of trivalent lanthanides with $\mathrm{Cp} * \mathrm{E}(\mathrm{E}=\mathrm{Al}, \mathrm{Ga})$ was proven experimentally. $\left(\mathrm{CpSiMe}_{3}\right)_{3} \mathrm{Ce}-\mathrm{ECp}^{*}$ complexes were observed in solution by variabletemperature paramagnetic NMR spectroscopy. Computational calculations using the model complexes $\mathrm{Cp}_{3} \mathrm{Ln}-\mathrm{ECp}(\mathrm{Ln}=\mathrm{La}-\mathrm{Lu} ; \mathrm{E}=\mathrm{Al}, \mathrm{Ga})$ agree with shorter Ln-E bond distances across the Ln series. In addition, these theoretical studies suggest the Ln-E bond to be stronger for Al vs. Ga adduct, unlike earlier reports on divalent lanthanide analogous complexes. Also, the $\mathrm{Nd}-\mathrm{Al}$ bond dissociation energy (BDE) was found to be lower than the energy required (per $\mathrm{Al}$ ) to disrupt the competitively formed $\left(\mathrm{Cp}^{*} \mathrm{Al}\right)_{4}$ tetramer. Therefore $\left(\mathrm{CpSiMe}_{3}\right)_{3} \mathrm{Nd}-\mathrm{AlCp} *$ was predicted to be non-isolable. The highest BDE was calculated for the $\mathrm{CpE}-\mathrm{Gd}$ donor-acceptor interaction. According to these calculations, the Ln-E bonding interactions are predominantly covalent with a nonpolar donor-acceptor character; the formation of a strong covalent bond is not observed because of resistance to reduction of an effectively divalent Ln center [183].

Group 13-actinide complexes have been even less studied thus far than lanthanide complexes. The U-Al compound $\left[\left(\mathrm{CpSiMe}_{3}\right)_{3} \mathrm{U}\left(\mathrm{AlCp}{ }^{*}\right)\right]$, arising from the re- 
action of $\mathrm{Cp}^{*} \mathrm{Al}$ with $\left(\mathrm{CpSiMe}_{3}\right)_{3} \mathrm{U}$, constitutes the first structurally characterized U-Al complex [184].

Fig. 27 Synthesis of groupg 13 diyl-uranium complexes

$$
\begin{aligned}
\left(\mathrm{CpSiMe}_{3}\right)_{3} \mathrm{M}+\mathrm{Cp}^{*} \mathrm{E} \longrightarrow & \left(\mathrm{CpSiMe}_{3}\right)_{3} \mathrm{U}\left(\mathrm{ECp}^{*}\right) \\
\mathrm{M}=\mathrm{Al}, \mathrm{Ga} &
\end{aligned}
$$

In compound $\left[\left(\mathrm{CpSiMe}_{3}\right)_{3} \mathrm{U}(\mathrm{AlCp} *)\right]$ (Fig. 27), the U-Al bond lengths of two crystallographically inequivalent molecules (3.117(3), 3.124(4) $\AA$ ) are very close to the sum of the covalent radii. The calculated natural charge of the AlCp fragment $(0.540,0.560)$ proves a small Al-U net charge transfer of 0.091 . The Wiberg bond index between $\mathrm{U}$ and $\mathrm{Al}$ indicates a covalent bond order of ca. 0.5 .

Fig. 28 Solid state structure of $\left[\left(\mathrm{CpSiMe}_{3}\right)_{3} \mathrm{U}\left(\mathrm{AlCp}^{*}\right)\right]$

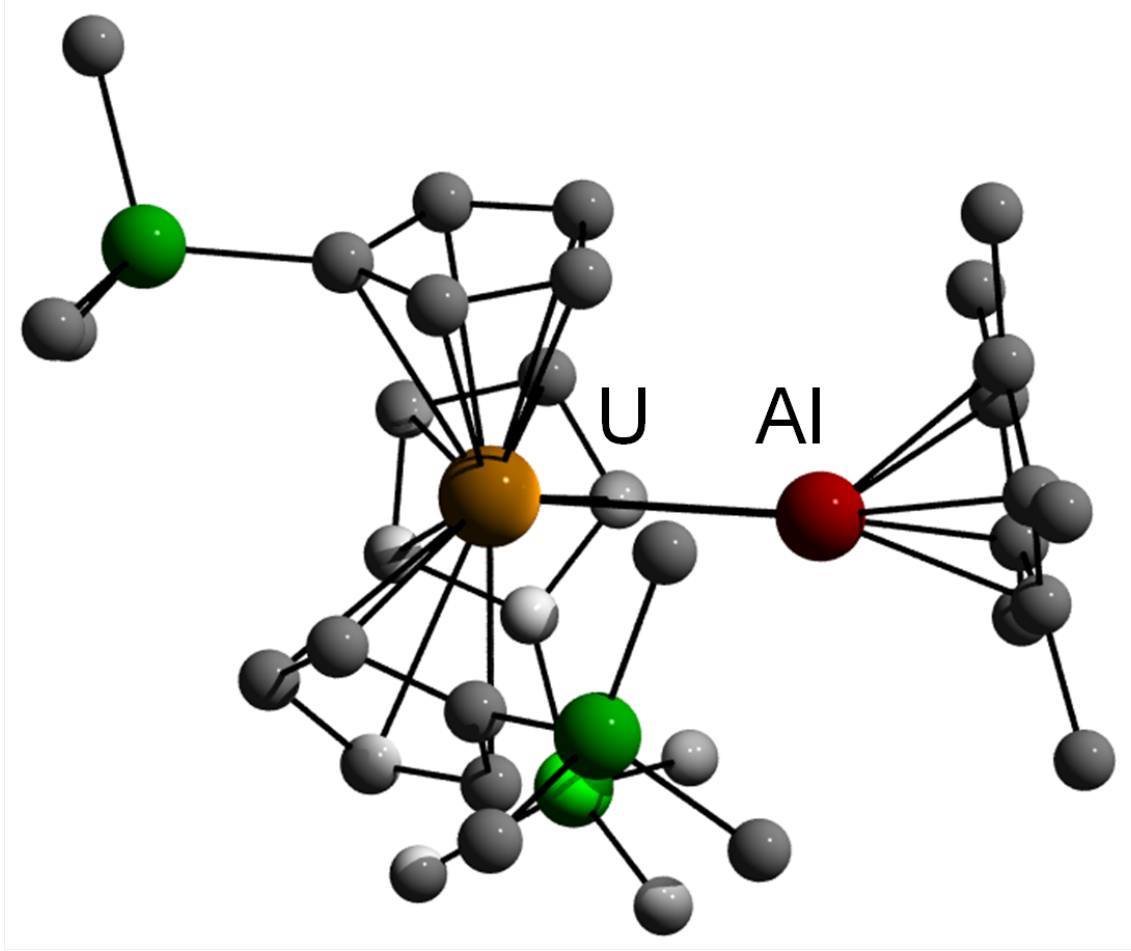

Arnold et al also performed theoretical calculations to compare intermetallic group 13 metal complexes of $4 \mathrm{f}$ and $5 \mathrm{f}$ metals, these being synthesized by reaction of $\left(\mathrm{CpSiMe}_{3}\right)_{3} \mathrm{Nd}$ and $\left(\mathrm{CpSiMe}_{3}\right)_{3} \mathrm{U}$ with $\mathrm{Cp} * \mathrm{E}(\mathrm{E}=\mathrm{Al}, \mathrm{Ga})$ [185]. While the uranium complexes were isolated on gram scales and characterized by single crystal $\mathrm{X}$-ray diffraction, the $\mathrm{Nd}$ analogues were only observed spectroscopically. DFT 
calculations revealed that $\mathrm{Cp} * \mathrm{Al}$ is a slightly better donor than $\mathrm{Cp} \mathrm{p}^{*} \mathrm{Ga}$, while $\mathrm{U}$ is a better acceptor than $\mathrm{Nd}$ for soft $\sigma$-donating ligands (by an order of magnitude) according to quantitative ${ }^{1} \mathrm{H}$ NMR studies. Moreover, $\mathrm{Cp} * \mathrm{Al}$ and $\mathrm{Cp}{ }^{*} \mathrm{Ga}$ are both capable of binding $5 f$ over $4 f$ elements with excellent selectivity, which, according to DFT calculations, primarily results from a strong $\sigma$-interaction. These calculations also excluded a stabilization of the $5 f$ electrons (of the $\mathrm{U}$ metal center) through $\pi$-backbonding.

\section{Conclusions and Outlook}

The synthesis of monovalent alanediyls of the type AlR, behaving as excellent $\sigma$-donor properties, has opened the way to the synthesis of a large variety of intermetallic complexes including p-block, d-block and, to a lesser extent thus far, $\mathrm{f}$ block metals. The derived organometallic complexes display a fascinating structural diversity and, in some instances, exhibit unprecedented chemical reactivity due to their interesting bonding properties. In such species, fine tuning of the group 13 metal-bound ligands allow further adjustments of the $\sigma$-donor/ $\pi$-acceptor properties, hence abling the synthesis of novel intermetallic complexes in the near future. In this regard, structurally characterized intermetallic organocompounds incorporating a direct Al-s-block-metal bond, unknown to date, would be of particular interest.

\section{References}

[1] He N, Xie H-B et al. (2007) Organometallics 26:6839

[2] Fedushkin IL, Lukoyanov AN et al (2008) Chem-Eur J 14:8465

[3] Fedushkin IL, Lukoyanov AN et al (2010) Chem-Eur J 16:7563

[4] Bonello O, Jones C et al (2010) Organometallics 29:4914

[5] Wieko M, Roesky PW et al (2007) Chem Commun 927

[6] Liu Y, Li S et al (2011) J Organomet Chem 696:1450

[7] Schumann H, Hummert M et al (2007) Chem-Eur J 13:4216

[8] Fischer RC, Power PP (2010) Chem Rev 110:3877

[9] Macdonald CLB, Cowley AH (1999) J Am Chem Soc 121:12113

[10] Timoshkin AY, Frenking G (2002) J Am Chem Soc 124:7240

[11] Cowley AH (2004) Chem Commun 2369

[12] Uddin J, Boehme C et al (2000) Organometallics 19:571

[13] Uddin J, Frenking G (2001) J Am Chem Soc 123:1683

[14] Gordon JD, Voigt A et al (2000) J Am Chem Soc 122:950

[15] Jutzi P, Neumann B et al (2001) Organometallics 20:2854

[16] Hardman NJ, Power PP et al (2001) Chem Commun 1866

[17] Yang Z, Ma X et al (2005) Angew Chem Int Ed 44:7072

[18] Hardman NJ, Wright RJ et al (2003) J Am Chem Soc 125:2667

[19] Wright RJ, Phillips AD et al (2002) J Am Chem Soc 124:8538 
[20] Frenking G, Fröhlich N. (2000) Chem Rev 100:717

[21] Rayon VM, Frenking G (2002) Chem-Eur J 8:4693-4707

[22] Gorden JD, MacDonald CLB et al (2001) Chem Commun 75

[23] Schulz S, Kuczkowski A et al (2006) Organometallics 25:5487

[24] Lammertsma K, Güner OF et al (1989) Inorg Chem 28:313

[25] Gordon JD, MacDonald CLB et al (2005) Main Group Chem 4:33

[26] Dohmeier C, Robl C et al (1991) Angew Chem Int Ed 30:564

[27] Haaland A, Martinsen K-G et al (1995) Organometallics 14:3116

[28] Loos D, Baum E et al (1997) Angew Chem Int Ed 36:860

[29] Haaland A, Martinsen K-G (1994) Acta Chem Scand 48:172

[30] Beachley OT Jr, Blom R et al (1989) Organometallics 8:346

[31] Romero PE, Piers WE et al (2003) Organometallics 22:1266

[32] Haaland A (1989) Angew Chem Int Ed 28:992

[33] Haaland A (1993) Normal and Dative Bonding in Neutral Aluminum Compounds. In: Robinson GH (ed) Coordination Chemistry of Aluminum, VCH Publishers, Weinheim

[34] Jones AC (1997) Chem Soc Rev 101

[35] Jegier JA, Gladfelter WL (2000) Coord Chem Rev 206-207:631

[36] Carmalt CJ, Basharat S (2007) Precursors to Semiconducting Materials. In: O'Hare D (ed) Comprehensive Organometallic Chemistry III, 12.01:1

[37] Malik MA, Afzaal M et al (2010) Chem Rev 110:4417

[38] Wiberg E, May A. (1955) Z Naturforsch B10:229

[39] Staubitz A, Robertson APM et al (2010) Chem Rev 110:4079

[40] Welch GC, San Juan RR et al (2006) Science 314:1124

[41] Stephan DW, Erker G (2010) Angew Chem Int Ed 49:46

[42] Staubitz A, Robertson APM et al (2010) Chem Rev 110:4023

[43] Romm IP, Noskov YG et al (2007) Rus Chem Bull Internat Ed 56:1935

[44] Schulz S (2003) Adv Organomet Chem 49:225

[45] Spiridonov A, Malkova AS (1969) Zh Strukt Khim 10:33; J Struct Chem USSR 10:303

[46] Coleman AP, Nieuwenhuyzen M et al (1995) Chem Commun 2369

[47] Malkova, AS, Suvorov AV (1969) Russ J Inorg Chem 14:1049

[48] Kutzelnigg W (1984) Angew Chem Int Ed 23:272

[49] Schulz S, Nieger M (1999) Organometallics 18:315

[50] Nieger M, Schulz S Private communication, Cambridge Crystallographic Data Center, CCDC No. 138649

[51] Schulz S, Kuczkowski A et al (2000) J Organomet Chem 604:202

[52] Schulz S, Kuczkowski A et al (2010) J Organomet Chem 695:2281

[53] Schuchmann D, Kuczkowski A et al (2007) Eur J Inorg Chem 931

[54] Kuczkowski A, Schulz S et al (2001) Eur J Inorg Chem 2605

[55] Kuczkowski A, Fahrenholz S et al (2004) Organometallics 23:3615

[56] Kuczkowski A, Heimann S et al (2011) Organometallics 30:4730

[57] Kuczkowski A, Schulz S et al (2001) Organometallics 20:2000

[58] Kuczkowski A, Schulz S et al (2001) Angew Chem Int Ed 40:4222

[59] Kuczkowski A, Schulz S et al (2002) Organometallics 21:1408

[60] Ashe AJ III, Ludwig EG Jr et al (1984) Organometallics 3:337

[61] Mundt O, Riffel H et al (1984) Z Naturforsch 39b:317

[62] Pyykkö P, Atsumi M (2009) Chem-Eur J 15:186

[63] Samaan S (1978) Metallorganische Verbindungen des Arsens, Antimons und Bismuts. In: Houben Weyl, Methoden der Organischen Chemie, 4th edn. Thieme Verlag, Stuttgart

[64] Keys A, Brain PT et al (2008) Dalton Trans 404

[65] Woski M, Mitzel NW (2004) Z Naturforsch 59b:269

[66] Cowley AR, Downs AJ et al (2005) Organometallics 24:5702-57 
[67] The $p$-character of the electron lone pair is expected to increase and the $s$-character of the $\mathrm{Sb}-\mathrm{C}$ and $\mathrm{Sb}-\mathrm{Sb}$ bonding electron pairs to decrease upon complexation, resulting in a widening of the C-Sb-C and C-Sb-Sb bond angles.

[68] Barron AR, Cowley AH et al (1988) Polyhedron 7:77

[69] Cowley AH, Jones RA et al (1988) J Organomet Chem 341:C1

[70] Cowley AH, Jones RA et al (1990) Chem Mater 2:221

[71] Baldwin RA, Foos EE et al (1996) Organometallics 15:5035

[72] Wells RL, Foos EE et al (1997) Organometallics 16:4771

[73] Schulz S, Nieger M. (1998) J Organomet Chem 570:275

[74] Foos EE, Wells RL et al (1999) J. Cluster Sci. 10:121

[75] Foos EE, Jouet RJ et al (1999) J Organomet Chem 582:45

[76] Foos EE, Jouet RJ et al (2000) J Organomet Chem 598:182

[77] Lide DR (1997-1998) CRC Handbook of Chemistry and Physics", 78th edn. CRC Press, New York, 9

[78] Schulz S, Nieger M (1998) Organometallics 17:3398

[79] Schulz S, Kuczkowski A et al (2000) Organometallics 19:699

[80] Schulz S, Nieger M (1999) Angew Chem Int Ed 38:967

[81] Schulz S, Nieger M (2002) Organometallics 21:2793

[82] Matar M, Kuczkowski A et al (2007) Eur J Inorg Chem 2472

[83] Schulz S, Schoop T et al (1995) Angew Chem Int Ed 34:919

[84] Breunig HJ, Stanciu M et al (1998) Z Anorg Allg Chem 624:1965

[85] Thomas F, Schulz S et al (2003) Organometallics 22:3471

[86] Thomas F, Schulz S et al (2003) Angew Chem Int Ed 42:5641

[87] Schulz S, Thomas F et al (2006) J Chem Soc Chem Commun 1860

[88] For most recent reviews on group 13/15 chemistry of the heavier homologues of group 15 see: Schulz, S. (2003) Adv Organomet Chem 49:225; Schulz, S. (2002) Synthesis, Structure and Reactivity of Group 13/15 Compounds containing the heavier Elements of Group 15. In Roesky HW, Atwood DA (eds) Structure and Bonding, Vol. 103: Group 13 Chemistry I: Fundamental New Developments, 117

[89] Schulz S, Kuczkowski A et al unpublished results

[90] Thomas F, Schulz S et al (2002) Z Anorg Allg Chem 628:235

[91] Schulz S, Nieger M (2000) Organometallics 19:2640

[92] Schulz S, Thomas F et al (2000) 19:5758

[93] Thomas F, Schulz S et al (2001) Eur J Inorg Chem 161

[94] Schulz S, Nieger M (2011) J Chem Crystallogr 41:349

[95] Atwood DA, Contreras L (1993) Organometallics 12:17

[96] Janik JF, Wells RL (1998) Inorg Chem 37:3561

[97] Wang Y, Xie Y et al (2004) Science 321:1069

[98] Wang Y, Robinson GH (2011) Inorg Chem 50:12326

[99] Wang Y, Robinson GH (2012) J Chem Soc Dalton Trans 41:337

[100] Wang Y, Robinson GH (2009) Chem Commun 5201

[101] Vogel U, Timoshkin AY et al (2001) Angew Chem Int Ed 40:4409

[102] Thomas F, Schulz S et al (2002) Chem-Eur J 8:1915

[103] Thomas F, Schulz S et al (2001) Organometallics 20:2405

[104] Bodner GM, May MP et al (1980) Inorg Chem 19:1951

[105] Tessier-Youngs C, Bueno C et al (1983) Organometallics 7:1054

[106] Veith M, Frank W (1985) Angew Chem Int Ed 24:223

[107] Veith M, Recktenwald O (1982) Top Curr Chem 104:1-55, Springer Verlag, New York

[108] Cowley AH, Jones RA et al (1991) Angew Chem Int Ed 30:1143

[109] Harlan CJ, Gillan EG (1996) Organometallics 15:5479

[110] Cui C, Roesky HW et al (1999) Organometallics 18:5120

[111] Cui C, Roesky HW et al (2000) Inorg Chem 39:3678

[112] Klimek KS, Proust J et al (2001) Organometallics 20:2047 
[113] Zheng W, Mösch-Zanetti NC et al (2000) Angew Chem Int Ed 39:4276

[114] Jancik V, Moya Cabrera MM (2004) Eur J Inorg Chem 3508

[115] Gardiner MG, Raston CL et al (1995) J Chem Soc Chem Commun 2501

[116] Schulz S, Roesky HW et al (1993) Angew Chem Int Ed 32:1729

[117] Uhl W, Schütz U (1994) Z Naturforsch 49b:931

[118] Barden CJ, Charbonneau P et al (2002) Organometallics 21:3605

[119] Godfrey PD, Raston CL et al (1997) Chem Commun 2235

[120] Gardiner MG, Raston CL et al (1995) J Chem Soc Chem Commun 1457

[121] See the following and references cited therein: Kuchta MC, Parkin G (1998) Coord Chem Rew 176:323

[122] Gillan EG Barron AR (1997) Chem Mater 9:3037

[123] Garje SS, Copsey MC et al (2006) J Mater Chem 16:4542

[124] Corradine P, Sirrigu A (1967) Inorg Chem 6:601

[125] Schwarzhans E, Steiger H (1972) Angew Chem Int Ed 11:535

[126] Kroll WR, McVicker GB (1971) J Chem Soc D 591

[127] Schrieke RR, Smith JD (1971) J Organomet Chem 31:C46

[128] Tebbe FN, Guggenberger LJ (1973) J Chem Soc Chem Commun 227

[129] Schneider JJ, Denninger U et al (1994) Z Naturforsch 49b:1549

[130] Conway AJ, Gainsford GJ et al (1975) J Chem Soc Dalton Trans 2499

[131] Gainsford GJ, Schrieke RR et al (1972) J Chem Soc Chem Commun 650

[132] Su J, Li X-W et al (1997) Organometallics 16:4511

[133] Cotton FA, Feng X (1998) Organometallics 17:128

[134] Dagani R (1998) Chem Eng News 76:31

[135] Steinke T, Gemel C et al (2004) Angew Chem Int Ed 43:2999

[136] Steinke T, Cokoja M et al (2005) Angew Chem Int Ed 44:2943

[137] Cadenberg T, Gemel C et al (2005) J Am Chem Soc 127:17068

[138] Fischer RA, Miehr A (1996) Chem Mater 8:497

[139] Cokoja M, Parala H et al (2006) Chem Mater 18:1634

[140] Cokoja M, Jagirdar BR et al (2008) Eur J Inorg Chem 3330

[141] Cokoja M, Parala H et al (2007) Chem Mater 19:5721

[142] Fischer RA, Weiß J (1999) Angew Chem Int Ed 38:2830

[143] Linti G, Schnöckel H (2000) Coord Chem Rev 206-207:285

[144] Gemel C, Steinke T et al (2004) Eur J Inorg Chem 4161

[145] Marciniec B, Pawluc P et al (2007) Inorganometallic Chemistry. In: Bertini E (ed) Inorganic and Bio-Inorganic Chemistry, Vol. 1, Encyclopedia of Life Support Systems (EOLSS), Developed under the Auspices of the UNESCO, Eolss Publishers, Oxford, UK, [http://www.eolss.net] [Retrieved September 7, 2011], pp $239 \mathrm{ff}$.

[146] Bollermann T, Cadenbach et al (2011) Inorg Chem 50:5808

[147] Burlitch JM, Leonowicz ME et al (1979) Inorg Chem 18:1097

[148] Golden JT, Peterson TH et al (1998) J Am Chem Soc 120:223

[149] Braunschweig H, Gruss K et al (2007) Angew Chem Int Ed 46:7782

[150] Amgoune A, Bourissou D (2011) J Chem Soc Chem Commun 47:859

[151] Braunschweig H, Müller J et al (1996) Inorg Chem 35:7443

[152] Weiß J, Stetzkamp D et al (1997) Angew Chem Int Ed 36:70

[153] Fölsing H, Segnitz O et al (2000) J Organomet Chem 606:132

[154] Anand BN, Krossing I et al (1997) Inorg Chem 36:1979

[155] Stender M, Oesen H et al (2001) Z Anorg Allg Chem 627:980

[156] Dohmeier C, Krautscheid H (1994) Angew Chem Int Ed 33: 2482

[157] Üffing C, Ecker A et al (1998) Organometallics 17:2373

[158] Yu Q, Purath A et al (1999) J Organomet Chem 584:94

[159] Weiß D, Steinke T et al (2000) Organometallics 19:4583

[160] Steinke G, Gemel C et al (2005) Chem-Eur J 11:1636

[161] Buchin B, Steinke T et al (2005) Z Anorg Allg Chem 631:2756 
[162] Kempter A, Gemel C et al (2006) Chem Commun 1551

[163] Kempter A, Gemel C et al (2007) Chem-Eur J 13:2990

[164] Schneider JJ, Krüger C (1994) Angew Chem Int Ed 33: 2435

[165] Noor A, Glatz G et al (2009) Nature Chem 1:322

[166] Fischer RA, Schulte MM et al (1998) J Am Chem Soc 120:1237

[167] Fischer RA, Priermeier T (1994) Organometallics 13:4306

[168] Forder RA, Prout K (1974) Acta Cryst B30:2312

[169] Rettig SJ, Storr A et al (1974) Acta Cryst B30:666

[170] Tsukamoto S, Sakaki S (2011) J Phys Chem A 115:8520

[171] Cadenbach T, Gemel C et al (2004) J Chem Soc Dalton Trans 3171

[172] Doerr M, Frenking G (2002) Z Anorg Allg Chem 628:843

[173] Coombs ND, Clegg W et al (2008) J Am Chem Soc 130:5449

[174] Vidovic D, Aldridge S (2011) Chem Sci 2:601

[175] Pandey KK, Braunschweig H et al (2011) Inorg Chem 50:1402

[176] Pandey KK, Aldridge S (2011) Inorg Chem 50:1798

[177] Liddle ST (2009) Proc R Soc A 465, 1673

[178] Roesky PW (2009) J Chem Soc Dalton Trans 1887

[179] Gamer MT, Roesky PW et al (2006) Angew Chem Int Ed 45:4447

[180] Wiecko M, Roesky PW (2007) Organometallics 26:4846

[181] Arnold PL. Liddle ST et al (2007) J Am Chem Soc 129:5360

[182] Jones C, Stasch A et al (2009) J Chem Soc Chem Commun 113

[183] Krinsky JL, Minasian SG et al (2011) Inorg Chem 50:345

[184] Minasian SG, Krinsky JL et al (2008) J Am Chem Soc 130:10086

[185] Minasian SG, Krinsky JL et al (2009) J Am Chem Soc 131:13767

[186] Liddle ST, McMaster J et al (2009) Angew Chem Int Ed 48:1077 


\section{DuEPublico}

This text is made available via DuEPublico, the institutional repository of the University of Duisburg-Essen. This version may eventually differ from another version distributed by a commercial publisher.

DOI: 10.1007/3418_2012_33

URN: urn:nbn:de:hbz:464-20201116-090355-6

This is a post-peer-review, pre-copyedit version of an article published in:

Woodward S., Dagorne S. (eds) Modern Organoaluminum Reagents.

Topics in Organometallic Chemistry, vol 41. Springer, Berlin, Heidelberg, 2013, pp 59-90.

The final authenticated version is available online at: https://doi.org/10.1007/3418_2012_33

All rights reserved. 